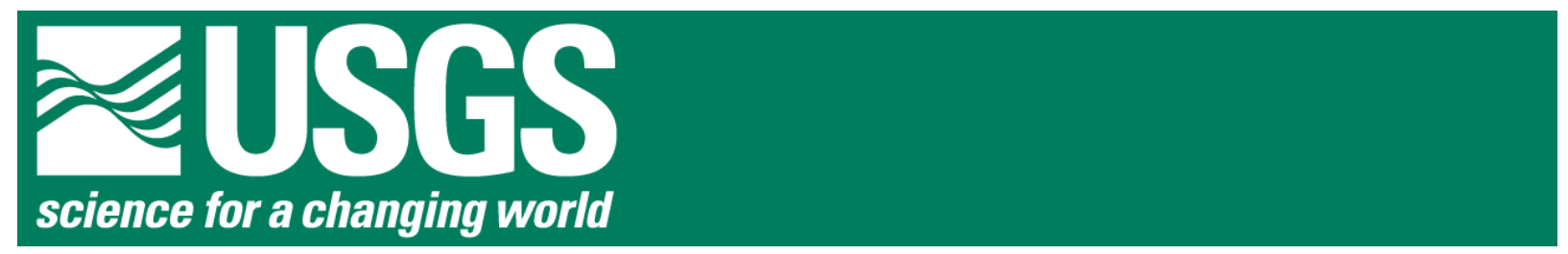

Coastal Circulation and Potential Coral-larval Dispersal in Maunalua Bay, O‘ahu, HawaiiMeasurements of Waves, Currents, Temperature, and Salinity, June-September 2010

By M. Katherine Presto, Curt D. Storlazzi, Joshua B. Logan, Thomas E. Reiss, and Kurt J. Rosenberger

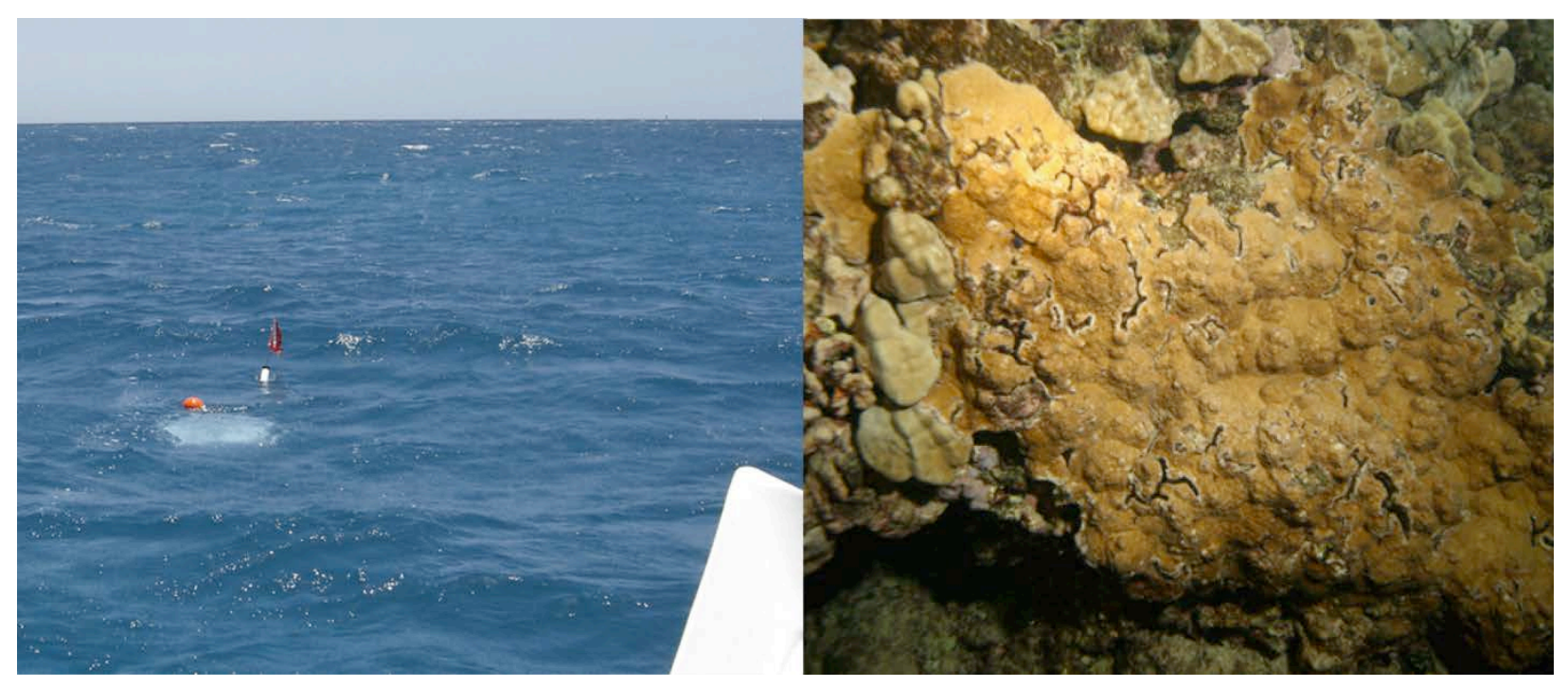

Open-File Report 2012-1040

U.S. Department of the Interior

U.S. Geological Survey 
This page intentionally left blank 


\section{U.S. Department of the Interior \\ KEN SALAZAR, Secretary}

\section{U.S. Geological Survey \\ Marcia K. McNutt, Director}

U.S. Geological Survey, Reston, Virginia: 2012

For product and ordering information:

World Wide Web: http://www.usgs.gov/pubprod

Telephone: 1-888-ASK-USGS

For more information on the USGS—-the Federal source for science about the Earth, its natural and living resources, natural hazards, and the environment:

World Wide Web: http://www.usgs.gov

Telephone: 1-888-ASK-USGS

Any use of trade, product, or firm names is for descriptive purposes only and does not imply endorsement by the U.S. Government.

Although this report is in the public domain, permission must be secured from the individual copyright owners to reproduce any copyrighted material contained within this report.

Suggested citation:

Presto, M.K., Storlazzi, C.D., Logan, J.B., Reiss, T.E., and Rosenberger, K.J., 2012, Coastal circulation and potential coral-larval dispersal in Maunalua Bay, O`ahu, Hawaii-Measurements of waves, currents, temperature, and salinity, June-September 2010: U.S. Geological Survey Open-File Report 2012-1040, 67 p., available at $h$ ttp://pubs.usgs.gov/of/2012/1040/.

COVER

Left: Ph/oto of satellite-tracked Lagrangian surface drifter deployed in Maunalua Bay, O‘ahu Right: Photo of Montipora Capitata, the coral studied in Maunalua Bay during its spawning season 


\section{Contents}

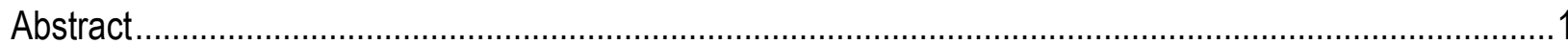

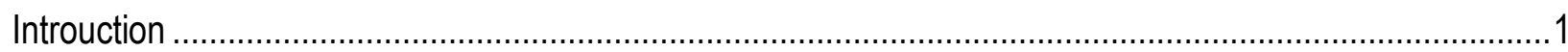

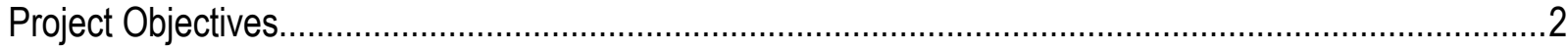

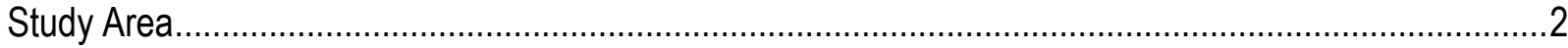

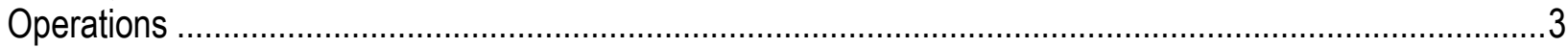

Research Platform and Field Operations......................................................................................

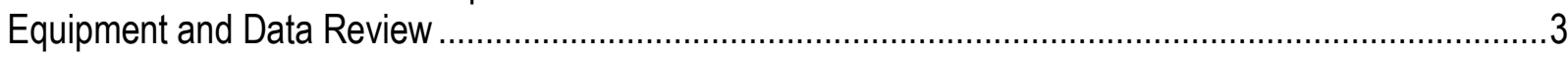

Data Acquisition and Quality .............................................................................................

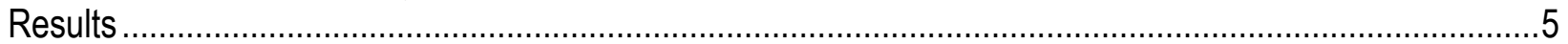

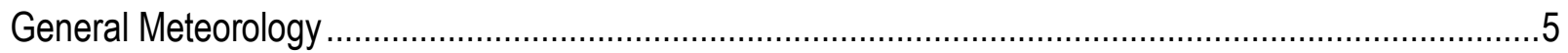

Tides

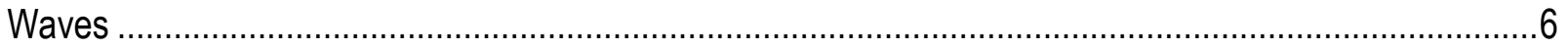

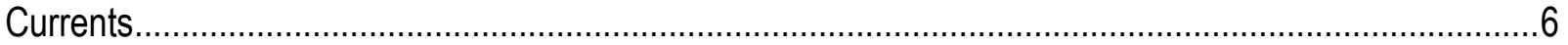

Temporal Variations of Water-column Properties .............................................................................

Spatial Variations in Water-column Properties ...............................................................................

Spatial Variations in Currents ...................................................................................................

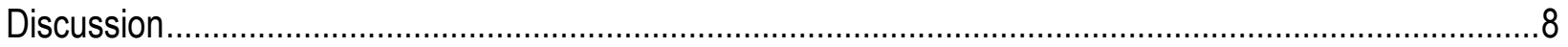

Meteorologic and Oceanographic Forcing During the 2010 Summer Coral-Spawning Season...................8

Temporal and Spatial Variability in Temperature and Salinity During the 2010 Summer Coral-

Spawning Season ...............................................................................................................

Circulation and Potential Coral-larval Dispersal During the 2010 Summer Coral-Spawning Season .........9

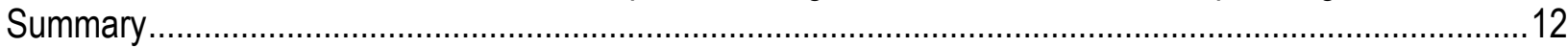

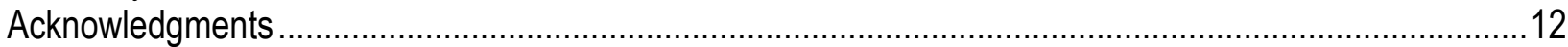

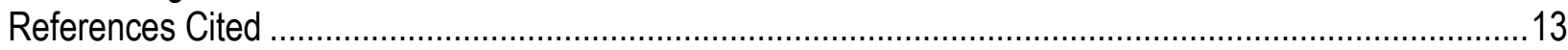

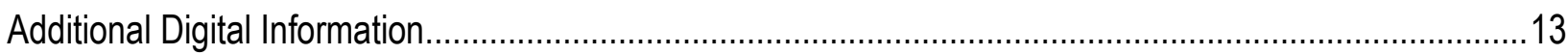

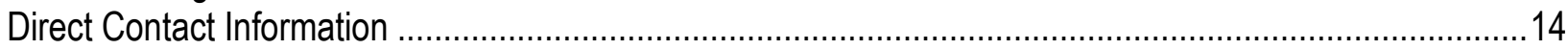

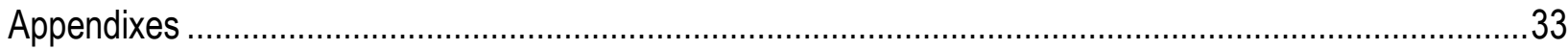

Appendix 1. Acoustic Doppler Current Profiler (ADCP) Information ...................................................33

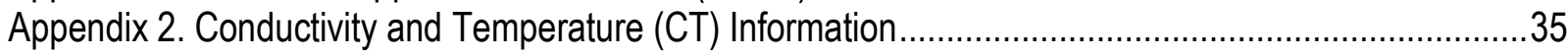

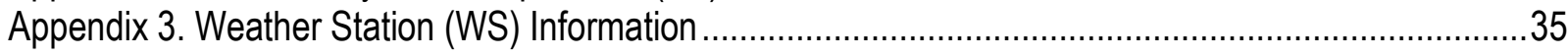

Appendix 4. Water-Column Profiler (WCP) Information....................................................................... 35

Appendix 5. Water-Column Profiler (WCP) log, June 2010 ….....................................................36

Appendix 6. Time-series Plots of Variations in Water Level, Wave Heights, Wave Periods, and Wave

Directions from Acoustic Doppler Current Profilers (ADCPs) in Maunalua Bay for 2010 Year

Days 170-250 (June 19-September 7) ................................................................................

Appendix 7. Time-Series Plots of Variations In Water Level, Currents, and Temperature from

Acoustic Doppler Current Profilers (ADCPs) in Maunalua Bay for 2010 Year Days 170-250

(June 19-September 7)

Appendix 8. Time-Series Plots of Variations in Temperature and Salinity from

Conductivity/Temperature (CT) Sensors in Maunalua Bay for 2010 Year Days 170-250 (June

19-September 7)

Appendix 9. Maps Showing the Spatial Variability in Temperature and Salinity from Water-Column

Profiler (WCP) Casts in Maunalua Bay.... 
Appendix 10. Maps Showing the Spatial Variability in Near-Surface Current Speeds and Directions from Vessel-Mounted Acoustic Doppler Current-profiler (VM-ADCP) Surveys in Maunalua Bay ...... 58 Appendix 11. Maps and Time-Series Plots of Lagrangian Surface-Drifter Deployments in Maunalua

Bay 62

\section{Figures}

1. A, Aerial photograph and scanning hydrographic operational airborne lidar surveys (SHOALS) bathymetric map of Maunalua Bay and its location on O'ahu, Hawaii. Also shown are the location of instrument packages and major landmarks. $B$, Vessel-mounted acoustic Doppler current-profiler (VM-ADCP) tracklines and water-column Profiler (WCP) cast locations are denoted by italic white numbers and numbers in dots, respectively.

2. $A-C$, Photographs of the equipment used in Maunalua Bay during the 2010 summer experiment. $A$, Underwater photograph of a MiniProbe with an acoustic Doppler current profiler (ADCP) and a conductivity and temperature (CT) sensor along the 10-m isobath at the Paikō 10-m site. $B$, Watercolumn Profiler (WCP). C, Example of a Lagrangian surface drifter in the ocean taken from the R/V Alyce C. D, Example of the coral, Montipora capitata, the spawning of which was the focus of the 2010 summer experiment.

3. Time-series plot of meteorologic and oceanographic forcing in Maunalua Bay during the 2010 summer experiment. $A$, Barometric pressure, in millibars. $B$, Air temperature, in degrees Celsius. $C$, Wind speed, in meters per seconds, with average wind speed in blue and peak wind speed in red. $D$, Wind speed and direction, in meters per second from true north. $E$, Half-hour rainfall (blue) and cumulative rainfall (red), in millimeters. F, Tidal height, in meters. G, Average (blue) and peak (red) wave height, in meters.

4. Map showing the mean (blue vectors) and variability (red ellipses) in wave heights and directions, in meters from true north, in Maunalua Bay during the 2010 summer experiment for the Diamond Head 20-m, Wailupe 20-m, and Paikō 10-m sites.

5. Map showing the mean (vectors) and variability (ellipses) in current speeds and directions, in meters per second from true north, in Maunalua Bay for the 2010 summer experiment.

6. Scatter plot showing the relationship between water temperature, in degrees Celsius, and salinity, in Practical Salinity Units (PSU) along the cross-shore transect off Paikō from 5-m to 30-m water depth.

7. Map showing the spatial variability in temperature, in degrees Celsius, averaged from water-column Profiler (WCP) surveys in Maunalua Bay made during the June 12-15 (2010 Year Days 162-166) coral-spawning period.. A, Averaged data from $1 \mathrm{~m}$ below the surface. $B$, Averaged data from $1 \mathrm{~m}$ above the seabed. The near-surface temperature data show very uniform temperature throughout the bay, with slightly warmer temperatures close to shore on the western side of the bay.

8. Map showing the spatial variability in salinity, in Practical Salinity Units (PSU), from the watercolumn Profiler (WCP) surveys in Maunalua Bay averaged over the 4 days of the June 12-15 (2010 Year Days 162-166) coral-spawning period. A, Averaged data from $1 \mathrm{~m}$ below the surface. $B$, Averaged data from $1 \mathrm{~m}$ above the seabed. The near-surface salinity was fairly uniform throughout the bay, with the highest salinity values observed close to shore, possibly because of evaporation.

9. Map showing of mean current speeds and directions (arrows) and variability (ellipses), in meters per second from true north, for the vessel-mounted acoustic Doppler current-profiler (VM-ADCP) data from surveys made during the June 12-15 (2010 Year Days 162-166) coral-spawning period, averaged at $400 \mathrm{~m}$ intervals along each VM-ADCP survey line. 
10. Map showing the areal extent of satellite drifters released from 4 locations $(A-D)$ in Maunalua Bay over three nights June 12-15 (2010 Year Days 163-165) in Maunalua Bay following predicted times of coral-spawning in an attempt to track potential coral-larval dispersal. $A$, Inshore location on the east side of the bay near Hawaili Kai harbor. $B$, Mid-shore location on the east side of the bay near Koko Head. C, Inshore location near Wailupe Peninsula. D, Offshore location near Koko Head.

11. Time-series plots showing the vertical variation in acoustic Doppler current profiler (ADCP) acoustic backscatter data before, during, and after the 2010 summer predicted coral-spawning periods in Maunalua Bay and tide data from the Paikō 10-m site. A, Data from the June spawning period (2010 Year Days 162-166). B, Data from the July spawning period (2010 Year Days 191195). C, Data from the August spawning period (2010 Year Days 221-225). D, Data from the September spawning period (2010 Year-Days 250-254).

12. Map showing the areal extent of potential coral-larval dispersal (Storlazzi and others, 2006) from the Diamond Head 20-m (green), Wailupe 20-m (blue), and Paikō 10-m (red) sites during the 2010 summer predicted coral-spawning events in June, July, August, and September in Maunalua Bay. ....32

\section{Tables}

1. Experiment personnel. 15

2.. Instrument package sensors and location information. 15

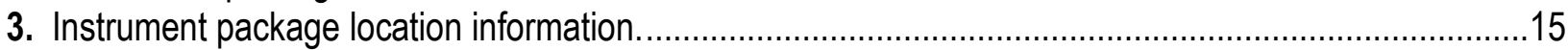

4. Water-column profiler (WCP) cast location and depth information..................................................16

5. Vessel-mounted acoustic Doppler current profiler (VM-ADCP) log information.....................................17

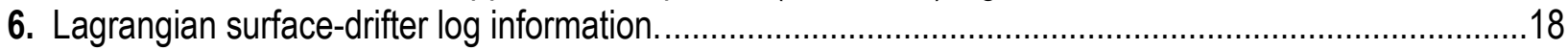

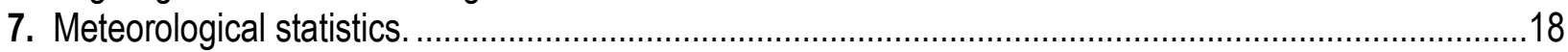

8. Wave statistics.

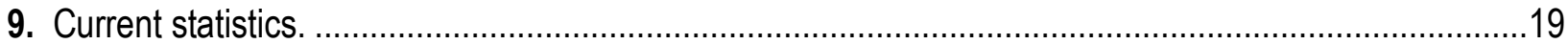

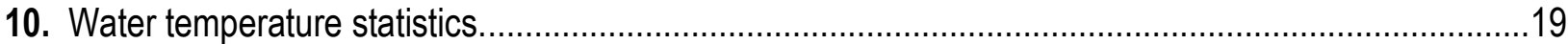

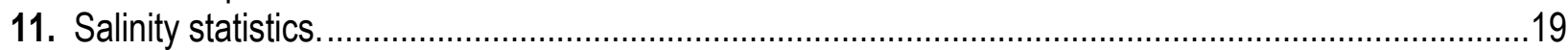

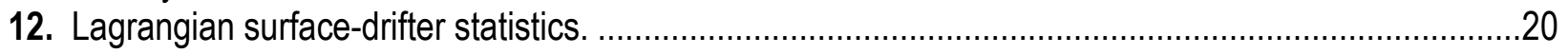




\title{
Coastal Circulation and Potential Coral-larval Dispersal in Maunalua Bay, O‘ahu, Hawaii- Measurements of Waves, Currents, Temperature, and Salinity, June-September 2010
}

\author{
By M. Katherine Presto, Curt D. Storlazzi, Joshua B. Logan, Thomas E. Reiss, and Kurt J. Rosenberger
}

\begin{abstract}
This report presents a summary of fieldwork conducted in Maunalua Bay, O`ahu, Hawaii to address coral-larval dispersal and recruitment from June through September, 2010. The objectives of this study were to understand the temporal and spatial variations in currents, waves, tides, temperature, and salinity in Maunalua Bay during the summer coral-spawning season of Montipora capitata. Short-term vessel surveys and satellite-tracked drifters were deployed to measure currents during the June 2010 spawning event and to supplement the longer-term measurements of currents and water-column properties by fixed, bottom-mounted instruments deployed in Maunalua Bay. These data show that currents at the surface and just below the surface where coral larvae are found are often oriented in opposite directions due primarily to tidal and trade-winds forcing as the primary mechanisms of circulation in the bay. These data extend our understanding of coral-larvae dispersal patterns due to tidal and wind-driven currents and may be applicable to larvae of other Hawaiian corals.
\end{abstract}

\section{Introduction}

Coral recruitment is low in Maunalua Bay, O`ahu, Hawaii, but it is not clear whether this is due to a low supply of coral larvae in the bay or to anthropogenic stressors that impair recruitment success. To help resolve this question, a multi-partner (University of Hawai' $i$, Mālama Maunalua, U.S. Coral Reef Task Force, and the U.S. Geological Survey) experiment investigated coral spawning and larval recruitment during summer 2010 in Maunalua Bay. This study focused on the coral species Montipora capitata, because it is one of the major reef builders along the coastline of the bay and the egg-sperm bundles are large enough (0.95-1.05 $\mathrm{mm}$; Mate and others, 1998) to be seen with the naked eye, allowing visual identification of both the initiation and cessation of spawning. The peak spawning periods for this species are during summer new moons between 20:00 and 22:00 local/Hawaiian Standard Time (HST) (Heyward, 1986; Kolinski and Cox, 2003). In the summer of 2010, this placed the beginning of spawning at or about the evening of Saturday, June 12. Spawning lasted for approximately three to four nights and reoccurred during the new moons in July, August, and September, 2010.

As part of this experiment, the general hydrography and circulation of Maunalua Bay during summer spawning conditions were measured, complementing a dataset collected during the 2008-2009 winter (Storlazzi and others, 2010). This effort included deploying satellite- 
tracked differential Global Positioning System (GPS) drifters in coral larvae slicks to track the movement of the buoyant coral larvae and determine if they were transported into, retained in, or dispersed out of Maunalua Bay. Surveys of currents and water-column properties were conducted before, during, and after the June 2010 spawning event to provide information on the general hydrography of the bay during summer conditions and to identify the presence of eddies or shear zones in the bay that might help to retain larvae, sediment, nutrients, or contaminants. These relatively short-duration vessel surveys were supplemented by longer-term measurements of currents and water-column properties from instruments deployed at a number of fixed stations in the bay from June through September 2010. Both the vessel surveys in June and the longerterm fixed stations deployed from June through September used acoustic Doppler current profilers (ADCPs). The acoustic backscatter data from these instruments have been shown (Storlazzi and others, 2006) to be useful for imaging M. capitata egg-sperm bundles and quantifying the relative intensity of spawning events in Hawaii. Collectively, the combination of mobile vessel surveys and fixed instrument deployments allowed us to determine whether the flow patterns and spawning intensity observed in the intensive June surveys were representative for the full June through September M. capitata spawning season.

\section{Project Objectives}

The objective of this study was to understand the temporal variations in currents, waves, tides, temperature, and salinity in Maunalua Bay during the summer coral-spawning season. To characterize the spatial variability in the physical oceanographic processes surrounding coralspawning sites, three datasets were collected: (1) a vessel-mounted acoustic Doppler current profiler (VM-ADCP) was used to map current velocities throughout the bay during the 4 days following coral-spawning events; (2) vertical profiles of water-column properties, including salinity, temperature, and turbidity, were measured throughout the bay during the same period; and (3) Lagrangian surface drifters were released in Maunalua Bay at night during the coralspawning events to map the potential drift of coral larvae in the initial hours following release into the water column. To place these short-term, spatially distributed measurements into a longer time-scale context, bottom mounted oceanographic instruments were deployed for the 3month period (June-September, 2010) following the spatial surveys. The combination of these spatially and temporally distributed measurements provide insight into the potential fate of terrestrial sediment, nutrient, or contaminant delivery and coral-larval transport within the embayment. Such information is useful for providing baseline information for future watershed decisions and for establishing guidelines for the U.S. Coral Reef Task Force's (USCRTF) Hawaiian Local Action Strategy to address land-based pollution (LAS-LBP) threats to coral reefs in the Maunalua ahupua'a (linked watershed-reef system). These measurements support the ongoing process studies being conducted as part of the U.S. Geological Survey (USGS) Coastal and Marine Geology Program's Pacific Coral Reef Project; the ultimate goal is to better understand the transport mechanisms of sediment, larvae, nutrients, contaminants, and other particles in coral reef settings.

\section{Study Area}

Spatial and temporal measurements of meteorologic and oceanographic data were made during the 2010 summer in Maunalua Bay, on the south side of $O^{`}$ ahu, Hawaii (fig. 1A,B). The bay, which is approximately $10 \mathrm{~km}$ long and $3 \mathrm{~km}$ wide, is flanked by two dormant volcanic craters, Koko Head to the east and Diamond Head to the west. Rainfall in the watersheds that drain into Maunalua Bay, which primarily occurs in the winter months, ranges from more than 
$200 \mathrm{~cm} /$ year at the top of the Ko'olau Range that borders the northwestern part of the bay to less than $70 \mathrm{~cm} /$ year to the east at Koko Head.

\section{Operations}

This section provides information about the personnel, equipment, and field operations used during the study. See table 1 for a list of personnel involved in the experiment and tables 2 through 12 for complete listings of instrument and deployment information and statistical data summaries.

The study used three suites of instruments to provide an integrated understanding of circulation and potential coral-larval dynamics in Maunalua Bay: a weather station, bottommounted time-series oceanographic instrument packages, and spatial oceanographic-survey instruments. The weather station was deployed on top of the Mt. Terrace Condominiums in Hawai'i Kai to quantify meteorologic forcing that might influence circulation and water-column properties in Maunalua Bay. Bottom-mounted oceanographic instrument packages were deployed along the 20-m isobaths at the western (off Diamond Head) and central part of the bay (off the Wailupe Peninsula), as well as in a cross-shore array on the eastern side of the bay off Paikō Lagoon. This cross-shore array included bottom-mounted oceanographic instrument packages on the $10-\mathrm{m}$ and $20-\mathrm{m}$ isobaths and moorings on the $5-\mathrm{m}$ and $30-\mathrm{m}$ isobaths.

In addition to fixed, bottom-mounted, time-series measurements, intensive spatial surveys of currents and water-column properties were made in the bay over a 4-day period, June 12-15, 2010 (2010 Year Days [YD] 163-166), when coral-spawning was predicted to occur (fig. 1B).

All vessel operations involving oceanographic instrumentation and spatial surveys, including mobilization and demobilization, were based out of the Ala Wai Boat Harbor approximately $5 \mathrm{~km}$ to the east of Maunalua Bay, and all instrument packages were situated on the sandy seabed in water depths less than $30 \mathrm{~m}$. Night dives to verify coral spawning were based out of Hawai'i Kai Harbor, located in the northeast corner of Maunalua Bay.

\section{Research Platform and Field Operations}

Instrument deployments and recoveries were conducted using the F/V Alyce C. Watercolumn profiler casts were conducted from the vessel using a hand line. A differential-equipped GPS compass was mounted on the F/V Alyce C. to provide accurate position and heading information for the vessel-mounted current-profiler data-acquisition and processing system. The driver's station was outfitted with a laptop computer and GPS-enabled navigation system to provide the vessel captain with a graphic display of position information, speed, heading, and distance to the next location. The Lagrangian surface drifters were deployed over reefs each night from the D/V Sea Fox, following the predicted coral spawning; the F/V Alyce C. and the $\mathrm{D} / \mathrm{V}$ Leila were used to recover the drifters.

\section{Equipment and Data Review}

Acoustic Doppler Current Profilers-Four upward-looking acoustic Doppler current profilers (ADCP) were mounted on stainless steel platforms called MiniPROBE instrument packages (fig. 2A) along the 10-m and 20-m isobaths in Maunalua Bay. These ADCPs measured currents at $2 \mathrm{~Hz}$ for $150 \mathrm{~s}$ every $5 \mathrm{~min}$, in $1.0-\mathrm{m}$ bins from $1.0 \mathrm{~m}$ above the seabed up to the surface. These data allow calculation of tides $(\mathrm{m})$, mean current speeds $(\mathrm{m} / \mathrm{s})$, mean current directions (degrees true north), and higher frequency motions such as internal tidal bores and nonlinear internal waves. Directional wave data were recorded at $2 \mathrm{~Hz}$ for 1,024 s every 2 hours; these data allow calculation of significant wave height $(\mathrm{m})$, dominant wave period $(\mathrm{s})$, and mean 
wave direction (degrees true north). Acoustic backscatter data (dB) collected from the ADCPs during the current measurements provide information on particulates in the water-column and are used as a qualitative measurement of coral-larvae abundance. Instrument package locations are listed in table 3; complete sensor and processing information is listed in appendix 1.

Conductivity and Temperature Sensors - Six conductivity and temperature (CT) sensors (fig. $2 A$ ) collected and averaged 4 samples every 5 minutes to measure water temperature $\left({ }^{\circ} \mathrm{C}\right)$ and conductivity $(\mathrm{S} / \mathrm{m})$, from which salinity (Practical Salinity Units, PSU) was calculated. The rapid sampling rate was used to facilitate identification of transient freshwater plumes generated by surface runoff and (or) submarine groundwater discharge being advected past the instruments. Two additional conductivity and temperature sensors collected and averaged four samples every 1 minute at the base of the moorings on the 5-m and 30-m isobaths to examine the propagation of internal waves from deeper ocean water into the shallow part of the bay. The sensor locations are listed in table 3; complete sensor and processing information is listed in appendix 2.

Weather Station (WS) - Meteorological data were acquired by a self-contained weather station (WS) deployed on top of the Mt. Terrace Condominiums, approximately $71 \mathrm{~m}$ above sea level, in the northeast corner of the bay (fig. 1A). The WS recorded 25 minutes averages of barometric pressure $(\mathrm{mb})$, air temperature $\left({ }^{\circ} \mathrm{C}\right)$, precipitation $(\mathrm{mm})$, wind speed $(\mathrm{m} / \mathrm{s})$, and wind direction (degrees true north) every 30 minutes. The station location is listed in table 3; complete sensor information is listed in appendix 3.

Water-Column Profiler (WCP) —Depth profiles of water properties were obtained using a water-column profiler (WCP) (fig. 2B) with conductivity, temperature, depth, optical backscatter, light transmission, and chlorophyll sensors. The profile surveys were conducted over 4 days (June 12-15, 2010) between Koko Head and Diamond Head craters at the beginning and end of each vessel-mounted acoustic Doppler current profiler survey line. Profile locations and depth information are listed in table 4; complete sensor information and individual cast acquisition logs are listed in appendixes 4-5.

Vessel-Mounted Acoustic Doppler Current Profiler-Hydrographic surveys of current speeds and directions, along with acoustic backscatter, throughout the water-column were conducted using a downward-looking $600 \mathrm{kHz}$ vessel-mounted acoustic Doppler current profiler (VM-ADCP) mounted to the starboard side of the R/V Alyce C. The data were collected in $1 \mathrm{~m}$ bins from the surface down to the seabed every second and averaged every $30 \mathrm{~s}$. Bottom tracking by the VM-ADCP and a boat-mounted differential GPS (DGPS) and digital compass were used to accurately determine the location, magnitude, and direction of the currents throughout the water-column. Data were collected along approximately 7 cross-shore and 5 alongshore transects between Diamond Head and Koko Head (fig. 1B) each day from June 12 through 15, 2010 (YD 163-166). Both the order and start and end location of each survey transect were reversed each day to minimize the influence of tidal stage and diurnal sea-breeze forcing.

Lagrangian Surface Drifters-Satellite-tracked, DGPS, Lagrangian surface drifters were deployed each night during coral spawning (June 12-15, 2010, YD 163-165) to track surface (1 $\mathrm{m}$ below the surface) currents (fig. $2 C$ ). The drifters logged their location internally every 1 minute and transmitted their positions to Iridium satellites every 5 minutes. Two drifters were released each night, one from the $10 \mathrm{~m}$ MiniProbe site where night dives were conducted to verify spawning of $M$. capitata (fig. $2 D$ ) and the second from a different location in the bay to provide additional spatial information on the surface currents. The drifters were recovered the following day by boat, refurbished, and prepared for release the following evening. 
Miscellaneous Data Sources - Navigation equipment for deployment, recovery, and survey operations included a hand-held wide area augmentation system (WAAS)-equipped DGPS unit and a computer with positioning and mapping software. The positioning and mapping software enabled real-time DGPS position data to be combined with data from previously collected high-resolution scanning hydrographic operational airborne lidar surveys (SHOALS), bathymetry, 5-m isobaths, and aerial photographs.

\section{Data Acquisition and Quality}

Data were acquired for 98 days during the period between June 12 and September 13, 2010 (YD 163-256). More than 2 million data points were recorded by the ADCPs, CTs, and WS; more than 8,000 data points were recorded by the WCP and 0.5 million data points by the VM-ADCP. The raw data were archived, and copies of the data were post-processed for analysis.

The ADCP, CT, and WS data generally appeared to be of high quality. The ADCP at the Wailupe 20-m site had a malfunctioning pressure sensor for the first 60 days, rendering the tide and wave data unusable during that period. The instrument package at the Paiko 20 -m site tilted and was eventually buried by sand at the beginning of the deployment, likely due to strong currents. This rendered the ADCP data unusable and reduced the quality of the CT data at this location. The WCP data were very high in quality, with spurious surface data removed during processing. The VM-ADCP data were also very high in quality, and any spurious data were removed during processing.

\section{Results}

This section reviews the data collected by the instruments during the deployments and addresses the significance of the findings to better understand the oceanographic conditions in the study area.

\section{General Meteorology}

The study period from 2010 YD 163-256 covered the dry, summer, trade-wind season in Hawaii (fig. 3). Precipitation ranged from 0.0 to $2.5 \mathrm{~mm}$, with a mean rainfall \pm one standard deviation of $0.01 \pm 0.1 \mathrm{~mm}$ (fig. $3 E$ ). The greatest amounts of rainfall occurred between days 2010 YD 213-218, days which coincided with low barometric pressure and cooler air temperatures (fig. 3E,F). The air temperature ranged from $21.19^{\circ}$ to $29.19^{\circ} \mathrm{C}$, with a mean temperature \pm one standard deviation of $24.99 \pm 1.55^{\circ} \mathrm{C}$ (fig. $3 B$ ). Daily heating/cooling on the order of 1 to $2^{\circ} \mathrm{C}$ was observed, with a slight warming trend over the course of the deployment. The mean wind speeds at the weather station (WS) ranged from $1.62 \mathrm{~m} / \mathrm{s}$ to $11.81 \mathrm{~m} / \mathrm{s}$ (fig. $3 C$ ), with a mean speed \pm one standard deviation of $6.28 \pm 1.52 \mathrm{~m} / \mathrm{s}$ during the deployment. The mean wind direction \pm one standard deviation during the deployment was $78.69 \pm 10.13^{\circ}$ (table 7 ). Winds mainly from the east were classified as "trade winds" and were associated with dry, stable weather with low rainfall; this type of forcing characterized approximately 90 percent of the study period (fig. $3 C, D)$.

\section{Tides}

The study period encompassed seven complete spring-neap tidal cycles (fig. $3 F$ ). The tides in Maunalua Bay are typical for the Hawaiian Islands: microtidal, mixed, semidiurnal with two uneven high tides and two uneven low tides per day. As a result, the interval between successive low and high tides was just every 6 hours. The mean daily tidal range was 
approximately $0.6 \mathrm{~m}$, whereas the minimum and maximum daily tidal ranges were $0.4 \mathrm{~m}$ and 1.0 $\mathrm{m}$ during neap and spring tides, respectively.

\section{Waves}

Significant wave heights ranged from $0.17 \mathrm{~m}$ at the Paiko $10-\mathrm{m}$ site to $1.91 \mathrm{~m}$ at the Diamond Head 20-m site, with a mean significant height \pm one standard deviation of $0.87 \pm 0.23$ $\mathrm{m}$ for all of the sites (table 8). Dominant wave periods varied from $3.0 \mathrm{~s}$ at Wailupe $20-\mathrm{m}$ site to $14.1 \mathrm{~s}$ at the Diamond Head $20-\mathrm{m}$ site, with a mean dominant period \pm one standard deviation of $6.9 \pm 1.1 \mathrm{~s}$ for all the sites. The mean wave direction \pm one standard deviation for all the sites was $185.1 \pm 15.9^{\circ}$ (table 8 ). The waves measured at all of the sites were consistently from the south, most likely generated by the strong easterly trade winds and refraction into the bay (fig. $3 G$ ). The largest wave heights were measured between 2010 YD 212-218. This wave event was associated with strong winds, rainfall, and cooler temperatures, indicating that the event was most likely generated locally from the passage of a low-pressure system (fig. 3, shaded area). Appendixes 6.1 - 6.3 show all of the time-series wave data for the Diamond Head 20-m, Wailupe 20-m, and Paikō 10-m sites.

\section{Currents}

The mean current speed at the Paikō 10 - $\mathrm{m}$ site was $0.04 \pm 0.06 \mathrm{~m} / \mathrm{s}$ close to the surface and $0.03 \pm 0.03 \mathrm{~m} / \mathrm{s}$ close to the seabed (table 9). The mean current speeds \pm one standard deviation at the Wailupe $20-\mathrm{m}$ and Diamond Head 20 -m sites were $0.08 \pm 0.20 \mathrm{~m} / \mathrm{s}$ close to the surface and $0.05 \pm 0.15 \mathrm{~m} / \mathrm{s}$ close to the seabed (table 9), this was approximately two times greater than those close to the surface at the Paiko 10-m site and approximately four times greater than those near to the bed at the Paikō 10-m site. Appendixes 7.1-7.3 show the time-series data for the Diamond Head 20-m, Wailupe-20 m, and Paikō 10-m sites for near-surface, mid-water-column, and nearseabed currents.

\section{Temporal Variations of Water-column Properties}

The water-column properties that were measured by the CTs included variations in temperature $\left({ }^{\circ} \mathrm{C}\right)$, salinity (PSU). These measurements were made to address the temporal variability in water-column properties during the summer coral-spawning period and to provide additional information about the physical controls on the Maunalua Bay's hydrography.

Temperature-Water temperatures at the monitored sites ranged between $22.96^{\circ}$ and $26.79^{\circ} \mathrm{C}$, with a mean temperature \pm one standard deviation of $25.10 \pm 0.40^{\circ} \mathrm{C}$ (table 10 ), with the coolest temperature measured at the Paiko $30-\mathrm{m}$ site and the warmest temperature measured at the Paiko 5-m site. The daily variations in temperature at all of the sites appear to be controlled by daily insolation-driven heating and cooling of $1-2^{\circ} \mathrm{C}$ (appendixes $8.1 \mathrm{~A}-8.6 \mathrm{~A}$ ). The seasonal signal showed a slight warming trend from June through September. Significant decreases in temperature were observed at the deep $(>20 \mathrm{~m})$ sites, which may be the result of internal waves advecting deeper, cooler water up into the shallow parts of the bay; the occurrence of these features appears to be related to the tidal cycle.

Salinity - Salinity at the monitored sites ranged between 28.22 and 35.82 PSU, with a mean salinity \pm one standard deviation of $34.83 \pm 0.31$ PSU (table 11). The lowest salinity was at the Paiko 10-m site and the highest salinity was at the Paikō 30-m site. The salinity at the sites along the $20-\mathrm{m}$ isobath had fairly constant salinity values of about 35 PSU but showed decreases following periods of rainfall (for example, 2010 YD 210-220), suggesting these sites may be influenced by submarine freshwater discharge (appendixes 8.1B-8.2B). The Paikō 5-m and 10-m sites may be influenced by surface freshwater input from streams and the Hawai' $i$ Kai harbor 
following rainfall, as occurred during 2010 YD 210-220 (appendixes 8.3B-8.4B). The Paikō 30$\mathrm{m}$ site showed intermittent increases in salinity, which may be attributed to internal waves advecting deeper, cooler, more saline water up into the shallow parts of bay; these intermittent increases in salinity coincided with decreases in temperature (appendix 8.6B)

\section{Spatial Variations in Water-column Properties}

Spatial variability of water-column properties in Maunalua Bay were characterized using the WCP on 2010 YD 163-166 (June 12-15, 2010), in conjunction with the VM-ADCP surveys. The WCP casts were conducted at the beginning and end of each line (fig. 1B); the start of the surveys alternated between the western and eastern parts of the bays each day. The mean for the top and bottom $1 \mathrm{~m}$ of the water-column for temperature and salinity, along with the mean and standard deviation for the entire water-column for each day, are shown in appendixes 9.1-9.8. Day-to-day differences in the near-surface and near-seabed temperature data probably are due mostly to the time of day when the water-column was profiled. For instance, the relatively high surface temperature values on 2010 YD 163 (June 12) and 165 (June 14) may simply be because the WCP casts on those days were made later in the day; the slightly higher temperatures at depth, especially in the shallow parts of the bay, may also be because of the timing of sampling during the day (appendixes 9.1-9.4).

Water-column averaged salinity values were relatively consistent across the bay (appendixes 9.5-9.8). The near-surface salinity closer to shore was higher than offshore, possibly owing to evaporation; the near-bed salinity close to shore was also higher than offshore, possibly owing to greater submarine groundwater discharge at depth. An anomalously high salinity $(0.5$ PSU greater than the surrounding points) was measured off Hawai' $i$ Kai harbor (appendixes 9.5A, $B-9.7 A, B)$; later, the salinity off Hawai' $i$ Kai harbor was almost 0.5 PSU lower than the surrounding sites (appendixes 9.8A, B). The great variation at this site was most likely caused by tidal exchange and freshwater runoff from the Hawai' $i$ Kai harbor.

\section{Spatial Variations in Currents}

VM-ADCP Surveys-The daily VM-ADCP surveys are shown in appendix 10, and the times that each transect was surveyed are presented in table 5. Appendix 10.1 shows the nearsurface current speeds and directions on 2010 YD 163 (June 12). The survey started in the east side of the bay during a flooding tide. The currents were mainly to the east in the eastern side of the bay and shifted to the west near the middle part of the bay later in the day (appendix 10.1). The currents were strongest at the outer parts of the bay and weaker and more variable closer to shore. Appendix 10.2 shows near-surface current speeds and directions on 2010 YD 164 (June 13); the currents began at the western side of the bay and continued east during a flood tide. The currents were consistently to the east and strongest offshore, with more variable currents close to shore near the Hawai'i Kai harbor. The third day of surveys (2010 YD 165 [June 14]) started from the east side of the bay during slack to flooding tide (appendix 10.3). The currents on the eastern side of the bay were strongly to the east up to VM-ADCP survey line 12 (fig. $1 B$ ), with a transition at line 13, where the currents were strongly to the west for the rest of the survey. The fourth survey (2010 YD 166 [June 15]) began from the west side of the bay during slack low tide, as shown in appendix 10.4. The currents were consistently from the west throughout the bay and more variable closer to shore.

Lagrangian Surface Drifters-Lagrangian surface drifters were deployed over three nights (2010 YD 163-165 [June 12-15]) in Maunalua Bay following the predicted times of coral-spawning in an attempt to track potential coral-larval dispersal. The start and stop dates, 
times, and locations of each drifter are listed in table 6. The drifters were designed so that they floated with the currents $1 \mathrm{~m}$ below the surface. Appendixes 11.1-11 .6 show the nightly drifter release and recovery locations, as well as timelines showing drifter velocity and direction through each deployment. Each plot also shows the wind velocity and the tidal regime during the deployment, with the gray shaded regions denoting nighttime. Statistics for the drifter deployments are shown in table 12 . The drifters travelled primarily to the west after being released, but were influenced by both tidal and wind forcing. A maximum velocity of $1.09 \mathrm{~m} / \mathrm{s}$ was measured by a drifter released at location B; this drifter also travelled the greatest net and total distance. The drifter released at location $\mathrm{D}$ travelled the least net distance, as it was caught in a series of small (on the order of $\sim 100 \mathrm{~m}$ ) eddies propagating back and forth around Koko Head.

\section{Discussion}

\section{Meteorologic and Oceanographic Forcing During the 2010 Summer Coral-Spawning Season}

The deployment in Maunalua Bay took place from June to September 2010 during the summer trade-wind season in Hawaii, which is characterized by consistent winds from the northeast, minimal rainfall, and predominately southerly swells (fig. 3). Trade-wind conditions during this time period are defined as wind speeds greater than $4 \mathrm{~m} / \mathrm{s}$ and wind directions between $45^{\circ}$ and $135^{\circ}$; these conditions generally occur 90 percent of the time. The wave climate for the summer months is marked by trade-wind waves of less than $1 \mathrm{~m}$ and 5-7 s periods (Moberly and Chamberlain, 1964) with occasional larger and longer period swell from the south. Vectors showing the mean wave height and direction during the deployment for the Diamond Head 20-m, Wailupe 20-m, and Paikō 10-m sites are shown in figure 4. The waves impacting Maunalua Bay came primarily from the south, with small variations in direction owing to refraction of the trade-wind waves. The waves were largest in the central part of the bay at the Wailupe 20-m site because of the greater exposure of this site compared to the other sites (appendix 6.1). The smallest waves were measured at the Paikō 1-m site, which is relatively protected in the lee of Koko Head (appendix 6.3). Wave height and directions for the June 2010 experiment were consistent with the wave heights and directions measured between November 2008 and February 2009 (Storlazzi and others, 2010).

The currents during the summer coral-spawning season were influenced by the dominant trade-wind conditions that occurred throughout the experiment. The mean near-surface and nearseabed current speeds and directions are shown in figure 5 for the three primary study sites off Diamond Head, Wailupe, and Paikō. The currents measured during this experiment were consistent in speed and direction with currents measured previously in the area under trade-wind forcing (Storlazzi and others, 2010). The fastest currents near the surface and near the seabed were measured at the Wailupe 20-m site because of its exposure to trade winds; the strong wind forcing at this location resulted in currents directed primarily to the west. The strong offshore currents measured at the Diamond Head 20-m site may result from the bathymetry at the site as well as the topographical steering of the trade winds by Diamond Head crater. The current directions in the eastern, inner part of Maunalua Bay at the Paiko 10-m site were to the east and were weaker than currents measured in other parts of the bay. The weaker, easterly directed currents may be influenced by a circulation eddy created by flow around Koko Head (Storlazzi and others, 2010). 


\section{Temporal and Spatial Variability in Temperature and Salinity During the 2010 Summer Coral- Spawning Season}

The cross-shore array of temperature and salinity sensors near the seabed in the eastern part of Maunalua Bay provided temporal information on the influence of freshwater and the transport of colder, more saline water into shallower areas (fig. 6). The two shallowest locations (Paikō 5-m and 10-m sites) show the greatest influence by freshwater. At the nearshore Paikō 5$\mathrm{m}$ site, daily heating and cooling of the water by insolation with fairly constant salinity was observed. The salinity intermittently decreased 1-2 PSU, which could be attributed to freshwater inputs either from surface runoff mixing into the water-column or submarine groundwater. The Paikō 10-m site shows more regular and substantial decreases in salinity, which may be attributed to pulses of submarine groundwater discharge like those observed in a previous experiment in 2008-2009 (Storlazzi and others, 2010). The Paikō 20-m site shows a smaller decrease in salinity caused by inputs from freshwater sources but shows a slight trend of inputs of cooler, higher salinity water. This pattern may indicate the transport of deeper ocean water up into the shallower depths, potentially by internal waves. The temperature and salinity patterns at the $30 \mathrm{~m}$ mooring also show higher salinity and lower temperatures that may be attributed to internal waves advecting colder, saltier water from deeper offshore into the study area.

Figure 7 shows the mean temperature and variability near the surface and near the seabed during the 4 days of vessel surveys. Overall, near-surface temperatures were fairly constant throughout the bay, with slightly warmer temperatures closer to shore in the western part of the bay (fig. 7A). The temperatures close to the seabed were also fairly constant throughout the bay, except close to shore on the eastern side of the bay. The lower temperatures near the seabed may have been a result of submarine groundwater discharge in this area. In general, the temperature near the surface was higher than the near-seabed values, likely because of insolation. Figure 8 shows the mean salinity and variability near the surface and near the seabed during the 4 days of vessel surveys. The salinity data near the surface was higher close to shore and most variable near Hawai'i Kai harbor (fig. 8A). The salinity data near the seabed also were lower offshore, with the highest salinity values and variability near Hawai' $i$ Kai harbor (fig. 8B). Overall, the vertical salinity stratification was small, and for the most part, the salinity was fairly consistent throughout the bay.

\section{Circulation and Potential Coral-larval Dispersal During the 2010 Summer Coral-Spawning Season}

M. capitata spawning events were predicted to occur every 28 days for approximately 5 days between 20:00 and 22:00 HST during the summer months of June, July, August, and September. Understanding the meteorological (wind) and oceanographic (wave, current, and tidal) forcing during these times was important for predicting the transport and ultimate fate of the coral larvae in Maunalua Bay. The winds were, on average, from the northeast at approximately $6 \mathrm{~m} / \mathrm{s}$ during the four 2010 summer spawning events. These events were also marked by relatively stable barometric pressure, diurnal insolation-driven heating and cooling, and little to no rainfall. The tidal regime during the coral-spawning was spring tides, transitioning to neap tides. The wave climate during the four 2010 summer spawning events was characterized by trade-wind generated waves, with wave heights averaging $0.65 \mathrm{~m}$ with $6.5 \mathrm{~s}$ periods, out of the southeast in Maunalua Bay.

To better understand the overall trend in near-surface currents during the 4-day study period, 2010 YD 163-166 (June 12-15), it was necessary to reduce the potential bias introduced by tidal, wind, and wave forcing. This was accomplished by averaging the VM-ADCP data at 
400-m intervals along each VM-ADCP survey line (fig. 1B). The resulting mean near-surface (2 $\mathrm{m}$ below the surface) currents are shown in figure 9 . The predominant near-surface current direction for the 4-day period was to the east for most of the bay. The near-surface currents closest to shore were weaker and more variable than the near-surface currents in the middle of the bay and offshore. At a depth of $2 \mathrm{~m}$, the effect of the easterly trade winds on the currents was reduced such that the currents shown in figure 9 are more likely a result of the tidal asymmetry in Maunalua Bay than the influence of the trade winds. Consequentially, the potential transport of coral larvae during the June coral-spawning event by currents $2 \mathrm{~m}$ below the surface was mainly to the east. The data from the 4-day study period indicates coral larvae released in the bay may be transported to the east by near-surface currents ( $2 \mathrm{~m}$ below the surface). Coral larvae released close to shore would have a longer residence (flushing) time due to the weak currents, compared to offshore where the faster currents would result in shorter residence times (fig. 9).

The Lagrangian surface drifters provided information on the currents $1 \mathrm{~m}$ below the surface and thus differed from the VM-ADCP survey data (fig. 10) that measured the currents 2 $\mathrm{m}$ below the surface. The majority of the drifters released over reefs following the predicted period of coral-spawning each night travelled downwind to the west and were influenced more by tidal currents during the initial hours of dispersal at night when the wind speeds were lowest (appendix 11.1-11.6). The areal extent of the regions occupied by the drifters are shown in figure 10. The two drifters released close to shore in the eastern and central parts of Maunalua Bay (fig. $10 A, C)$ travelled primarily to the west and stayed close to shore. The drifter released in the eastern part of Maunalua Bay just to the west of Koko Head (fig. 10C) travelled offshore and ultimately to the west. The drifter that was released south of Koko Head and initially travelled eastwards towards Hanauma Bay was trapped in an eddy that was on the order of $100 \mathrm{~m}$ across. As the tide changed and wind speeds increased, this drifter was then advected back into Maunalua Bay by tidal- and wind-driven currents.

Acoustic backscatter from $600-\mathrm{kHz}$ ADCPs can provide a semiquantitative measure of $M$. capitata coral larvae in the water-column during spawning events (Storlazzi and others, 2006). The Paikō 10-m site was situated in an area of $M$. capitata colonies that were predicted to spawn during the 2010 summer months. Figure 11 shows 7-day periods centered on the 2010 predicted 5-day coral-spawning events in June, July, August, and September. Warmer colors in each plot are areas of higher backscatter that indicate greater concentrations of particles (such as sediment or coral larvae) in the water column that scatter the acoustic signals emitted from the ADCP. Because coral egg-sperm bundles are positively buoyant and float to the surface, the presence of elevated backscatter high in the water column during the 5-day spawning periods is likely an indication of the presence of coral larvae. Although it is known that some of the backscatter was caused by coral larvae in the water-column, it is not possible at this time to distinguish the larvae from other material suspended in the water column (fig. 11). With this understanding, the backscatter data provide a semiquantitative measurement that confirms the presence of coral larvae during the four 2010 summer spawning periods and allows analyses of potential coral-larval dispersal using surface current speeds and directions provided by the ADCPs.

Based on the currents and acoustic backscatter measured throughout the water column at three locations during the four summer 2010 predicted coral-spawning events, the areal extent of potential coral-larval dispersal for these time periods can be calculated using the method of Storlazzi and others (2006), which is described below. For the purpose of these calculations, current velocities and directions are assumed to be homogeneous throughout the study area. This 
assumption provides an adequate basis for calculation of the relative direction and magnitude of flow during the projected time period if forcing mechanisms (wind and tides) remain uniform over the projected travel path. The areal extent of potential coral-larval dispersal over a 96-hour period from the three observation sites (Diamond Head, Wailupe, and Paikō) is shown in figure 12. The smallest area of potential coral-larval dispersal was at the Paikō $10-\mathrm{m}$ site in the northeastern part of the bay because of slower currents resulting from less wind-driven forcing in the lee of Koko Head; this area may also be affected by an eddy that was suggested by Storlazzi and others (2010). Data from the Wailupe 20-m site showed the greatest areal extent of potential coral-larval dispersal because of the presence of fast wind-driven currents to the west during periods of predicted coral-spawning. This area of the bay experiences fast current speeds (maximum speeds of $1 \mathrm{~m} / \mathrm{s}$ ) to the west, because trade winds are uninhibited by any topographic highs. The areal extent of potential coral-larval dispersal at the Diamond Head 20-m site was also smaller than the middle of the bay off Wailupe and showed potential dispersal offshore to the south. This may have been a result of the steep gradient in bathymetry offshore and topographic steering of the trade winds offshore from Diamond Head crater.

The mean VM-ADCP data (fig. 9), Lagrangian surface drifter data (fig. 10), and potential coral-larval dispersal pathways calculated from the ADCP data (fig. 12) together suggest that material is transported at different speeds and directions from different depths and locations in Maunalua Bay during the summer coral-spawning period. At the surface, there appears to be two different transport patterns related to the relatively strong trade-wind forcing that is characteristic of the Hawaiian Islands in the summer. Most of the surface waters in the central and western parts of Maunalua Bay are rapidly transported downwind to the west during the daytime when insolation-driven sea breezes contribute to strong wind forcing, resulting in relatively short water residence times of water and surface material. During the night, however, the surface currents in the bay follow the tidal currents, which during and just following the $2010 \mathrm{M}$. capitata spawning periods were toward the east. In contrast to the majority of the bay, the current field in the lee of Koko Head appears to be protected from strong trade-wind forcing. Currents flowing around Koko Head, combined with high cross-shore velocity shear (as seen in fig. 9), appear to generate small-scale eddies that cause relatively long residence times of water and surface material during both the daytime and nighttime. In general, currents a few meters below the surface are faster farther offshore than closer to shore, likely because of the greater height of the water column relative to the hydrodynamic roughness of the coral reefs and seabed. Close to shore, the current flow a few meters below the surface varies substantially along Maunalua Bay. Off Koko Head and Diamond Head, the mean currents are faster near shore $(\sim 10 \mathrm{~cm} / \mathrm{s})$ than in the middle of the bay, where mean currents are weaker $(\sim 1 \mathrm{~cm} / \mathrm{s})$. The faster currents are likely caused by flow constriction and acceleration around these headlands. These observations suggest that water residence times are much shorter in the deep, middle part of the bay and off Diamond Head and Koko Head, and much longer in the shallows $(<10-\mathrm{m}$ depth) along the upper fore reef of the fringing reef between Wailupe and Hawai'i Kai.

The meteorologic and oceanographic data from both this study and previous investigations (Storlazzi and others, 2010) show that flow in Maunalua Bay during small wave conditions is primarily controlled by the winds and tides. The general flow patterns and seawater properties show greater consistency during the summer months, when the forcing by northeast trade winds is relatively steady, storms are infrequent, and nearshore surface-wave-induced flows are at a minimum. During both the initial, intensive survey period (2010 YD 163-166) and the summer coral-spawning season (June-September), both the forcing (winds and tides) and the 
resulting flow and environmental patterns were relatively consistent, with northeast-southwest oscillating tidal currents having a superimposed net flow to the southwest and offshore, consistent with previous datasets (Storlazzi and others, 2010). Similar wind forcing and flow response across multiple spawning periods resulted in comparable models of projected water and coral-larvae dispersal pathways during the 2010 spawning season. Because $M$. capitata always spawns during the nights following a new moon, these spawning events occur during the transition from spring to neap tides, and thus the relative magnitude of the tidal-current forcing during each spawning period is relatively consistent. These consistent patterns, along with the similar paths that the drifters followed over multiple deployments, suggest that the temporally limited Lagrangian surface-drifter trajectories from the survey period (2010 YD 163-166) are likely a good model for initial coral-larvae dispersal patterns of $M$. capitata in Maunalua Bay during the summer months and may be applicable to larvae of other Hawaiian corals.

\section{Summary}

In all, more than 3 million measurements of meteorologic and oceanographic forcing and the resulting water-column properties were made during this study of factors affecting corallarval dispersal in Maunalua Bay in the summer of 2010. Key findings from these measurements and subsequent analyses include:

(1) The currents at the surface ( $0-2 \mathrm{~m})$ measured by the bottom mounted ADCP's and surface drifters and the currents below the surface $(>2 \mathrm{~m})$ measured by the VM-ADCP were often oriented in opposite directions. Surface currents were generally to the west because of prevailing trade-wind forcing. The currents just below the surface down to the seabed were toward the east, resulting in shear and causing material at different depths in the water-column to be transported in different directions.

(2) Water-column properties, including salinity and temperature, were more uniform throughout the bay than those observed during the winter of 2008-2009 (Storlazzi and others, 2010), likely because there is less rainfall and terrestrial runoff and smaller waves during the summer.

(3) Small eddies were observed off the eastern part of Maunalua Bay in the lee of Koko Head. These eddies likely increase the residence time of particles (such as coral larvae) at the surface in the eastern part of the bay. Just to the west of Paikō, the surface currents were strongly to the west, causing shorter residence times in the central and western parts of the bay than in the eastern part of the bay in the lee of Koko Head.

(4) The consistent meteorologic and oceanographic forcing during the coral-spawning season and the resulting consistent flow patterns and water-column properties suggest that the temporally limited Lagrangian surface-drifter trajectories from the survey period (2010 YD 163256) are likely a good model for initial dispersal patterns of $M$. Capitata coral larvae in Maunalua Bay during the summer months and may be applicable to larvae of other Hawaiian corals.

\section{Acknowledgments}

This work was carried out as part of the USGS Coral Reef Project as part of an effort in the United States and its trust territories to better understand the effect of geologic processes on coral reef ecosystems. Robert Richmond and Jonathan Martinez of the University of Hawai' $i$ and the staff at the University of Hawai'i's Kewalo Marine Laboratory helped with project planning and provided significant logistical help and facilities to support our field operations. Alyssa 
Miller, Dede Mamiya, and others at Mālama Maunalua helped with local project coordination and outreach. Steven Anthony and Ron Rickman of the USGS Pacific Islands Water Science Center and Gordon Tribble of the USGS Pacific Islands Ecological Research Center provided field support and scientific insight while also helping with project coordination. Richard Boyd, the manager at Mt. Terrace Condominiums, provided us with access and security that made it possible to deploy a weather station atop the facility. Matt Zimmerman of Island Divers graciously allowed us the use of the D/V Sea Fox and D/V Leila for nighttime scuba-diving operations and drifter deployment and recovery operations. We would also like to thank Amy Draut and Dan Hoover of the USGS, who contributed numerous excellent suggestions and a timely review of our work.

\section{References Cited}

Heyward, A.J., 1986, Sexual reproduction in five species of the coral Montipora, in Jokiel, P.L., Richmond, R.H., and Rogers, R.A., eds., Coral reef population biology: Kaneohe, Oahu, Hawaii, Institute of Marine Biology, Technical Report 37, p. 170-178.

Kolinski, S.P., and Cox, E.F., 2003, An update on modes and timing of gamete and planula release in Hawaiian scleractinian corals with implications for conservation and management: Pacific Science, v. 57, p. 17-27.

Mate, J.L., Wilson, J., Field, S., and Neves, E.G., 1998, Fertilization dynamics and larval development of the scleractinian coral Montipora verrucosa in Hawai' ${ }^{\prime}$, in Cox, E.F., Krupp, D.A., Jokiel, P.L., eds., Reproduction in reef corals: Kaneohe, Oahu, Hawaii, Hawaii Institute of Marine Biology, Technical Report 42, p. 27-39.

Moberly, R.M., and Chamberlain, T., 1964, Hawaiian beach systems: University of Hawaii, Honolulu, Hawaii Institute of Geophysics Report HIG 64-2, p. 177.

Storlazzi, C.D., Brown, E.K., and Field, M.E., 2006, The application of acoustic Doppler current profilers to measure the timing and patterns of coral-larval dispersal: Coral Reefs, v. 25, p. 369-381.

Storlazzi, C.D., Presto, M.K., Logan, J.B., and Field, M.E., 2010, Coastal circulation and sediment dynamics in Maunalua Bay, Oahu, Hawaii-Measurements of waves, currents, temperature, salinity, and turbidity; November 2008-February 2009: USGS Open-File Report 2010-1217, 60 p., available at http://pubs.usgs.gov/of/2010/1217.

\section{Additional Digital Information}

For additional information on the instrument deployments, please see:

http://walrus.wr.usgs.gov/infobank/a/a210oa/html/a-2-10-oa.meta.html

http://walrus.wr.usgs.gov/infobank/a/a310oa/html/a-3-10-oa.meta.html

For an online PDF version of this report, please see:

http://pubs.usgs.gov/of/2012/1040/. For more information on the U.S. Geological Survey Western

Region's Coastal and Marine Geology Team, please see:

http://walrus.wr.usgs.gov/

For more information on the U.S. Geological Survey's Coral Reef Project,

please see:

http://coralreefs.wr.usgs.gov/ 


\section{Direct Contact Information}

General Project Information

Curt D. Storlazzi (USGS Coral Reef Project chief):

cstorlazzi@usgs.gov

Regarding this Report:

Kathy Presto:

kpresto@usgs.gov 


\section{Tables}

Table 1. Experiment personnel.

\begin{tabular}{|l|c|l|}
\hline Person & Affiliation & Responsibilities \\
\hline Curt Storlazzi & USGS & Chief scientist, diver \\
Kathy Presto & USGS & Oceanographer, Instrument specialist \\
Joshua Logan & USGS & Physical scientist, diver \\
Tom Reiss & USGS & Dive safety officer \\
Pete Dal Ferro & USGS & Mechanical technician, diver \\
Jamie Grover & USGS & Mechanical technician, diver \\
Tim Elfers & USGS & Mechanical technician \\
Kurt Rosenberger & USGS & Oceanographer \\
Joe Reich & F/V Alyce C & Vessel captain \\
\hline
\end{tabular}

Table 2. Instrument package sensors and location information.

\begin{tabular}{|l|c|l|}
\hline Site name & $\begin{array}{c}\text { Depth } \\
{[\mathrm{m}]}\end{array}$ & Sensors \\
\hline Wailupe 20 m & 22 & Nortek 600 kHz AWAC acoustic Doppler current profiler \\
22 & Seabird SBE-37SI Microcat conductivity-temperature sensor \\
\hline Diamond Head 20 m & 16 & $\begin{array}{l}\text { RD Instruments 600 kHz Workhorse Monitor acoustic Doppler current } \\
\text { profiler }\end{array}$ \\
\hline Paikō 30 m & 30 & Seabird SBE-37SI Microcat conductivity-temperature sensor \\
\hline Paikō 20 m & 20 & Seabird SBE-37SI Microcat conductivity-temperature sensor \\
\hline Paikō $10 \mathrm{~m}$ & 20 & profiler \\
& 9 & $\begin{array}{l}\text { Seabird SBE-37SI Microcat conductivity-temperature sensor } \\
\text { profiler }\end{array}$ \\
\hline Paikō 5 m & 9 & Seabird SBE-37SI Microcat conductivity-temperature sensor \\
\hline Weather Station & 5 & Seabird SBE-37SI Microcat conductivity-temperature sensor \\
\hline
\end{tabular}

${ }^{1}$ Height, in meters

Table 3. Instrument package location information.

\begin{tabular}{|l|c|c|}
\hline Site name & $\begin{array}{c}\text { Latitude } \\
\text { [decimal degrees] }\end{array}$ & $\begin{array}{c}\text { Longitude } \\
\text { [decimal degrees] }\end{array}$ \\
\hline Wailupe 20 m & 21.2582760 & -157.7543004 \\
Diamond Head 20 m & 21.2449005 & -157.7990587 \\
Paikō 30 m & 21.2561031 & -157.7190399 \\
Paikō 20 m & 21.2603369 & -157.7201058 \\
Paikō 10 m & 21.2720695 & -157.7245325 \\
Paikō 5 m & 21.2739577 & -157.7243602 \\
Weather Station (WS) & 21.2876970 & -157.7194594 \\
\hline
\end{tabular}


Table 4. Water-column profiler (WCP) cast location and depth information.

\begin{tabular}{|c|c|c|c|}
\hline Cast location & $\begin{array}{c}\text { Latitude } \\
\text { [decimal degrees] }\end{array}$ & $\begin{array}{c}\text { Longitude } \\
\text { [decimal degrees] }\end{array}$ & $\begin{array}{l}\text { Depth } \\
\text { [m] }\end{array}$ \\
\hline 1 & 21.25573 & -157.711634 & 36.9 \\
\hline 2 & 21.27250 & -157.719923 & 6.4 \\
\hline 3 & 21.27292 & -157.736445 & 7.1 \\
\hline 4 & 21.26427 & -157.733499 & 18.1 \\
\hline 5 & 21.27055 & -157.715829 & 4.4 \\
\hline 6 & 21.28028 & -157.712304 & 1.9 \\
\hline 7 & 21.26060 & -157.712136 & 5.4 \\
\hline 8 & 21.25768 & -157.731398 & 20.6 \\
\hline 9 & 21.27289 & -157.736287 & 7.1 \\
\hline 10 & 21.26912 & -157.756957 & 5.9 \\
\hline 11 & 21.25406 & -157.752922 & 19.9 \\
\hline 12 & 21.25028 & -157.769402 & 24.6 \\
\hline 13 & 21.26302 & -157.774762 & 10.9 \\
\hline 14 & 21.25175 & -157.799892 & 7.6 \\
\hline 15 & 21.24315 & -157.750340 & 22.1 \\
\hline 16 & 21.24412 & -157.797837 & 15.4 \\
\hline 17 & 21.25191 & -157.799873 & 6.1 \\
\hline 18 & 21.26388 & -157.774500 & 5.9 \\
\hline 19 & 21.25023 & -157.769893 & 23.1 \\
\hline 20 & 21.25361 & -157.752997 & 20.4 \\
\hline 21 & 21.26914 & -157.756860 & 5.4 \\
\hline 22 & 21.27347 & -157.735662 & 3.9 \\
\hline 23 & 21.25733 & -157.731310 & 21.1 \\
\hline 24 & 21.26056 & -157.712052 & 5.1 \\
\hline 25 & 21.28019 & -157.712175 & 2.4 \\
\hline 26 & 21.27056 & -157.715975 & 5.4 \\
\hline 27 & 21.26383 & -157.733745 & 18.9 \\
\hline 28 & 21.27294 & -157.721457 & 5.4 \\
\hline 29 & 21.25687 & -157.712139 & 32.1 \\
\hline 30 & 21.25602 & -157.711589 & 37.6 \\
\hline 31 & 21.27168 & -157.719714 & 5.4 \\
\hline 32 & 21.27342 & -157.736055 & 4.9 \\
\hline 33 & 21.26406 & -157.733364 & 18.1 \\
\hline 34 & 21.27041 & -157.716249 & 5.4 \\
\hline 35 & 21.28051 & -157.712169 & 1.1 \\
\hline 36 & 21.26038 & -157.712024 & 5.6 \\
\hline 37 & 21.25761 & -157.730646 & 20.9 \\
\hline 38 & 21.26931 & -157.756982 & 4.9 \\
\hline 39 & 21.25397 & -157.752879 & 19.9 \\
\hline 40 & 21.25024 & -157.769337 & 24.9 \\
\hline 41 & 21.26360 & -157.774937 & 6.4 \\
\hline 42 & 21.25210 & -157.799914 & 7.4 \\
\hline 43 & 21.24414 & -157.798911 & 20.4 \\
\hline 44 & 21.24423 & -157.799100 & 19.9 \\
\hline 45 & 21.25233 & -157.800075 & 4.1 \\
\hline 46 & 21.26398 & -157.774537 & 5.9 \\
\hline 47 & 21.24998 & -157.769916 & 20.4 \\
\hline 48 & 21.25389 & -157.752797 & 20.1 \\
\hline 49 & 21.26886 & -157.756978 & 5.9 \\
\hline 50 & 21.27362 & -157.735817 & 6.1 \\
\hline 51 & 21.25756 & -157.731307 & 20.9 \\
\hline 52 & 21.26013 & -157.712311 & 12.1 \\
\hline
\end{tabular}


Table 4. Water-column profiler (WCP) cast location and depth information.-Continued

\begin{tabular}{|l|c|c|c|}
\hline Cast location & $\begin{array}{c}\text { Latitude } \\
\text { [decimal degrees] }\end{array}$ & $\begin{array}{c}\text { Longitude } \\
\text { [decimal degrees] }\end{array}$ & $\begin{array}{c}\text { Depth } \\
\text { [m] }\end{array}$ \\
\hline 53 & 21.28065 & -157.712155 & 1.4 \\
54 & 21.27056 & -157.715854 & 4.4 \\
55 & 21.26409 & -157.733478 & 18.4 \\
56 & 21.27317 & -157.721260 & 5.4 \\
57 & 21.25603 & -157.711875 & 37.1 \\
\hline
\end{tabular}

Table 5. Vessel-mounted acoustic Doppler current profiler (VM-ADCP) log information. [HST, Hawaii Standard Time]

\begin{tabular}{|c|c|c|c|c|c|}
\hline Line number & Line name & Filename & Date [MM/DD/YYYY] & Start time [HST] & Stop time [HST] \\
\hline 1 & T-5 & ADCP_001 & $06 / 12 / 2010$ & 09:23:05 & 09:41:20 \\
\hline 3 & T-6 & ADCP_003 & $06 / 12 / 2010$ & $10: 12: 05$ & $10: 25: 40$ \\
\hline 4 & T-7 & ADCP_004 & $06 / 12 / 2010$ & $10: 37: 30$ & $10: 53: 20$ \\
\hline 5 & T-8 & ADCP_005 & $06 / 12 / 2010$ & 10:58:09 & 11:03:37 \\
\hline 6 & $\mathrm{~T}-9$ & ADCP_006 & 06/12/2010 & $11: 20: 02$ & $11: 34: 22$ \\
\hline 7 & T-10 & ADCP_007 & $06 / 12 / 2010$ & $11: 37: 22$ & $11: 51: 21$ \\
\hline 8 & $\mathrm{~T}-11$ & ADCP_008 & $06 / 12 / 2010$ & $11: 55: 56$ & 12:09:56 \\
\hline 9 & $\mathrm{~T}-12$ & ADCP_009 & $06 / 12 / 2010$ & $12: 12: 17$ & $12: 25: 46$ \\
\hline 10 & $\mathrm{~T}-13$ & ADCP_010 & $06 / 12 / 2010$ & $12: 40: 51$ & $12: 52: 31$ \\
\hline 11 & T-14 & ADCP_011 & $06 / 12 / 2010$ & $12: 57: 00$ & $13: 15: 46$ \\
\hline 12 & T-15 & ADCP_012 & $06 / 12 / 2010$ & 13:18:04 & $13: 26: 34$ \\
\hline 13 & T-15 & ADCP_013 & $06 / 13 / 2010$ & 08:38:05 & $08: 46: 03$ \\
\hline 14 & $\mathrm{~T}-14$ & ADCP_014 & 06/13/2010 & $08: 48: 54$ & $09: 12: 54$ \\
\hline 15 & $\mathrm{~T}-13$ & ADCP_015 & 06/13/2010 & 09:14:55 & $09: 27: 45$ \\
\hline 16 & $\mathrm{~T}-12$ & ADCP_016 & $06 / 13 / 2010$ & $09: 44: 23$ & 09:59:11 \\
\hline 17 & $\mathrm{~T}-11$ & ADCP_017 & $06 / 13 / 2010$ & 10:01:42 & $10: 21: 30$ \\
\hline 18 & $\mathrm{~T}-10$ & ADCP_018 & $06 / 13 / 2010$ & 10:23:01 & 10:38:51 \\
\hline 19 & T-9 & ADCP_019 & $06 / 13 / 2010$ & 10:43:04 & $10: 59: 35$ \\
\hline 20 & T-8 & ADCP_020 & $06 / 13 / 2010$ & $11: 19: 45$ & $11: 27: 04$ \\
\hline 21 & T-7 & ADCP_021 & $06 / 13 / 2010$ & $11: 29: 26$ & $11: 42: 55$ \\
\hline 22 & T-6 & ADCP 022 & $06 / 13 / 2010$ & $11: 54: 42$ & $12: 07: 19$ \\
\hline 23 & T-5 & ADCP_023 & $06 / 13 / 2010$ & $12: 10: 41$ & $12: 24: 52$ \\
\hline 24 & T-4 & ADCP_024 & $06 / 13 / 2010$ & $12: 28: 29$ & $12: 31: 57$ \\
\hline 25 & T-3 & ADCP_025 & $06 / 14 / 2010$ & 09:21:48 & $09: 23: 30$ \\
\hline 26 & T-4 & ADCP_026 & $06 / 14 / 2010$ & 09:26:08 & $09: 29: 02$ \\
\hline 27 & T-5 & ADCP_027 & $06 / 14 / 2010$ & 09:33:49 & 09:50:17 \\
\hline 28 & T-6 & ADCP_028 & $06 / 14 / 2010$ & $09: 52: 52$ & - \\
\hline 29 & T-6 & ADCP_029 & $06 / 14 / 2010$ & $09: 54: 28$ & $10: 06: 46$ \\
\hline 30 & T-7 & ADCP_030 & $06 / 14 / 2010$ & $10: 17: 43$ & $10: 34: 32$ \\
\hline 31 & T-8 & ADCP_031 & $06 / 14 / 2010$ & $10: 37: 14$ & $10: 47: 14$ \\
\hline 32 & $\mathrm{~T}-9$ & ADCP_032 & $06 / 14 / 2010$ & 11:05:29 & $11: 21: 00$ \\
\hline 33 & T-10 & ADCP_033 & $06 / 14 / 2010$ & $11: 24: 29$ & 11:41:02 \\
\hline 34 & T-11 & ADCP_034 & $06 / 14 / 2010$ & $11: 42: 55$ & $11: 59: 14$ \\
\hline 35 & T-12 & ADCP_035 & $06 / 14 / 2010$ & $12: 02: 04$ & $12: 17: 15$ \\
\hline 36 & $\mathrm{~T}-13$ & ADCP_036 & $06 / 14 / 2010$ & $12: 35: 10$ & $12: 48: 52$ \\
\hline 37 & T-14a & ADCP_037 & $06 / 14 / 2010$ & 12:53:09 & $13: 09: 52$ \\
\hline 38 & $T-14 b$ & ADCP_038 & $06 / 14 / 2010$ & $13: 10: 49$ & $13: 17: 27$ \\
\hline 39 & T-15 & ADCP_039 & $06 / 14 / 2010$ & $13: 19: 45$ & $13: 26: 52$ \\
\hline 40 & T-15 & ADCP-040 & $06 / 15 / 2010$ & 08:59:09 & $09: 07: 39$ \\
\hline 41 & T-14 & ADCP_041 & $06 / 15 / 2010$ & $09: 10: 27$ & 09:34:48 \\
\hline 42 & $\mathrm{~T}-13$ & ADCP_042 & $06 / 15 / 2010$ & 09:37:18 & 09:50:48 \\
\hline 43 & T-12 & ADCP_043 & $06 / 15 / 2010$ & 10:08:39 & $10: 23: 41$ \\
\hline 44 & $\mathrm{~T}-11$ & ADCP_044 & $06 / 15 / 2010$ & 10:39:13 & $10: 57: 53$ \\
\hline 45 & $\mathrm{~T}-10$ & ADCP_045 & $06 / 15 / 2010$ & 11:02:02 & 11:16:41 \\
\hline 46 & T-9 & ADCP_046 & $06 / 15 / 2010$ & $11: 20: 39$ & $11: 36: 28$ \\
\hline
\end{tabular}


Table 5. Vessel-mounted acoustic Doppler current profiler (VM-ADCP) log information.-Continued

\begin{tabular}{|l|c|c|c|c|c|}
\hline Line number & Line name & Filename & Date [MM/DD/YYYY] & Start time [HST] & Stop time [HST] \\
\hline 47 & T-8 & ADCP_047 & $06 / 15 / 2010$ & $11: 54: 32$ & $12: 03: 22$ \\
48 & T-7 & ADCP_048 & $06 / 15 / 2010$ & $12: 05: 53$ & $12: 22: 04$ \\
49 & T-6 & ADCP_049 & $06 / 15 / 2010$ & $12: 33: 04$ & $12: 46: 02$ \\
50 & T-5 & ADCP_050 & $06 / 15 / 2010$ & $12: 49: 18$ & $13: 05: 09$ \\
51 & T-4 & ADCP_051 & $06 / 15 / 2010$ & $13: 10: 13$ & $13: 13: 20$ \\
\hline
\end{tabular}

Table 6. Lagrangian surface-drifter log information.

[HST, Hawaii Standard Time]

\begin{tabular}{|l|c|c|c|c|c|c|}
\hline $\begin{array}{l}\text { Start } \\
\text { Location } \\
\text { ID }\end{array}$ & $\begin{array}{c}\text { Start Latitude } \\
\text { [decimal } \\
\text { degrees] }\end{array}$ & $\begin{array}{c}\text { Start Longitude } \\
\text { [decimal } \\
\text { degrees] }\end{array}$ & $\begin{array}{c}\text { Start Date and } \\
\text { Time [HST] }\end{array}$ & $\begin{array}{c}\text { Stop Latitude } \\
\text { [decimal } \\
\text { degrees] }\end{array}$ & $\begin{array}{c}\text { Stop Longitude } \\
\text { [decimal } \\
\text { degrees] }\end{array}$ & $\begin{array}{c}\text { Stop Date } \\
\text { and Time } \\
\text { [HST] }\end{array}$ \\
\hline A & 21.27194 & -157.72471 & $6 / 12 / 2010$ & 21.24962 & -157.80060 & $6 / 13 / 2010$ \\
& & & $22: 50$ & & & $13: 18$ \\
C & 21.26963 & -157.74484 & $6 / 12 / 2010$ & 21.26643 & -157.87117 & $6 / 13 / 2010$ \\
& & & $23: 27$ & & & \\
A & 21.27221 & -157.72432 & $6 / 13 / 2010$ & 21.25023 & -157.80171 & $6 / 14 / 2010$ \\
& & & $23: 18$ & & & $13: 40$ \\
D & 21.25647 & -157.70618 & $6 / 13 / 2010$ & 21.26444 & -157.72078 & $6 / 14 / 2010$ \\
& & & $23: 33$ & & & $19: 57$ \\
A & 21.27210 & -157.72404 & $6 / 14 / 2010$ & 21.26935 & -157.76783 & $6 / 15 / 2010$ \\
& & & $23: 11$ & & & \\
B & 21.26389 & -157.71682 & $6 / 14 / 2010$ & 21.25280 & -157.85039 & $6 / 15 / 2010$ \\
& & & $23: 18$ & & & \\
\hline
\end{tabular}

Table 7. Meteorological statistics.

[All statistics were calculated from 2010 Year Days 163-256; wind direction is "from"]

\begin{tabular}{|l|c|c|c|}
\hline Parameter & $\begin{array}{c}\text { Mean } \pm \text { 1 standard } \\
\text { deviation }\end{array}$ & Minimum & Maximum \\
\hline Barometric pressure [mb] & $1009.38 \pm 1.27$ & 1005.75 & 1013.25 \\
Air temperature [ $\left.{ }^{\circ} \mathrm{C}\right]$ & $24.99 \pm 1.30$ & 21.19 & 29.19 \\
Precipitation [mm] & $0.014 \pm 0.10$ & 0 & 2.5 \\
Wind speed [m/s] & $6.28 \pm 1.52$ & 1.62 & 11.81 \\
Wind direction [ $\left.{ }^{\circ}\right]$ & $78.69 \pm 10.13$ & 0.31 & 135.88 \\
\hline
\end{tabular}

Table 8. Wave statistics.

[All statistics were calculated from 2010Year Days 163-256; wave direction is "from"]

\begin{tabular}{|c|c|c|c|c|}
\hline Site name & Parameter & $\begin{array}{c}\text { Mean } \pm 1 \text { standard } \\
\text { deviation }\end{array}$ & Minimum & Maximum \\
\hline \multirow[t]{3}{*}{ Wailupe $20 \mathrm{~m}^{1}$} & Height [m] & $0.68 \pm 0.16$ & 0.59 & 1.48 \\
\hline & Period [s] & $4.33 \pm 0.47$ & 3.04 & 5.81 \\
\hline & Direction $\left[^{\circ}\right]$ & $152.06 \pm 8.50$ & 127.33 & 175.18 \\
\hline \multirow[t]{3}{*}{ Diamond Head 20 m } & Height $[\mathrm{m}]$ & $0.85 \pm 0.21$ & 0.43 & 1.91 \\
\hline & Period [s] & $8.14 \pm 1.4$ & 5.4 & 14.1 \\
\hline & Direction $\left[^{\circ}\right]$ & $179.11 \pm 23.59$ & 87.0 & 223.0 \\
\hline \multirow[t]{3}{*}{ Paikō 20 m } & Height [m] & N.D. $\pm N . D$. & N.D. & N.D. \\
\hline & Period [s] & N.D. $\pm N . D$. & N.D. & N.D. \\
\hline & Direction $\left[{ }^{0}\right]$ & N.D. $\pm N . D$. & N.D. & N.D \\
\hline \multirow[t]{3}{*}{ Paikō 10 m } & Height [m] & $0.71 \pm 0.32$ & 0.17 & 1.49 \\
\hline & Period [s] & $8.30 \pm 1.56$ & 4.7 & 13.9 \\
\hline & Direction $\left[{ }^{\circ}\right]$ & $191.88 \pm 8.25$ & 159.0 & 222.0 \\
\hline
\end{tabular}

${ }^{1}$ Statistics were calculated only for 2010 Year Days 223-256.

N.D., No data. 
Table 9. Current statistics.

[All statistics were calculated from 2010 Year Days 163-256; current direction is "going to"]

\begin{tabular}{|c|c|c|c|c|c|}
\hline Site name & Parameter & Depth [m] & Mean \pm 1 standard deviation & Minimum & Maximum \\
\hline \multirow[t]{4}{*}{ Wailupe $20 \mathrm{~m}$} & Speed $[\mathrm{m} / \mathrm{s}]$ & 2 [N.S.] & $0.08 \pm 0.15$ & 0.00 & 0.96 \\
\hline & Direction $\left[{ }^{\circ}\right]$ & 2 [N.S.] & $180.92 \pm 91.21$ & 0.0 & 359.95 \\
\hline & Speed [m/s] & 19 [N.B.] & $0.04 \pm 0.15$ & 0.00 & 0.86 \\
\hline & Direction $\left[^{\circ}\right]$ & 19 [N.B.] & $241.19 \pm 97.69$ & 0.0 & 359.82 \\
\hline \multirow[t]{4}{*}{ Diamond Head $20 \mathrm{~m}$} & Speed $[\mathrm{m} / \mathrm{s}]$ & 2 [N.S.] & $0.08 \pm 0.24$ & 0.01 & 1.00 \\
\hline & Direction $\left[^{\circ}\right]$ & 2 [N.S.] & $180.92 \pm 84.33$ & 6.14 & 332.22 \\
\hline & Speed $[\mathrm{m} / \mathrm{s}]$ & 15 [N.B.] & $0.05 \pm 0.14$ & 0.00 & 0.87 \\
\hline & Direction $\left[^{\circ}\right]$ & 15 [N.B.] & $215.69 \pm 80.44$ & 8.48 & 336.96 \\
\hline \multirow[t]{4}{*}{ Paikō 20 m } & Speed $[\mathrm{m} / \mathrm{s}]$ & 2 [N.S.] & N.D. $\pm N . D$. & N.D. & N.D. \\
\hline & Direction $\left[^{0}\right]$ & 2 [N.S.] & N.D. $\pm N . D$. & N.D. & N.D. \\
\hline & Speed $[\mathrm{m} / \mathrm{s}]$ & 19 [N.B.] & N.D. $\pm N . D$. & N.D. & N.D. \\
\hline & Direction [0] & 19 [N.B.] & N.D. $\pm N . D$. & N.D. & N.D. \\
\hline \multirow[t]{4}{*}{ Paikō 10 m } & Speed [m/s] & 2 [N.S.] & $0.04 \pm 0.06$ & 0.00 & 0.40 \\
\hline & Direction $\left[^{\circ}\right]$ & 2 [N.S.] & $123.83 \pm 84.33$ & 1.34 & 358.58 \\
\hline & Speed $[\mathrm{m} / \mathrm{s}]$ & 9 [N.B.] & $0.03 \pm 0.03$ & 0.00 & 0.19 \\
\hline & Direction $\left[{ }^{\circ}\right]$ & 9 [N.B.] & $81.62 \pm 89.46$ & 2.39 & 358.68 \\
\hline
\end{tabular}

N.D., No data.

N.S., Near surface.

N.B., Near bed.

Table 10. Water temperature statistics.

[All statistics were calculated for 2010 Year Days 163-256]

\begin{tabular}{|l|c|c|c|c|}
\hline Site name & $\begin{array}{c}\text { Depth } \\
{[\mathrm{m}]}\end{array}$ & $\begin{array}{c}\text { Mean } \pm \text { standard } \\
\text { deviation } \\
{\left[{ }^{\circ} \mathrm{C}\right]}\end{array}$ & $\begin{array}{c}\text { Minimum } \\
{\left[{ }^{\circ} \mathrm{C}\right]}\end{array}$ & $\begin{array}{c}\text { Maximum } \\
{\left[{ }^{\circ} \mathrm{C}\right]}\end{array}$ \\
\hline Wailupe $20 \mathrm{~m}$ & 22 & $25.60 \pm 0.22$ & 24.92 & 26.31 \\
Diamond Head 20 m & 16 & $25.60 \pm 0.22$ & 24.40 & 26.33 \\
Paikō 30 m & 30 & $25.42 \pm 0.41$ & 22.96 & 26.22 \\
Paikō $20 \mathrm{~m}^{1}$ & 20 & $25.46 \pm 0.28$ & 24.47 & 26.30 \\
Paikō $10 \mathrm{~m}$ & 9 & $25.58 \pm 0.24$ & 24.85 & 26.33 \\
Paikō 5 m & 5 & $25.65 \pm 0.29$ & 24.73 & 26.79 \\
\hline
\end{tabular}

${ }^{1}$ Statistics were calculated only for 2010 Year Days 162-222.

Table 11. Salinity statistics.

[All statistics were calculated for 2010 Year Days 163-256; PSU, Practical Salinity Units]

\begin{tabular}{|l|c|c|c|c|}
\hline Site Name & $\begin{array}{c}\text { Depth } \\
{[\mathrm{m}]}\end{array}$ & $\begin{array}{c}\text { Mean } \pm \text { 1 standard } \\
\text { deviation } \\
\text { [PSU] }\end{array}$ & $\begin{array}{c}\text { Minimum } \\
\text { [PSU] }\end{array}$ & $\begin{array}{c}\text { Maximum } \\
\text { [PSU] }\end{array}$ \\
\hline Wailupe 20 m & 22 & $35.01 \pm 0.12$ & 33.94 & 35.25 \\
Diamond Head 20 m & 16 & $34.64 \pm 1.21$ & 28.87 & 35.25 \\
Paikō 30 m & 30 & $35.09 \pm 0.06$ & 34.28 & 35.82 \\
Paikō 20 m & 20 & $34.78 \pm 0.19$ & 33.44 & 35.10 \\
Paikō 10 m & 9 & $34.74 \pm 0.66$ & 28.22 & 35.45 \\
Paikō 5 m & 5 & $35.09 \pm 0.08$ & 33.08 & 35.47 \\
\hline
\end{tabular}

${ }^{1}$ Statistics were calculated only for 2010 Year Days 162-222. 
Table 12. Lagrangian surface-drifter statistics.

\begin{tabular}{|l|c|c|c|c|c|}
\hline Start location ID & Duration $[\mathrm{hr}]$ & $\begin{array}{c}\text { Total distance } \\
\text { Traveled }[\mathrm{km}]\end{array}$ & $\begin{array}{c}\text { Net distance } \\
\text { Traveled }[\mathrm{km}]\end{array}$ & Net direction $\left[^{0}\right]$ & $\begin{array}{c}\text { Max velocity } \\
{[\mathrm{m} / \mathrm{s}]}\end{array}$ \\
\hline A & $14: 20$ & 15.8 & 8.2 & 252 & 0.57 \\
C & $8: 20$ & 14.2 & 13.1 & 268 & 0.75 \\
A & $14: 15$ & 13.3 & 8.4 & 253 & 0.53 \\
D & $20: 20$ & 15.8 & 1.7 & 300 & 0.64 \\
A & $11: 00$ & 6.4 & 4.5 & 266 & 0.46 \\
B & $09: 05$ & 16.0 & 13.9 & 265 & 1.09 \\
\hline
\end{tabular}




\section{Figures}
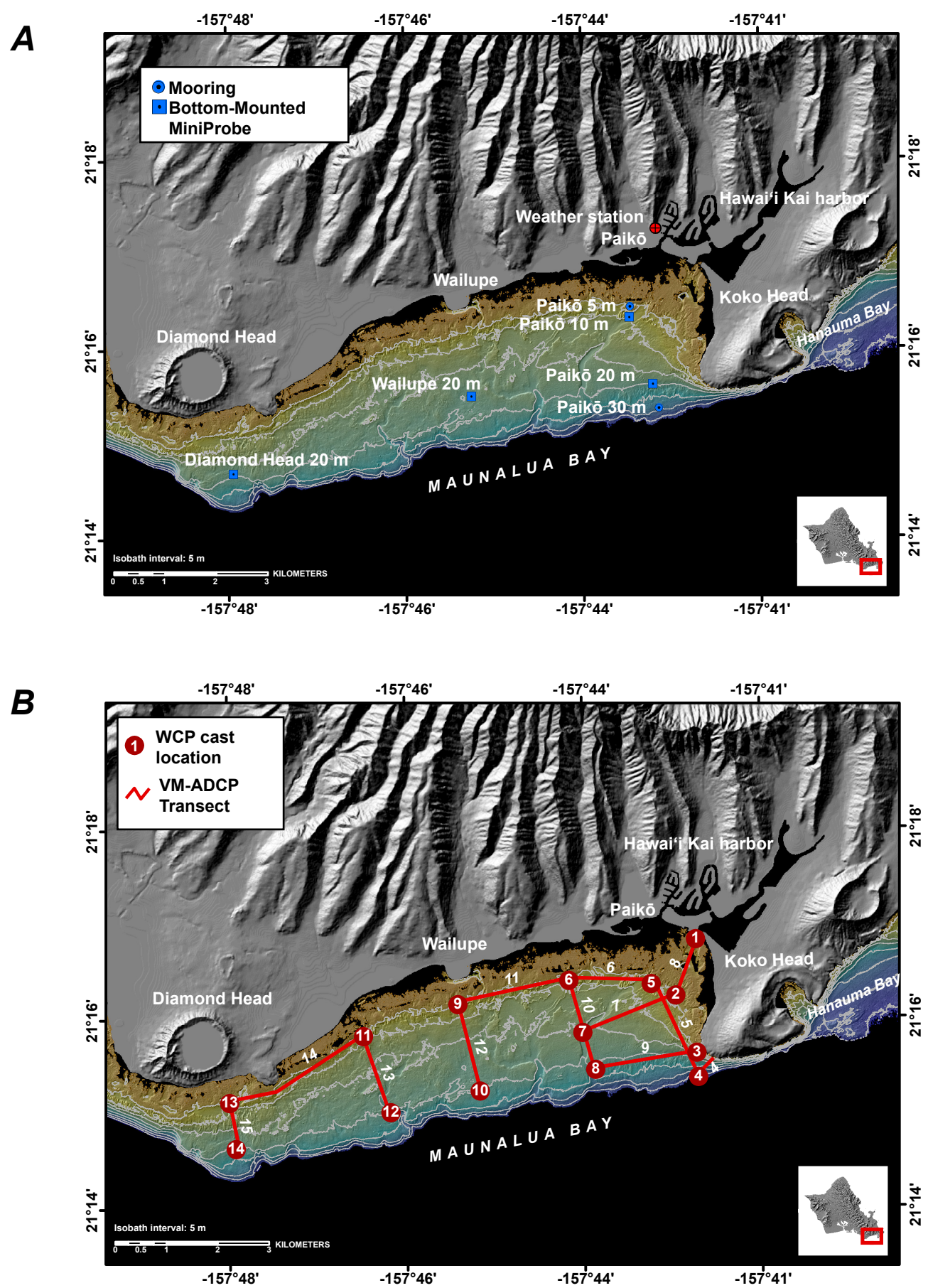

Figure 1. A, Aerial photograph and scanning hydrographic operational airborne lidar surveys (SHOALS) bathymetric map of Maunalua Bay and its location on O'ahu, Hawaii. Also shown are the location of instrument packages and major landmarks. B, Vessel-mounted acoustic Doppler current-profiler (VMADCP) tracklines and water-column Profiler (WCP) cast locations are denoted by italic white numbers and numbers in dots, respectively. 


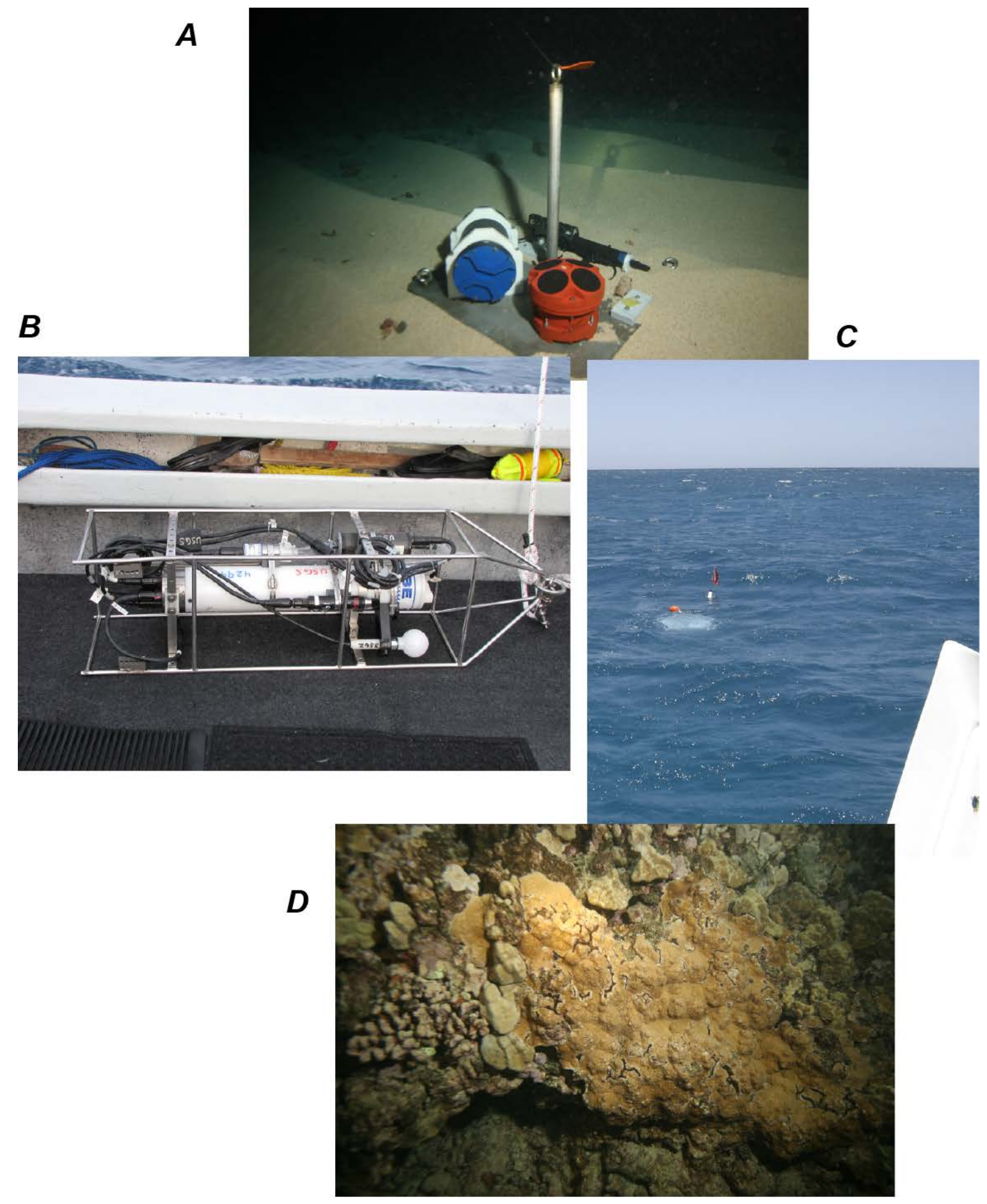

Figure 2. A-C, Photographs of the equipment used in Maunalua Bay during the 2010 summer experiment. $A$, Underwater photograph of a MiniProbe with an acoustic Doppler current profiler (ADCP) and a conductivity and temperature (CT) sensor along the $10-\mathrm{m}$ isobath at the Paiko 10-m site. $B$, Water-column Profiler (WCP). C, Example of a Lagrangian surface drifter in the ocean taken from the R/V Alyce C. D, Example of the coral, Montipora capitata, the spawning of which was the focus of the 2010 summer experiment. 


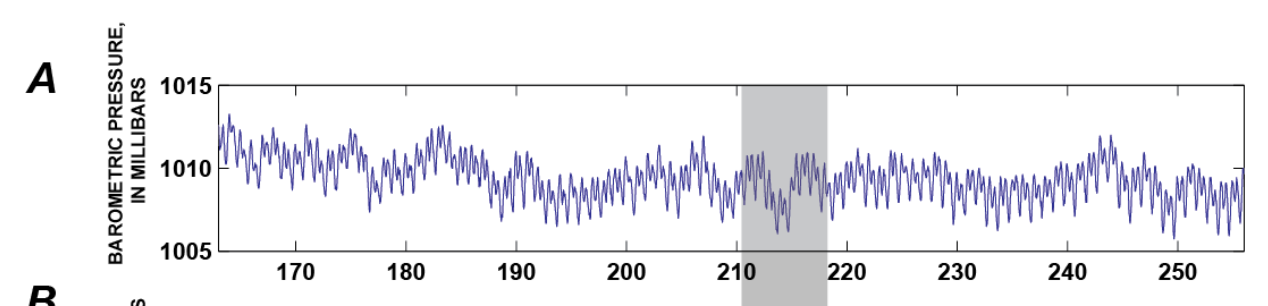

$\boldsymbol{B}$
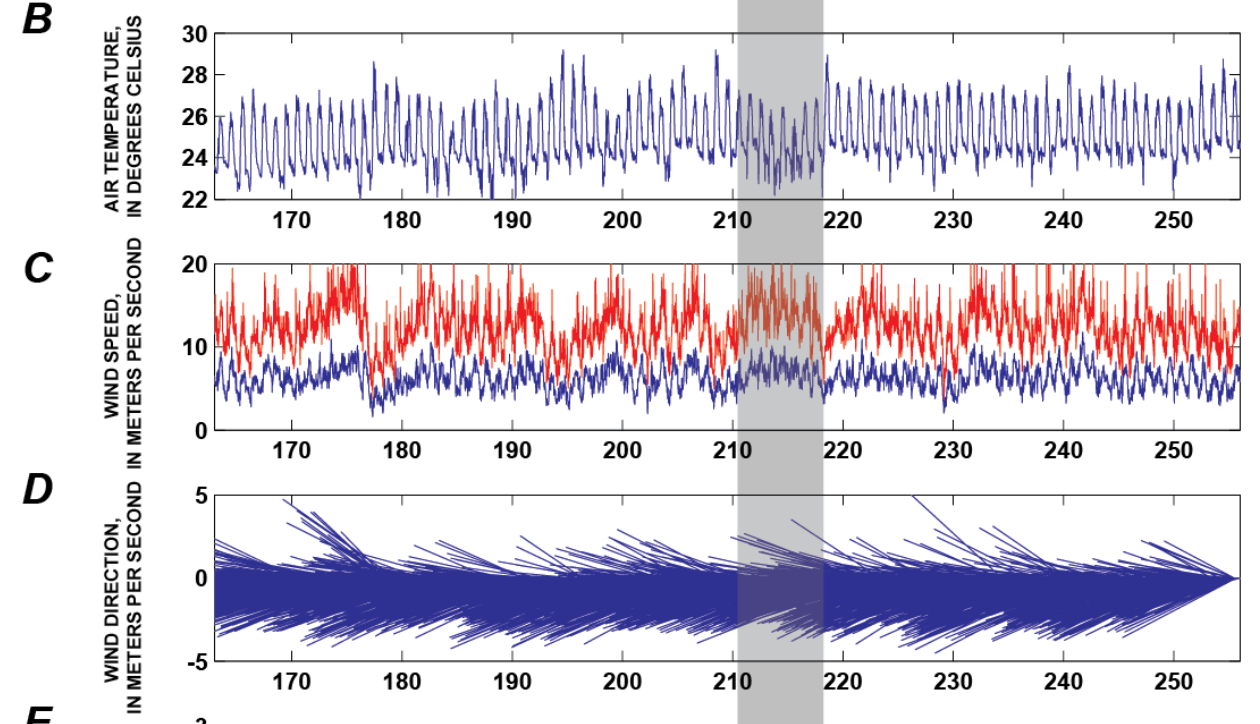

E
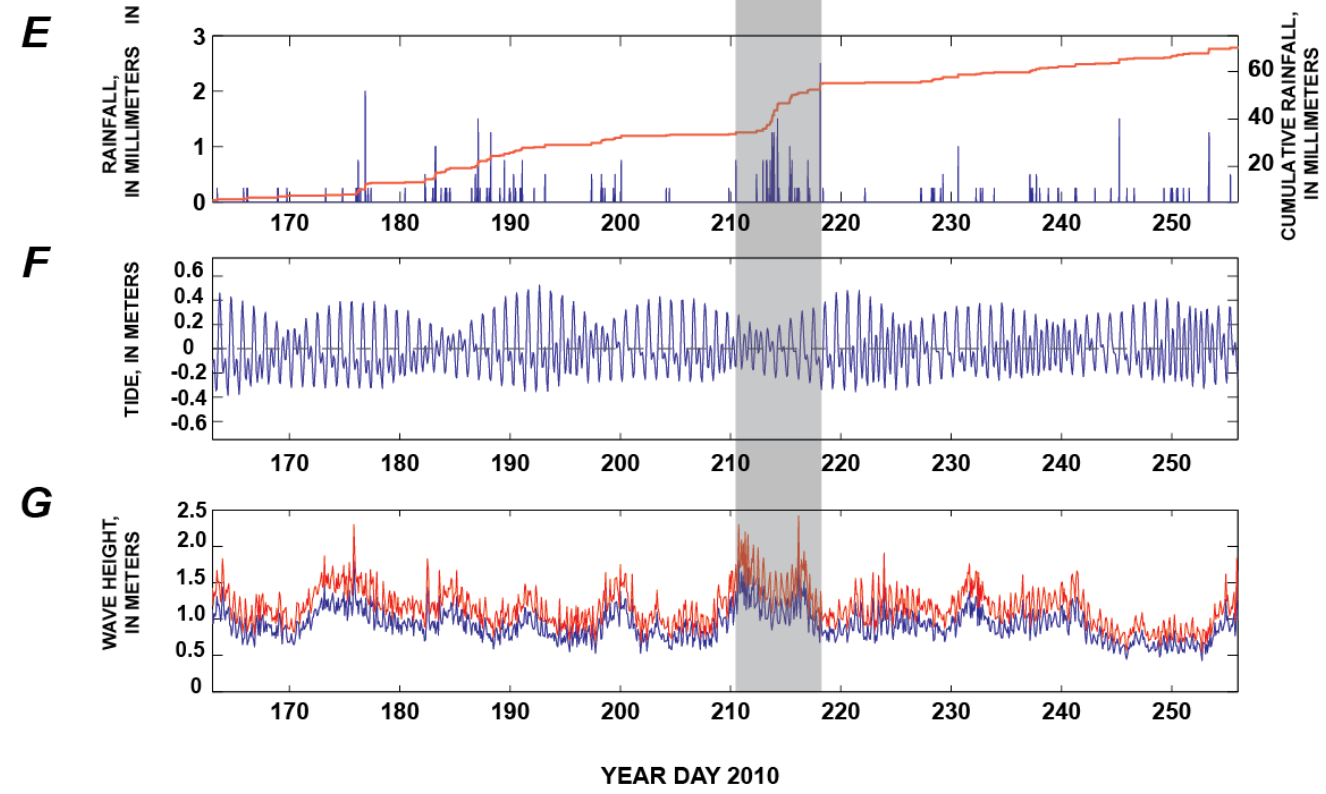

Figure 3. Time-series plot of meteorologic and oceanographic forcing in Maunalua Bay during the 2010 summer experiment. $A$, Barometric pressure, in millibars. $B$, Air temperature, in degrees Celsius. $C$, Wind speed, in meters per seconds, with average wind speed in blue and peak wind speed in red. $D$, Wind speed and direction, in meters per second from true north. E, Half-hour rainfall (blue) and cumulative rainfall (red), in millimeters. $F$, Tidal height, in meters. $G$, Average (blue) and peak (red) wave height, in meters. The shaded area highlights the largest wave event during the summer and the associated meteorological conditions. The tidal signal reflects the semidiurnal nature of the tide and the time period shown encompassed 6 spring-neap tidal cycles. 


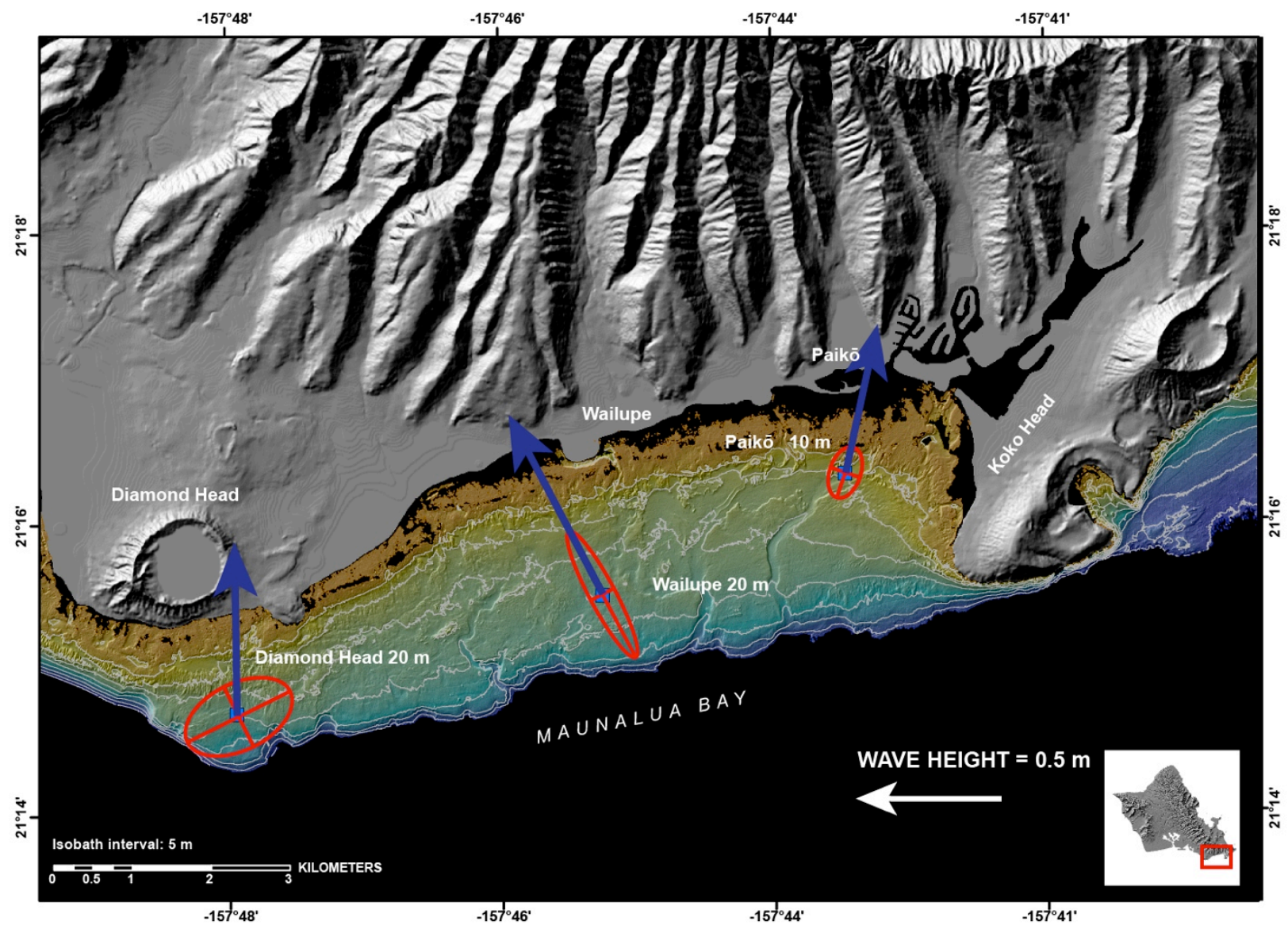

Figure 4. Map showing the mean (blue vectors) and variability (red ellipses) in wave heights and directions, in meters from true north, in Maunalua Bay during the 2010 summer experiment for the Diamond Head 20-m, Wailupe 20-m, and Paikō 10-m sites. All of the sites show the predominant wave direction from the south, with the largest waves measured in the more exposed central part of the bay. 


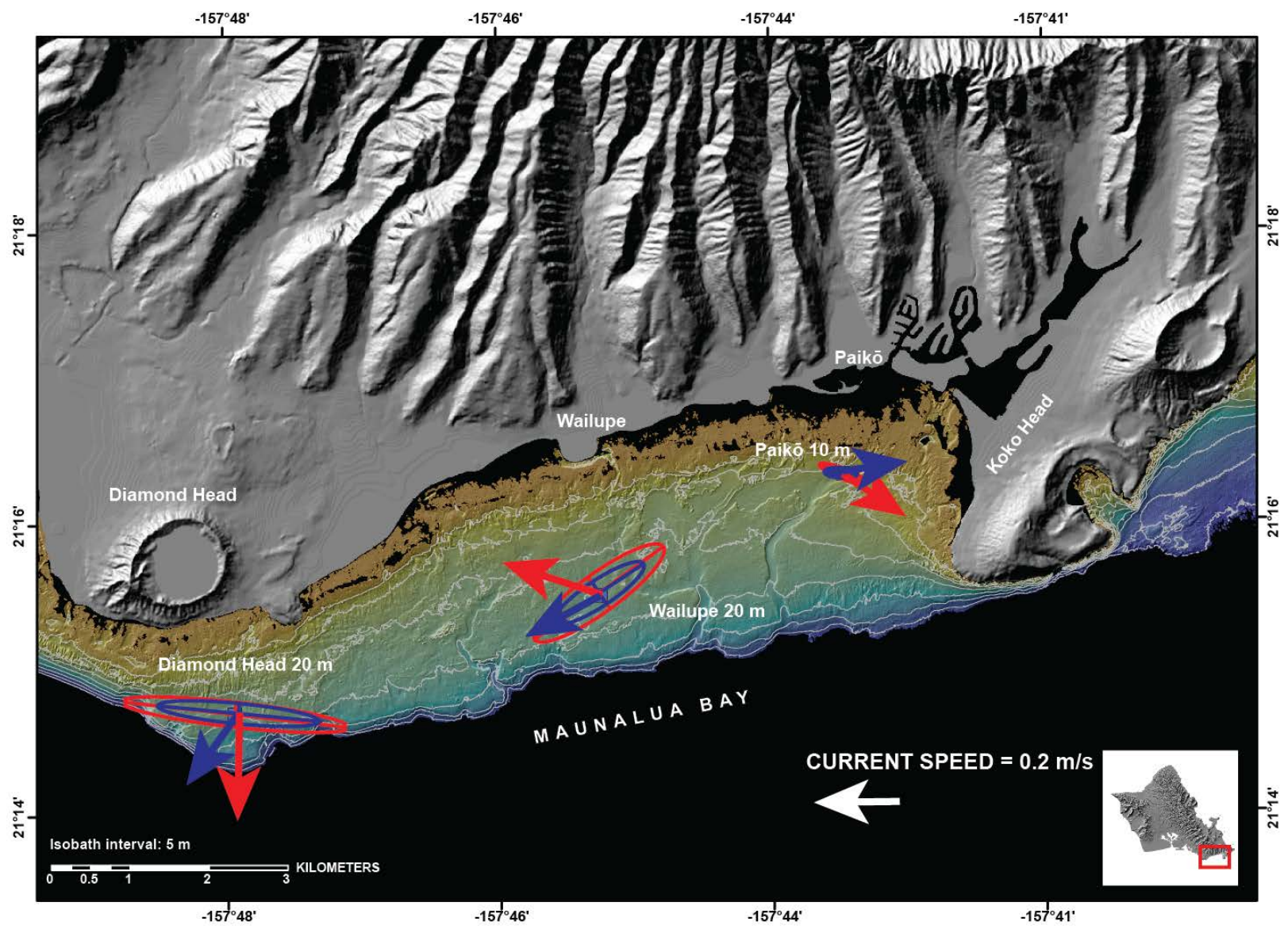

Figure 5. Map showing the mean (vectors) and variability (ellipses) in current speeds and directions, in meters per second from true north, in Maunalua Bay for the 2010 summer experiment. Red, nearsurface currents; blue, near-bed currents. Currents directions in the bay vary as a result of proximity to headlands and local bathymetry. Current speeds are greater near the surface than near the bed and are mainly to the west and offshore except at the Paikō 10-m site, which was deployed in the lee of Koko Head crater. 


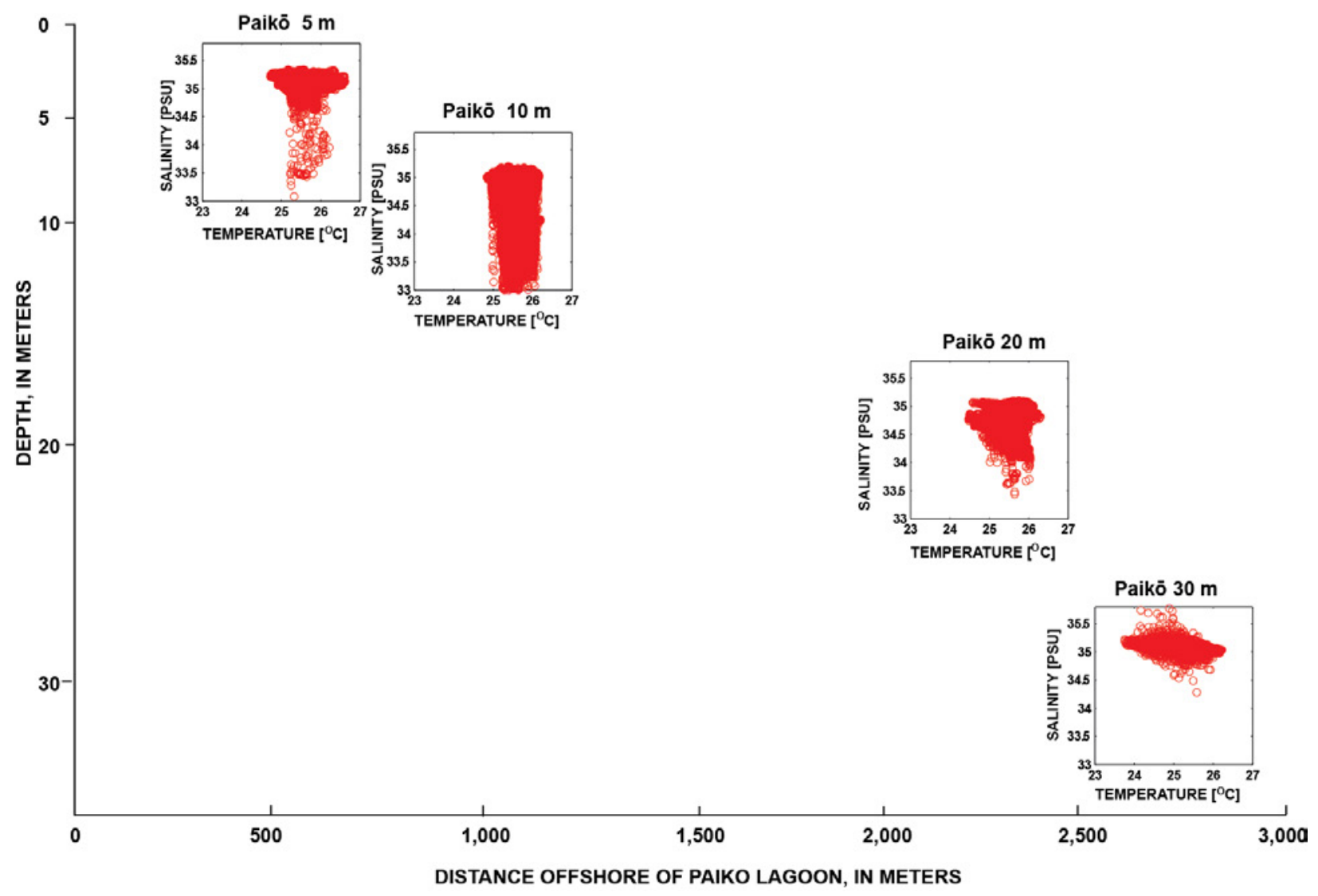

Figure 6. Scatter plot showing the relationship between water temperature, in degrees Celsius, and salinity, in Practical Salinity Units (PSU) along the cross-shore transect off Paikō from 5-m to 30-m water depth. Plots show the influence of freshwater close to shore at the shallow sites (lowered salinities) and possibly the influence of internal waves at the deepest site (colder, saltier observations). 


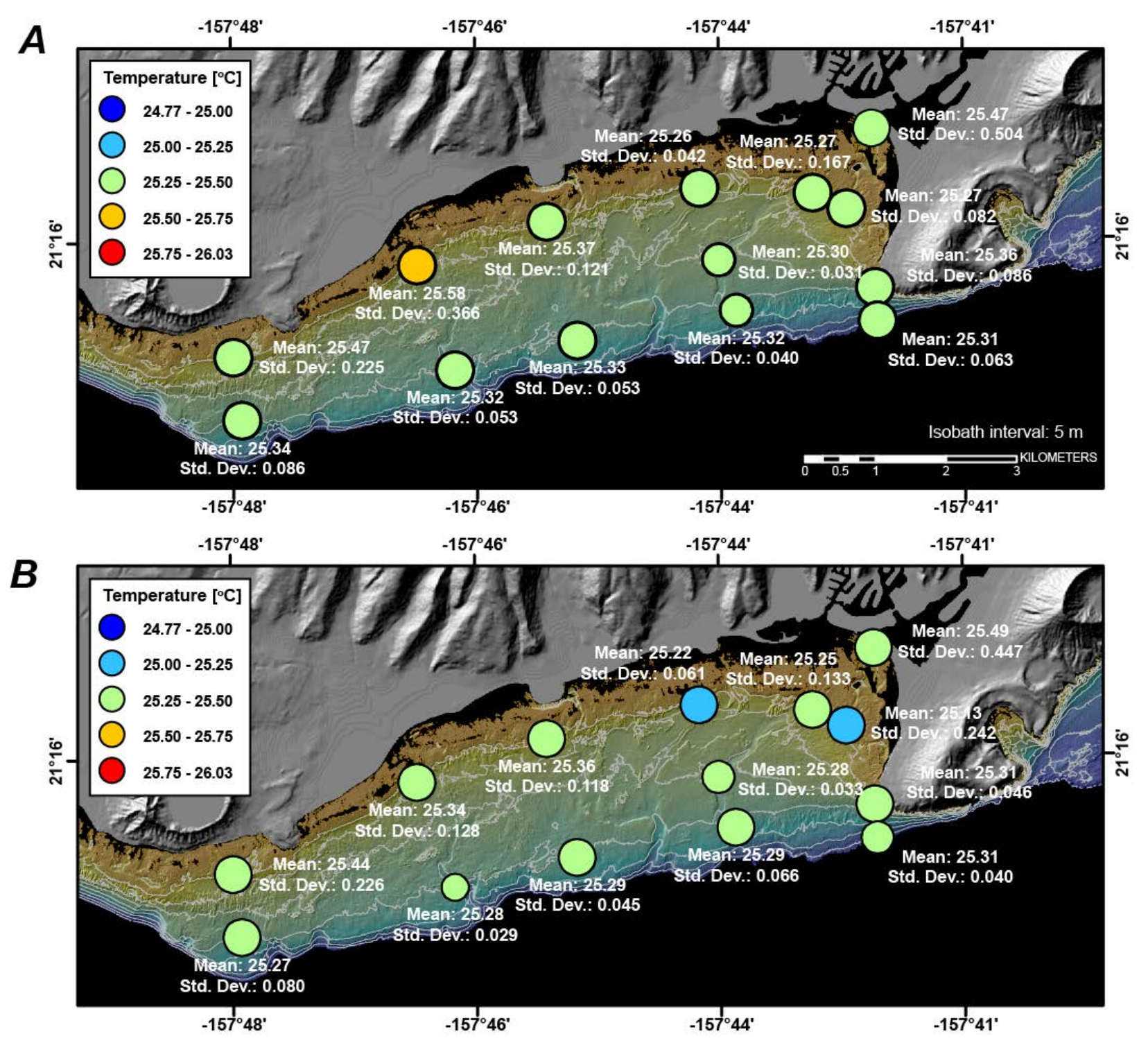

Figure 7. Map showing the spatial variability in temperature, in degrees Celsius, averaged from watercolumn profiler (WCP) surveys in Maunalua Bay made during the June 12-15 (2010 Year Days 162166) coral-spawning period. A, Averaged data from $1 \mathrm{~m}$ below the surface. $B$, Averaged data from $1 \mathrm{~m}$ above the seabed. The near-surface temperature data show very uniform temperature throughout the bay, with slightly warmer temperatures close to shore on the western side of the bay. The near-bed data show relatively uniform temperature data across the bay, with slightly cooler temperatures close to shore on the eastern side of the bay. In general, warmer temperatures were measured near the surface than close to the seabed, although the thermal stratification was small. 


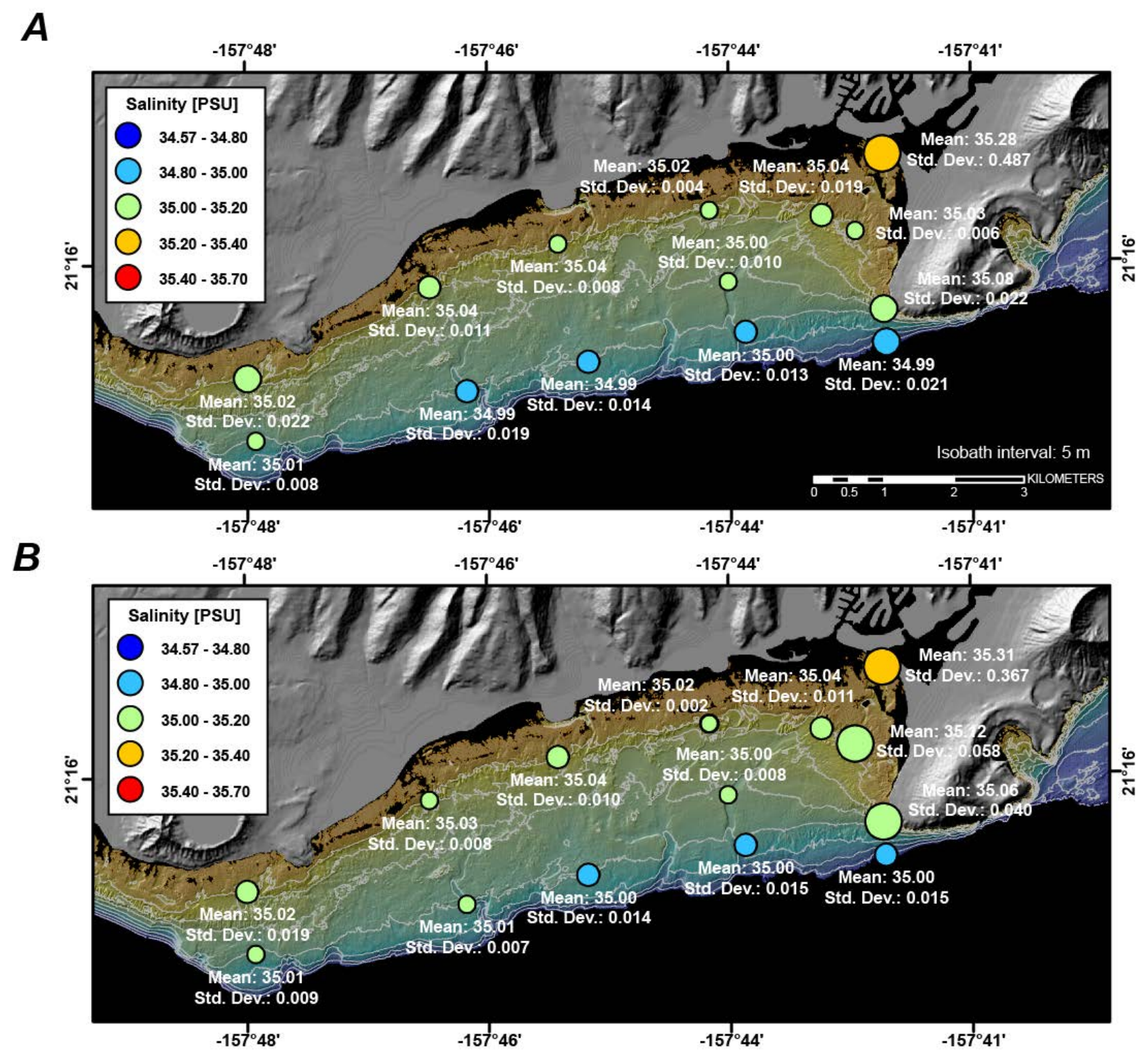

Figure 8. Map showing the spatial variability in salinity, in Practical Salinity Units (PSU), from the watercolumn profiler (WCP) surveys in Maunalua Bay averaged over the 4 days, June 12-15 (2010 Year Days 162-166) coral-spawning period. A, Averaged data from $1 \mathrm{~m}$ below the surface. $B$, Averaged data from $1 \mathrm{~m}$ above the seabed. The near-surface salinity was fairly uniform throughout the bay, with the highest salinity values observed close to shore, possibly because of evaporation. The near-bed salinity values were, in general, higher close to shore and near Hawai' $i$ Kai harbor. 


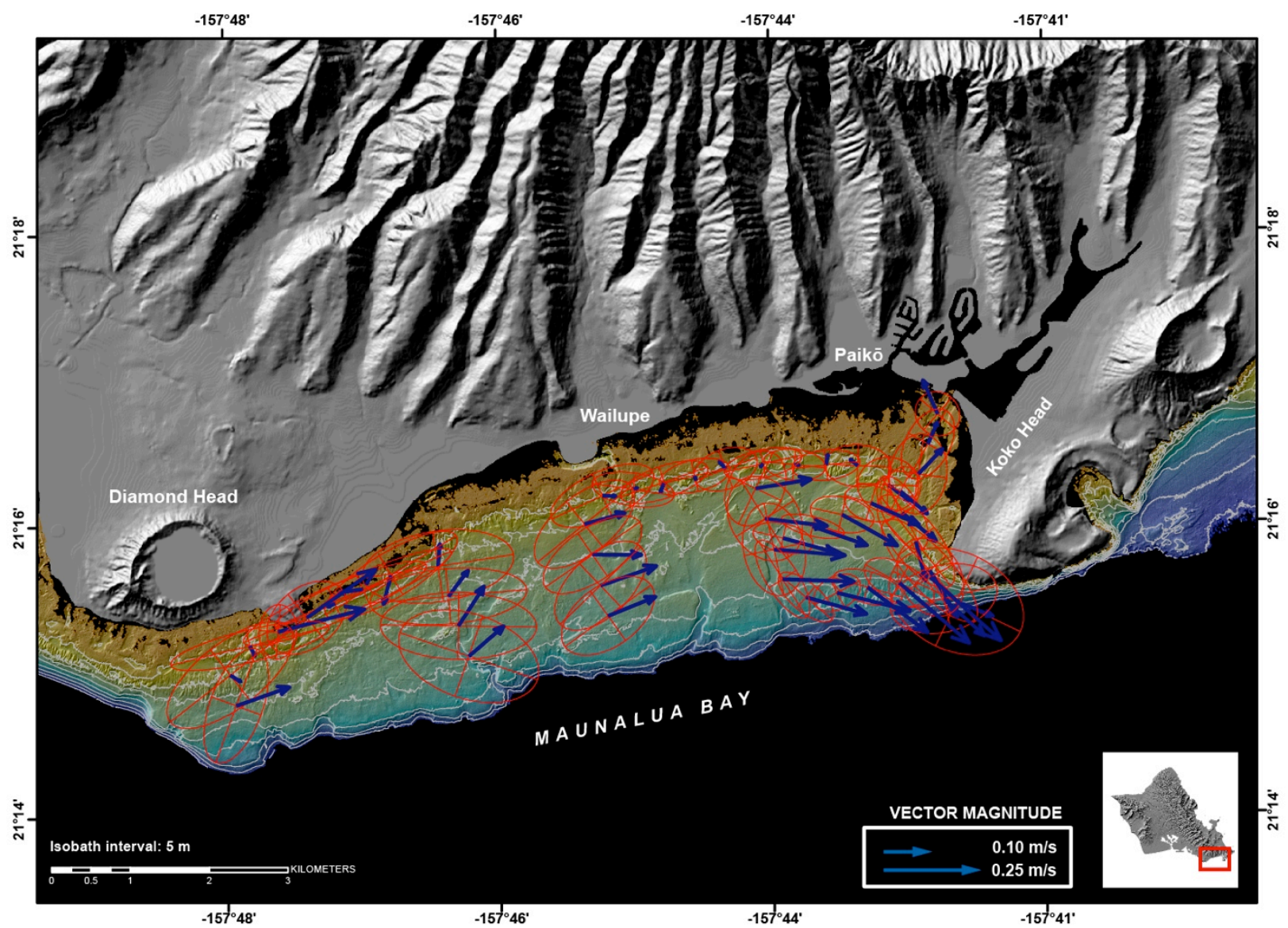

Figure 9. Map showing of mean current speeds and directions (arrows) and variability (ellipses), in meters per second from true north, for the vessel-mounted acoustic Doppler current-profiler (VMADCP) data from surveys during the June 12-15 (2010 Year Days 162-166) coral-spawning period, averaged at $400 \mathrm{~m}$ intervals along each VM-ADCP survey line. The predominant near-surface $(2 \mathrm{~m}$ below the surface) current direction for the four-day period was to the east for most of the bay. The near-surface currents closest to shore were the most variable and weak, with the fastest near-surface currents occurring in the middle of the bay and offshore. 


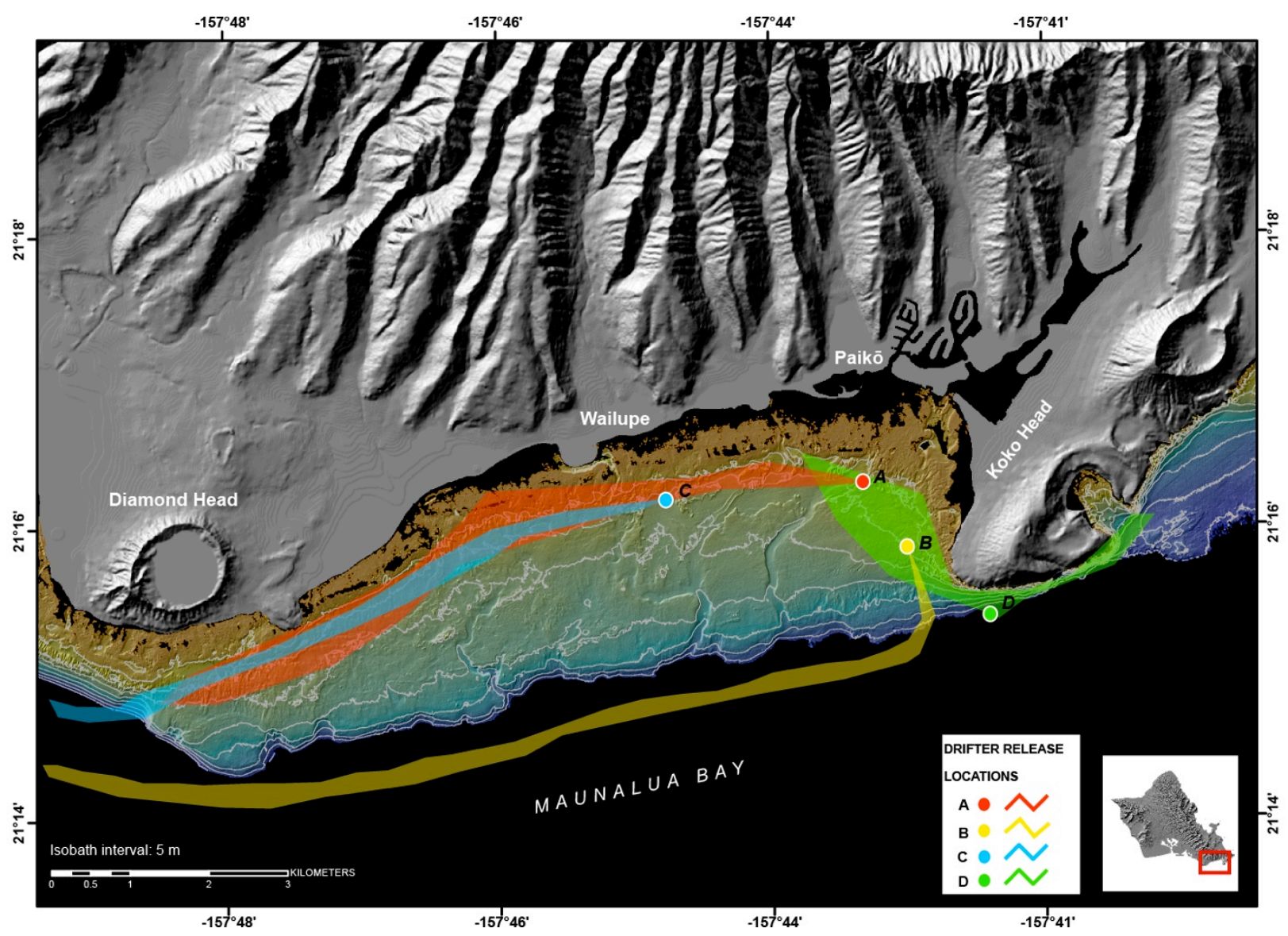

Figure 10. Map showing the areal extent of satellite drifters released from 4 locations (A-D) in Maunalua Bay over three nights June 12-15 (2010 Year Days 163-165) in Maunalua Bay following predicted times of coral-spawning in an attempt to track potential coral-larval dispersal. A, Inshore location on the east side of the bay near Hawai'i Kai harbor. B, Mid-shore location on the east side of the bay near Koko Head. C, Inshore location near Wailupe Peninsula. D, Offshore location near Koko Head. Most of the drifters that were released in the bay followed the tidal currents but ultimately traveled to the west toward Diamond Head, except for the drifter released offshore of Koko Head. This drifter traveled in and out of the bay, travelling as far as offshore of Hanauma Bay and then back into the eastern side of Maunalua Bay. 

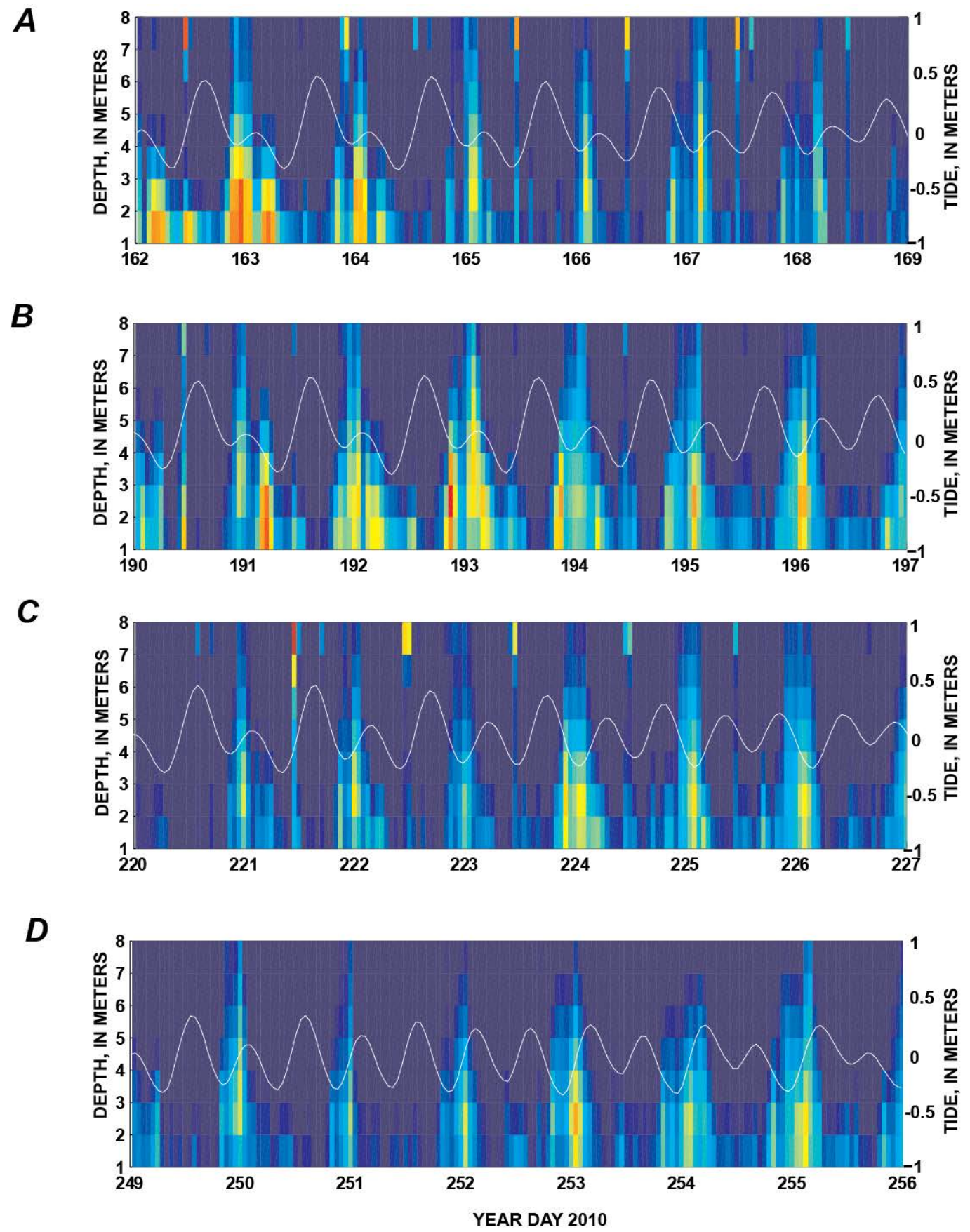

Figure 11. Time-series plots showing the vertical variation in acoustic Doppler current profiler (ADCP) acoustic backscatter data before, during, and after the 2010 summer predicted coral-spawning periods in Maunalua Bay and tide data from the Paiko 10-m site. A, Data from the June spawning period (2010 Year Days 162-166). B, Data from the July spawning period (2010 Year Days 191-195). C, Data from the August spawning period (2010 Year Days 221-225). D, Data from the September spawning period (2010 Year-Days 250-254). Relative abundance of coral larvae were detected by the ADCP's acoustic backscatter data, as shown by elevated acoustic backscatter (red, highest values; blue, lowest values) from the seabed up to the surface during the periods of spawning. Tidal stage is also shown for reference on each plot. 


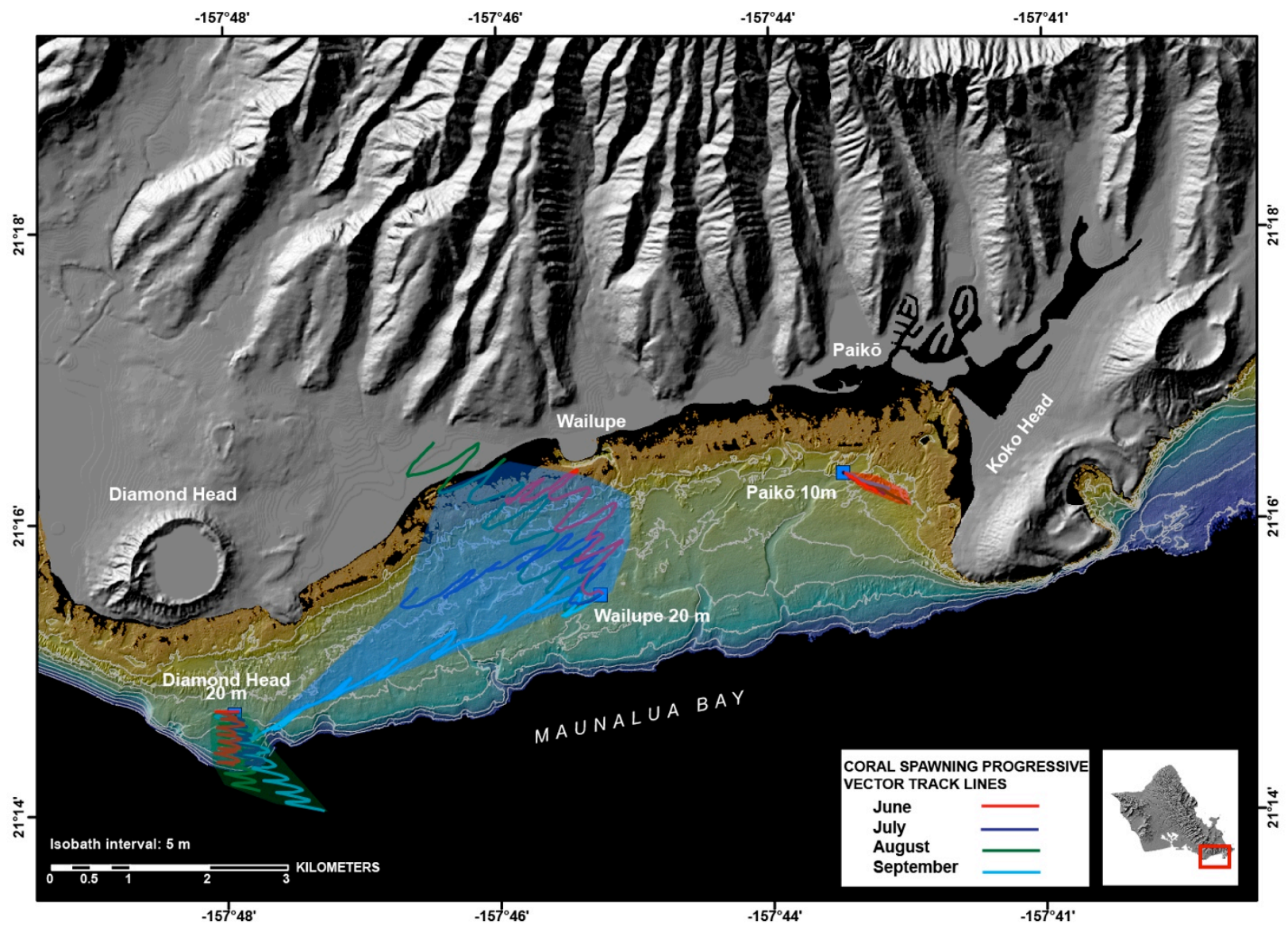

Figure 12. Map showing the areal extent of potential coral-larval dispersal (Storlazzi and others, 2006) from the Diamond Head 20-m (green), Wailupe 20-m (blue), and Paikō 10-m (red) sites during the 2010 summer predicted coral-spawning events in June, July, August, and September in Maunalua Bay. Note the similarities, and differences, between these data and the Lagrangian surface drifter tracks shown in figure 10. 


\section{Appendixes}

\section{Appendix 1. Acoustic Doppler Current Profiler (ADCP) Information}

RD Instruments 600-kHz Workhorse Monitor upward-looking acoustic Doppler current profiler s/n: 2074

Transmitting Frequency:

$614 \mathrm{kHz}$

Depth of Transducer:

$20 \mathrm{~m}$

Blanking Distance:

$0.25 \mathrm{~m}$

Height of First Bin above Transducer:

$1.45 \mathrm{~m}$

Bin Size:

Number of Bins:

$1.0 \mathrm{~m}$

Operating Mode:

24

Sampling Frequency:

High-resolution, broad bandwidth

Time per Ping:

$2 \mathrm{~Hz}$

Pings per Ensemble:

00:04.00

Profile Ensemble Interval:

75

Wave Ensemble Interval:

$0: 05: 00.00$

Sound Speed Calculation:

Set salinity, updating temperature by sensor

RD Instruments 600-kHz Workhorse Monitor upward-looking acoustic Doppler current profiler $\mathrm{s} / \mathrm{n}: 2432$

Transmitting Frequency:

$614 \mathrm{kHz}$

Depth of Transducer:

$16.5 \mathrm{~m}$

Blanking Distance:

$0.25 \mathrm{~m}$

Height of First Bin above Transducer: $\quad 1.45 \mathrm{~m}$

Bin Size:

$1.0 \mathrm{~m}$

Number of Bins:

24

Operating Mode:

High-resolution, broad bandwidth

Sampling Frequency:

$2 \mathrm{~Hz}$

Time per Ping:

00:04.00

Pings per Ensemble:

75

Profile Ensemble Interval:

$0: 05: 00.00$

Wave Ensemble Interval:

2:00:00.00

Sound Speed Calculation:

Set salinity, updating temperature by sensor 
RD Instruments 600-kHz Workhorse Monitor upward-looking acoustic Doppler current profiler s/n: 7447

Transmitting Frequency:

$614 \mathrm{kHz}$

Depth of Transducer:

$10 \mathrm{~m}$

Blanking Distance:

$0.25 \mathrm{~m}$

Height of First Bin above Transducer:

$1.45 \mathrm{~m}$

Bin Size:

$1.0 \mathrm{~m}$

Number of Bins:

12

Operating Mode:

High-resolution, broad bandwidth

Sampling Frequency:

$2 \mathrm{~Hz}$

Time per Ping:

00:04.00

Pings per Ensemble: $\quad 100$

Profile Ensemble Interval: $\quad$ 0:05:00.00

Wave Ensemble Interval: $\quad$ 2:00:00.00

Sound Speed Calculation: Set salinity, updating temperature by sensor

Nortek Instruments 1-MHz AWAC upward-looking acoustic Doppler current profiler $\mathrm{s} / \mathrm{n}: 5471$

Transmitting Frequency:

Depth of Transducer:

Blanking Distance:

Height of First Bin above Bed:

Bin Size:

Number of Bins:

Average interval:

Profile interval:

Wave interval:

Wave cell size:

Operating Mode:

Sound Speed Calculation:
$1 \mathrm{MHz}$

$20 \mathrm{~m}$

$0.50 \mathrm{~m}$

$1.50 \mathrm{~m}$

$1.00 \mathrm{~m}$

24

$0: 07: 30.00$

$0: 10: 00.00$

$1: 00: 00.00$

$2.4 \mathrm{~m}$

High-resolution

Set salinity, updating temperature via sensor

\section{Data Processing:}

The RD Instruments current data were processed using the WinADCP program and the wave data using the WavesMon program. The Nortek current data were processed using the Prof2NDP program and the wave data using the QuickWave program.

The data were averaged over 1 hour ensembles, all of the spurious data above the water surface were removed and all of the data in bins where the beam correlation dropped below $80 \%$ were removed for visualization and analysis. 


\section{Appendix 2. Conductivity and Temperature (CT) Information}

Seabird Microcat SBE-37SM temperature-conductivity (CT) sensors

s/n: 3800, 3801, 4368, 4369, 7046, and 7047

Sampling Frequency:

$2 \mathrm{~Hz}$

Measurements per Burst:

4

Time Between Bursts:

00:05:00.00

Data Processing:

The CT data were post-processed for visualization and analysis by removing all instantaneous (only one data point in time) data spikes that exceeded the deployment mean +3 standard deviations.

\section{Appendix 3. Weather Station (WS) Information}

NovaLynx WS-16N-A Marine-grade Weather Station:

Anemometer:

Temperature \& Relative Humidity:

Barometric Pressure Sensor:

Rain Gauge:

Sampling Frequency:

Measurements per Burst:

Time Between Bursts:

200-05106-MA (marine model)

110-WS-16TH-A w/radiation shield

110-WS-16BP

110-WS-16RC

$1 \mathrm{~Hz}$

1,500

00:30:00.00

\section{Appendix 4. Water-Column Profiler (WCP) Information}

Conductivity/Temperature/Depth (CTD) Profiler with Optical Backscatter (OBS),

Photosynthetically-Available Radiation (PAR), Dissolved Oxygen (DO), and

Chlorophyll (chl) Sensors

Instruments:

Seabird 19plus CTD sensor; $\mathrm{s} / \mathrm{n}$ :

D\&A Instruments OBS-3 sensor; $\mathrm{s} / \mathrm{n}$ : 1135

Seabird pressure sensor; $\mathrm{s} / \mathrm{n}$ : 2632709

Wet Labs CStar; s/n: $\quad 712$

Sampling Frequency: $\quad 4 \mathrm{~Hz}$

Position Information:

Garmin GPS-76 GPS; s/n: 80207465; USGS/CRP unit\#1

Data Processing:

The profiler data were processed using the SBEDataProcessing program.

The data were averaged into $0.5 \mathrm{~m}$ vertical bins and all of the spurious data marked by a flag in the raw data were removed for visualization and analysis. Stratification were measured as the difference between the mean of the top three bins ( $0.5-1.5 \mathrm{~m}$ below the surface) and the bottom three bins $(0.5-1.5 \mathrm{~m}$ above the bed). 
Appendix 5. Water-Column Profiler (WCP) log, June 2010

\begin{tabular}{|c|c|c|c|c|c|}
\hline \begin{tabular}{|l|} 
Cast \\
Number/Site \\
\end{tabular} & $\begin{array}{c}\text { Date } \\
\text { [MM/DD/YYY] }\end{array}$ & $\begin{array}{c}\text { Time } \\
{[\mathrm{HST}]}\end{array}$ & $\begin{array}{c}\text { Latitude } \\
\text { [decimal degrees] }\end{array}$ & $\begin{array}{c}\text { Longitude } \\
\text { [decimal degrees] }\end{array}$ & $\begin{array}{c}\text { Depth } \\
{[\mathrm{m}]}\end{array}$ \\
\hline 1 & $06 / 12 / 2010$ & 09:19:07 & 21.25573 & -157.711634 & 36.9 \\
\hline 2 & 06/12/2010 & $09: 42: 15$ & 21.27250 & -157.719923 & 6.4 \\
\hline 3 & 06/12/2010 & $10: 26: 19$ & 21.27292 & -157.736445 & 7.1 \\
\hline 4 & 06/12/2010 & $10: 34: 39$ & 21.26427 & -157.733499 & 18.1 \\
\hline 5 & $06 / 12 / 2010$ & $10: 53: 53$ & 21.27055 & -157.715829 & 4.4 \\
\hline 6 & $06 / 12 / 2010$ & 11:03:59 & 21.28028 & -157.712304 & 1.9 \\
\hline 7 & $06 / 12 / 2010$ & $11: 18: 24$ & 21.26060 & -157.712136 & 5.4 \\
\hline 8 & $06 / 12 / 2010$ & $11: 34: 59$ & 21.25768 & -157.731398 & 20.6 \\
\hline 9 & $06 / 12 / 2010$ & $11: 51: 50$ & 21.27289 & -157.736287 & 7.1 \\
\hline 10 & 06/12/2010 & 12:10:45 & 21.26912 & -157.756957 & 5.9 \\
\hline 11 & 06/12/2010 & $12: 26: 22$ & 21.25406 & -157.752922 & 19.9 \\
\hline 12 & $06 / 12 / 2010$ & $12: 38: 20$ & 21.25028 & -157.769402 & 24.6 \\
\hline 13 & $06 / 12 / 2010$ & $12: 53: 21$ & 21.26302 & -157.774762 & 10.9 \\
\hline 14 & $06 / 12 / 2010$ & $13: 16: 12$ & 21.25175 & -157.799892 & 7.6 \\
\hline 15 & $06 / 12 / 2010$ & $13: 27: 13$ & 21.24315 & -157.750340 & 22.1 \\
\hline 16 & 06/13/2010 & 08:36:07 & 21.24412 & -157.797837 & 15.4 \\
\hline 17 & 06/13/2010 & 08:46:56 & 21.25191 & -157.799873 & 6.1 \\
\hline 18 & 06/13/2010 & $09: 13: 29$ & 21.26388 & -157.774500 & 5.9 \\
\hline 19 & $06 / 13 / 2010$ & $09: 28: 29$ & 21.25023 & -157.769893 & 23.1 \\
\hline 20 & 06/13/2010 & 09:41:51 & 21.25361 & -157.752997 & 20.4 \\
\hline 21 & 06/13/2010 & 09:59:52 & 21.26914 & -157.756860 & 5.4 \\
\hline 22 & 06/13/2010 & $10: 21: 24$ & 21.27347 & -157.735662 & 3.9 \\
\hline 23 & 06/13/2010 & $10: 39: 33$ & 21.25733 & -157.731310 & 21.1 \\
\hline 24 & 06/13/2010 & 10:59:57 & 21.26056 & -157.712052 & 5.1 \\
\hline 25 & 06/13/2010 & $11: 17: 45$ & 21.28019 & -157.712175 & 2.4 \\
\hline 26 & 06/13/2010 & $11: 27: 34$ & 21.27056 & -157.715975 & 5.4 \\
\hline 27 & 06/13/2010 & 11:43:56 & 21.26383 & -157.733745 & 18.9 \\
\hline 28 & $06 / 13 / 2010$ & $12: 07: 51$ & 21.27294 & -157.721457 & 5.4 \\
\hline 29 & 06/13/2010 & $12: 25: 29$ & 21.25687 & -157.712139 & 32.1 \\
\hline 30 & 06/14/2010 & 09:30:28 & 21.25602 & -157.711589 & 37.6 \\
\hline 31 & 06/14/2010 & 09:50:51 & 21.27168 & -157.719714 & 5.4 \\
\hline 32 & 06/14/2010 & 10:07:11 & 21.27342 & -157.736055 & 4.9 \\
\hline 33 & $06 / 14 / 2010$ & $10: 14: 40$ & 21.26406 & -157.733364 & 18.1 \\
\hline 34 & 06/14/2010 & $10: 35: 21$ & 21.27041 & -157.716249 & 5.4 \\
\hline 35 & 06/14/2010 & $10: 47: 21$ & 21.28051 & -157.712169 & 1.1 \\
\hline 36 & 06/14/2010 & 11:03:37 & 21.26038 & -157.712024 & 5.6 \\
\hline 37 & 06/14/2010 & 11:21:46 & 21.25761 & -157.730646 & 20.9 \\
\hline 38 & 06/14/2010 & 12:00:18 & 21.26931 & -157.756982 & 4.9 \\
\hline 39 & $06 / 14 / 2010$ & $12: 17: 51$ & 21.25397 & -157.752879 & 19.9 \\
\hline 40 & $06 / 14 / 2010$ & $12: 31: 53$ & 21.25024 & -157.769337 & 24.9 \\
\hline 41 & 06/14/2010 & $12: 49: 48$ & 21.26360 & -157.774937 & 6.4 \\
\hline 42 & 06/14/2010 & 13:18:13 & 21.25210 & -157.799914 & 7.4 \\
\hline 43 & 06/14/2010 & $13: 27: 36$ & 21.24414 & -157.798911 & 20.4 \\
\hline 44 & 06/15/2010 & 08:56:08 & 21.24423 & -157.799100 & 19.9 \\
\hline 45 & $06 / 15 / 2010$ & 09:08:29 & 21.25233 & -157.800075 & 4.1 \\
\hline 46 & $06 / 15 / 2010$ & $09: 35: 26$ & 21.26398 & -157.774537 & 5.9 \\
\hline 47 & 06/15/2010 & $09: 51: 38$ & 21.24998 & -157.769916 & 20.4 \\
\hline 48 & 06/15/2010 & 10:06:09 & 21.25389 & -157.752797 & 20.1 \\
\hline 49 & $06 / 15 / 2010$ & $10: 25: 32$ & 21.26886 & -157.756978 & 5.9 \\
\hline 50 & $06 / 15 / 2010$ & 10:58:39 & 21.27362 & -157.735817 & 6.1 \\
\hline 51 & $06 / 15 / 2010$ & 11:17:33 & 21.25756 & -157.731307 & 20.9 \\
\hline 52 & $06 / 15 / 2010$ & $11: 36: 56$ & 21.26013 & -157.712311 & 12.1 \\
\hline
\end{tabular}




\section{Appendix 5. Water-Column Profiler (WCP) log, June 2010-Continued}

\begin{tabular}{|l|c|c|c|c|c|}
\hline $\begin{array}{l}\text { Cast } \\
\text { Number/Site }\end{array}$ & $\begin{array}{c}\text { Date } \\
\text { [MM/DD/YYY] }\end{array}$ & $\begin{array}{c}\text { Time } \\
{[\mathrm{HST}]}\end{array}$ & $\begin{array}{c}\text { Latitude } \\
\text { [decimal degrees] }\end{array}$ & $\begin{array}{c}\text { Longitude } \\
\text { [decimal degrees] }\end{array}$ & $\begin{array}{c}\text { Depth } \\
{[\mathrm{m}]}\end{array}$ \\
\hline 53 & $06 / 15 / 2010$ & $11: 53: 39$ & 21.28065 & -157.712155 & 1.4 \\
54 & $06 / 15 / 2010$ & $12: 04: 02$ & 21.27056 & -157.715854 & 4.4 \\
55 & $06 / 15 / 2010$ & $12: 22: 47$ & 21.26409 & -157.733478 & 18.4 \\
56 & $06 / 15 / 2010$ & $12: 46: 36$ & 21.27317 & -157.721260 & 5.4 \\
57 & $06 / 15 / 2010$ & $13: 06: 01$ & 21.25603 & -157.711875 & 37.1 \\
\hline
\end{tabular}


Appendix 6. Time-series Plots of Variations in Water Level, Wave Heights, Wave Periods, and Wave Directions from Acoustic Doppler Current Profilers (ADCPs) in Maunalua Bay for 2010 Year Days 163-256 (June 12-September 13)

Appendix 6.1. Tide and wave data from the ADCP at the Wailupe 20-m site. A, Tidal height, in meters. $B$, Wave height, in meters, with significant wave height in blue and maximum wave height in red. $C$, Wave period, in seconds, with mean wave period in blue and peak wave period in red. $D$, Wave height (red), in meters, and wave height and direction (blue), in meters from true north. Because of issues with the pressure sensor, wave data were only collected from 2010 Year Days 223-256 (August 11-September 13).

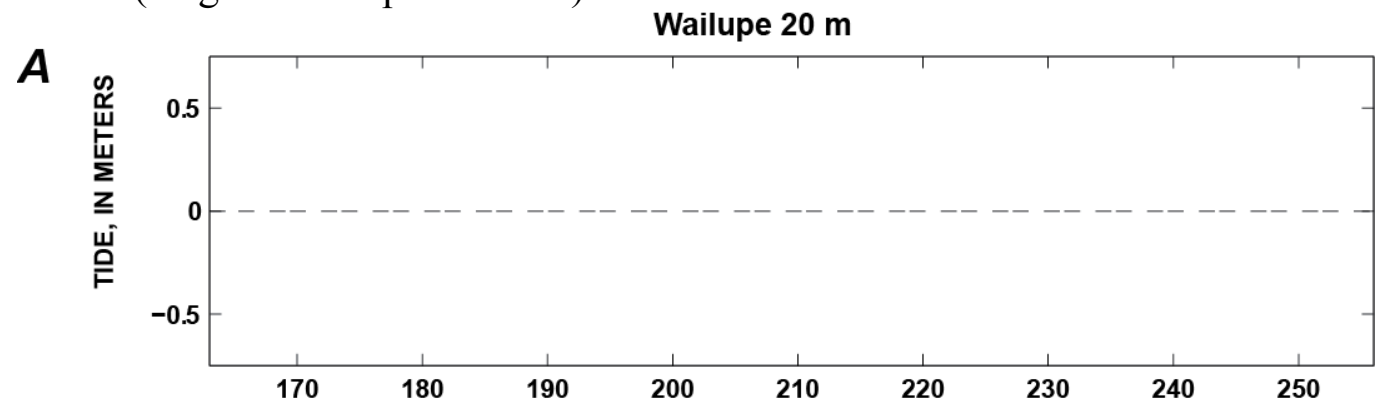

B

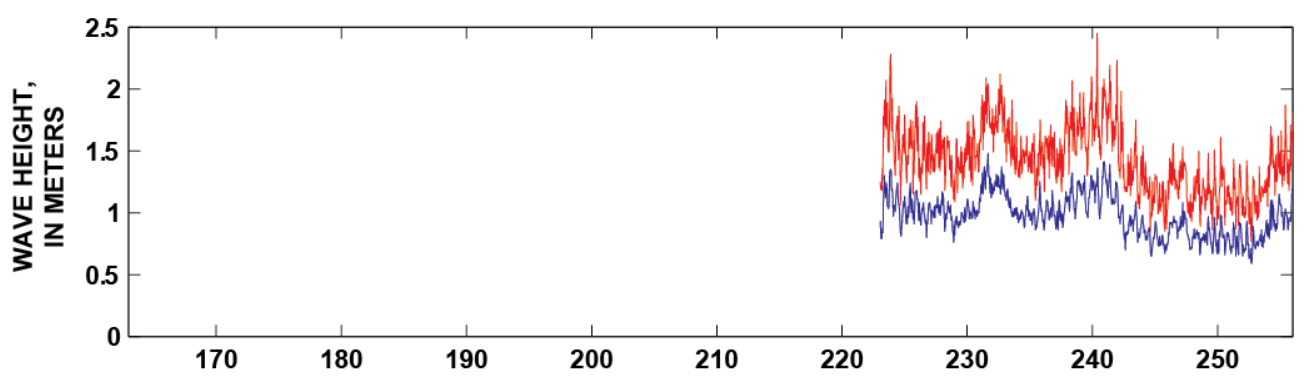

C

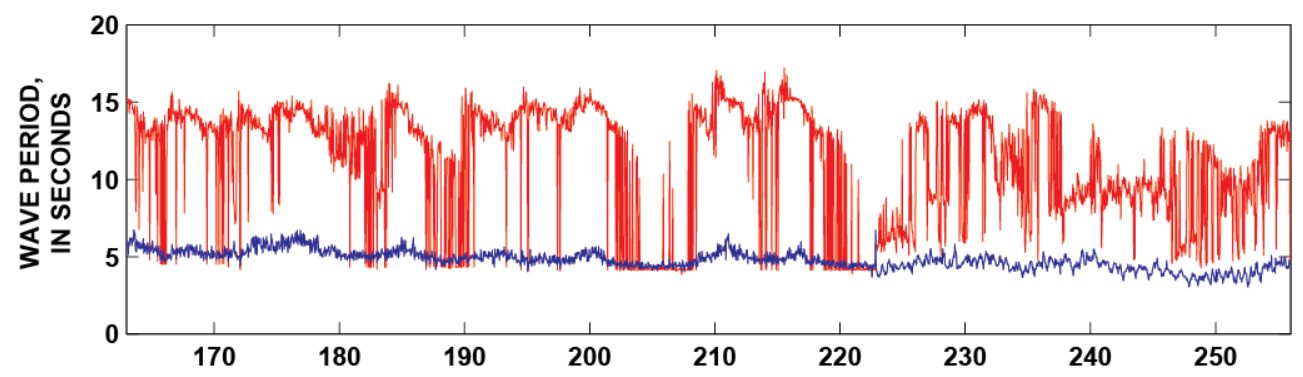

D

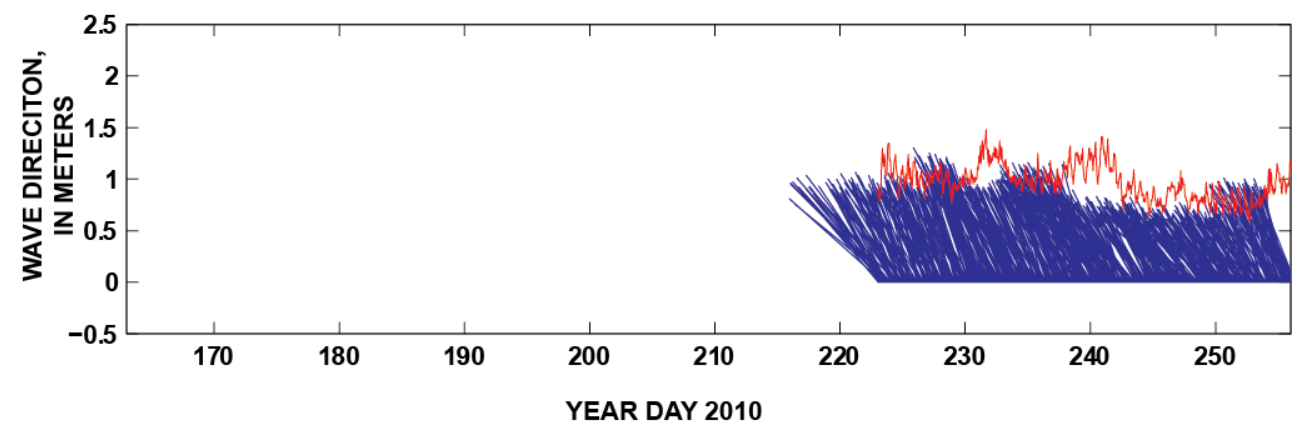


Appendix 6.2. Tide and wave data from the ADCP at the Diamond Head 20-m site. A, Tidal height, in meters. $B$, Wave height, in meters, with significant wave height in blue and maximum wave height in red. $C$, Wave period, in seconds, with mean wave period in blue and peak wave period in red. $D$, Wave height (red), in meters, and wave height and direction (blue), in meters from true north.

Diamond Head 20 m

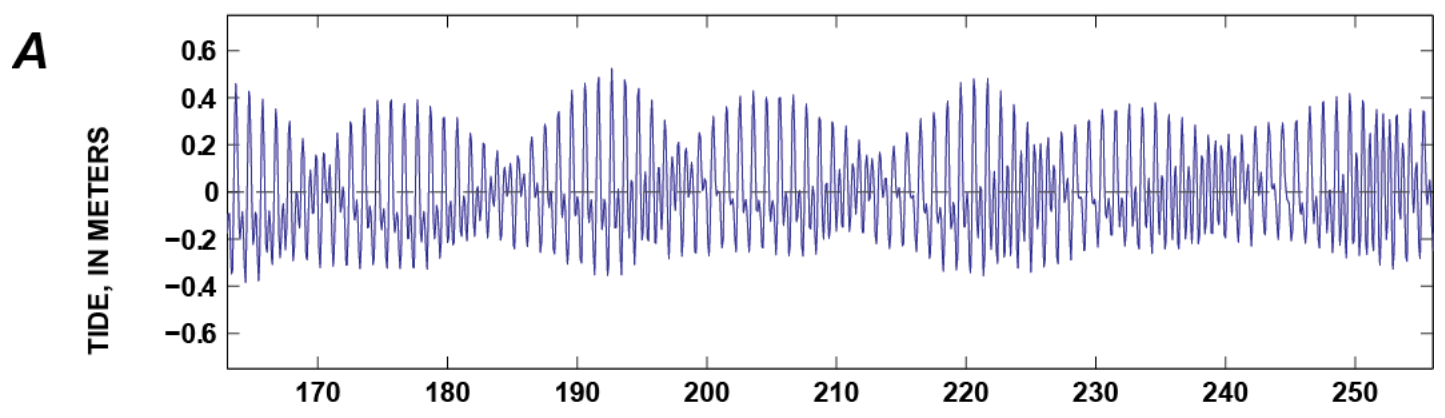

$B$

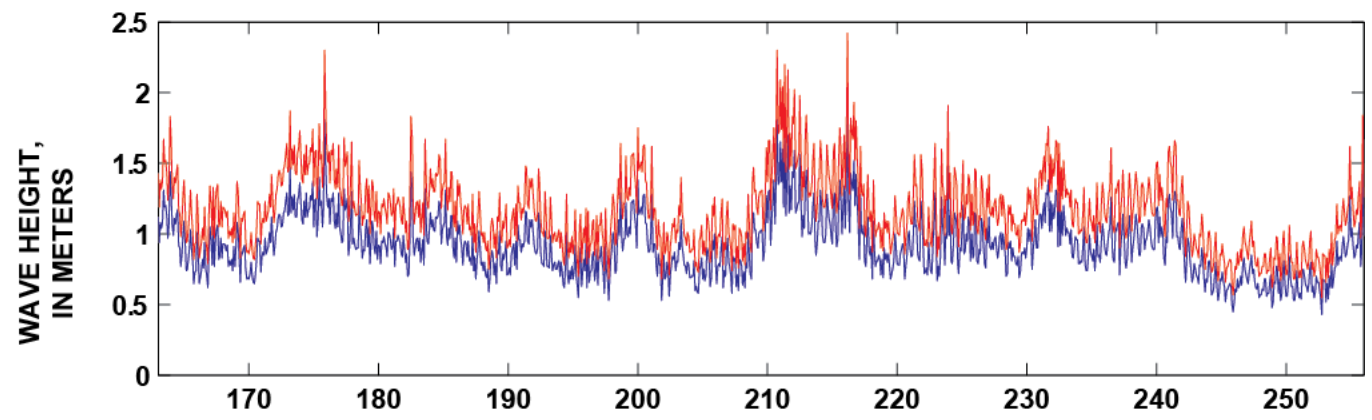

C

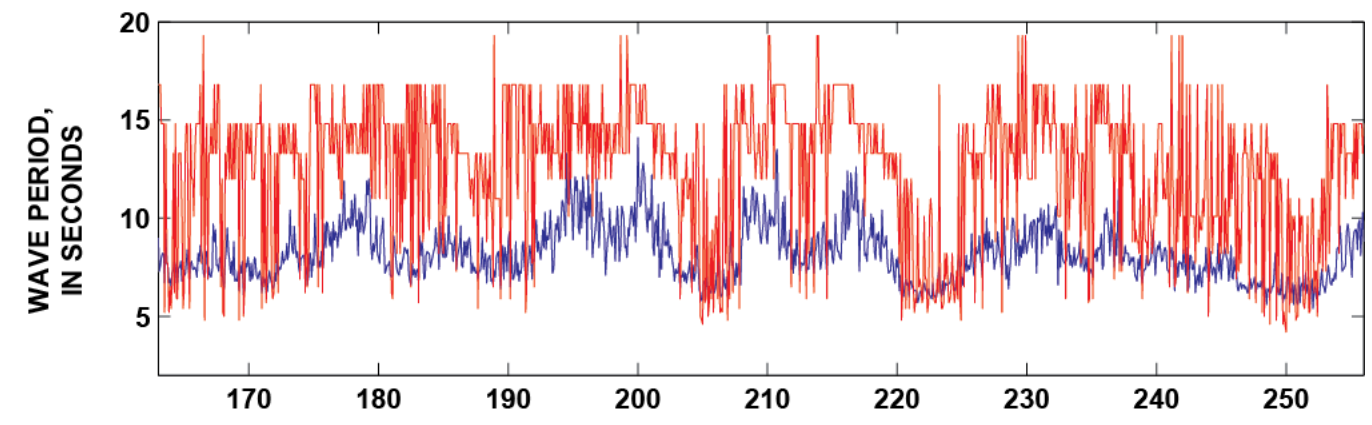

D

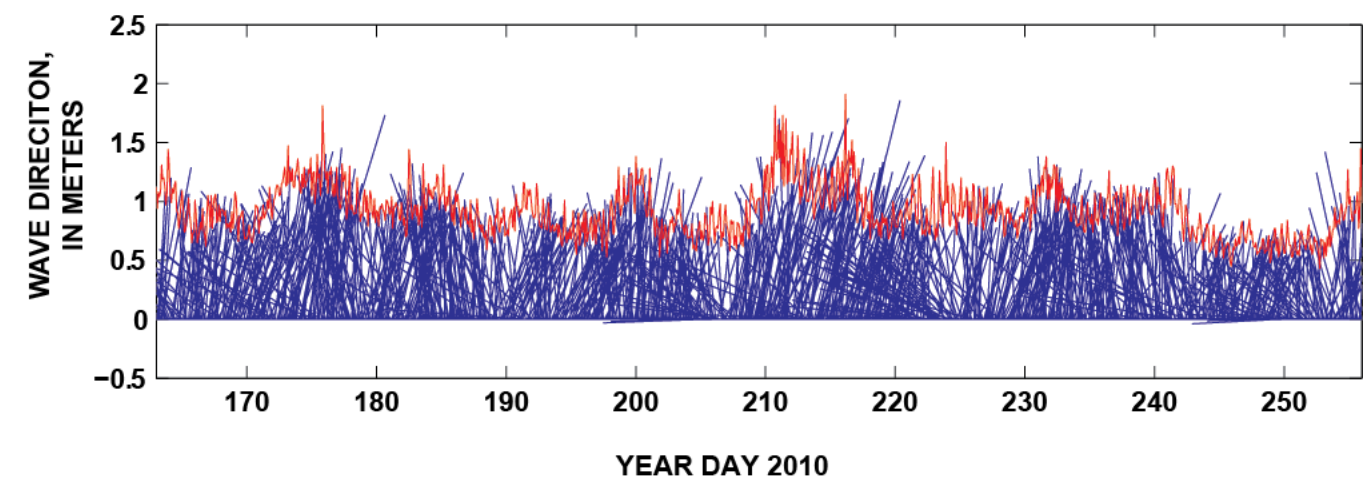


Appendix 6.3. Tide and wave data from the ADCP at the Paiko 10-m site. A, Tidal height, in meters. $B$, Wave height, in meters, with significant wave height in blue and maximum wave height in red. $C$, Wave period, in seconds, with mean wave period in blue and peak wave period in red. $D$, Wave height (red), in meters, and wave height and direction (blue), in meters from true north.

A

Paikō $10 \mathrm{~m}$

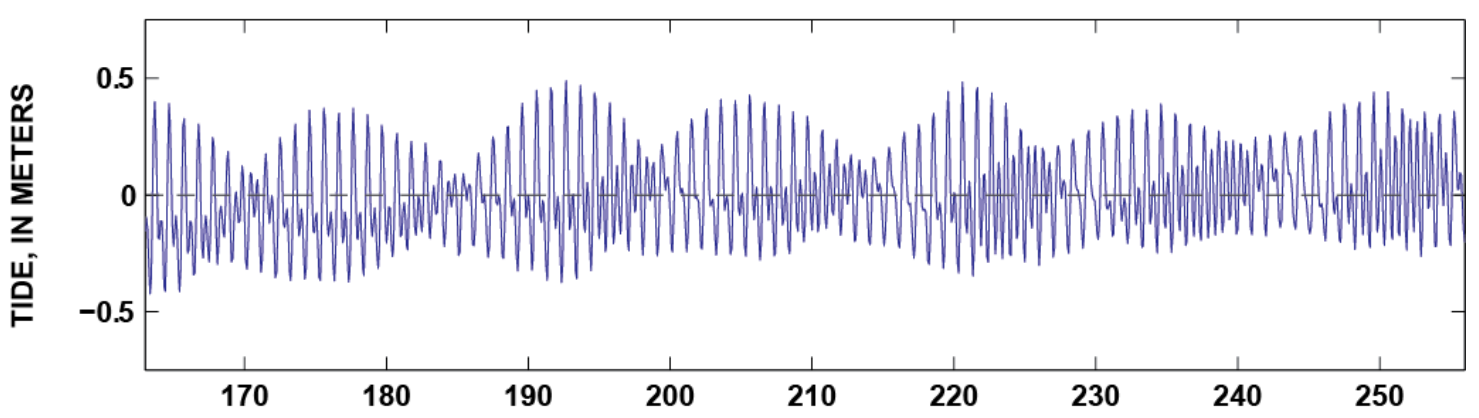

B

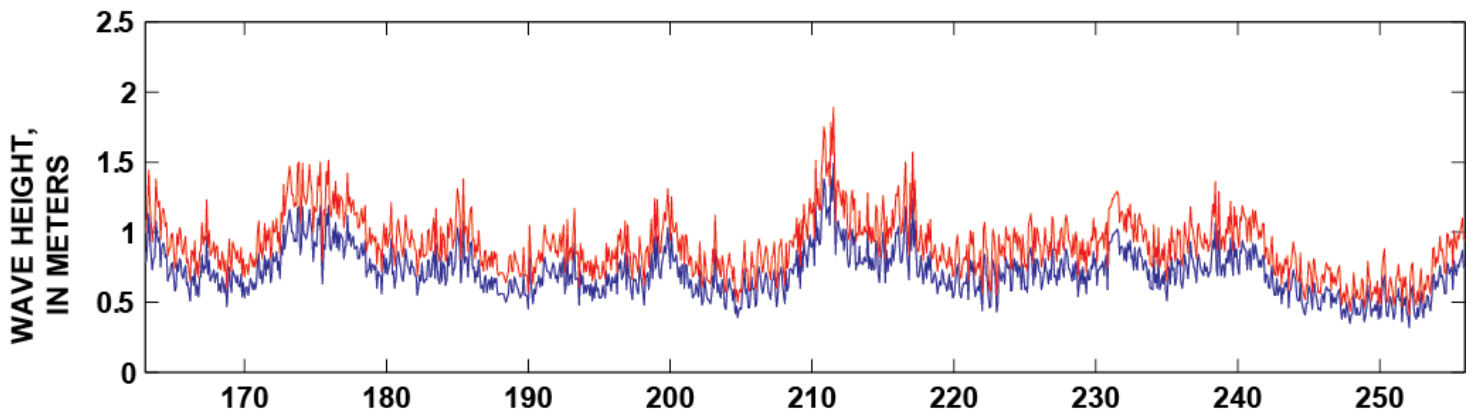

C

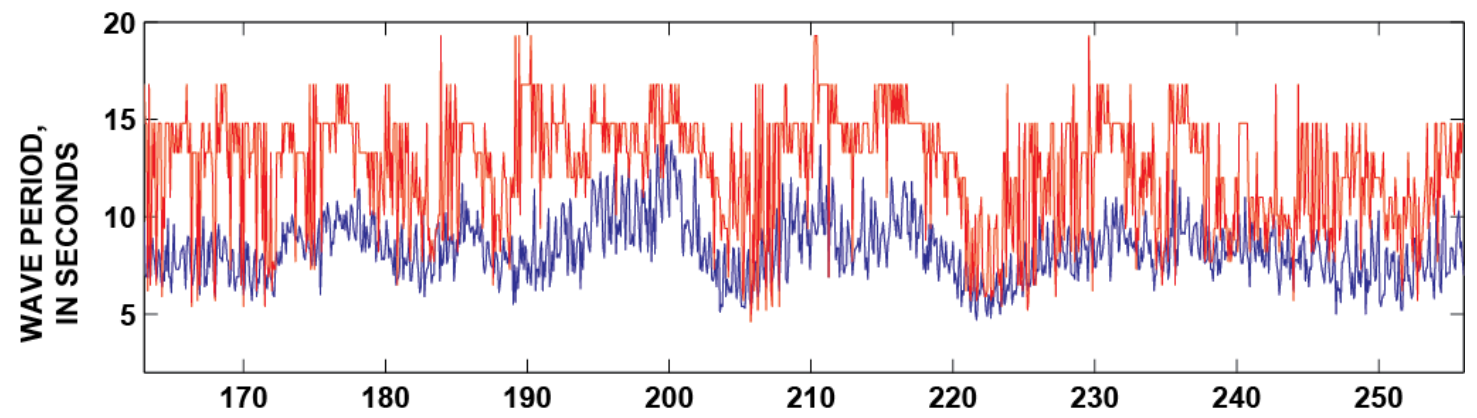

D

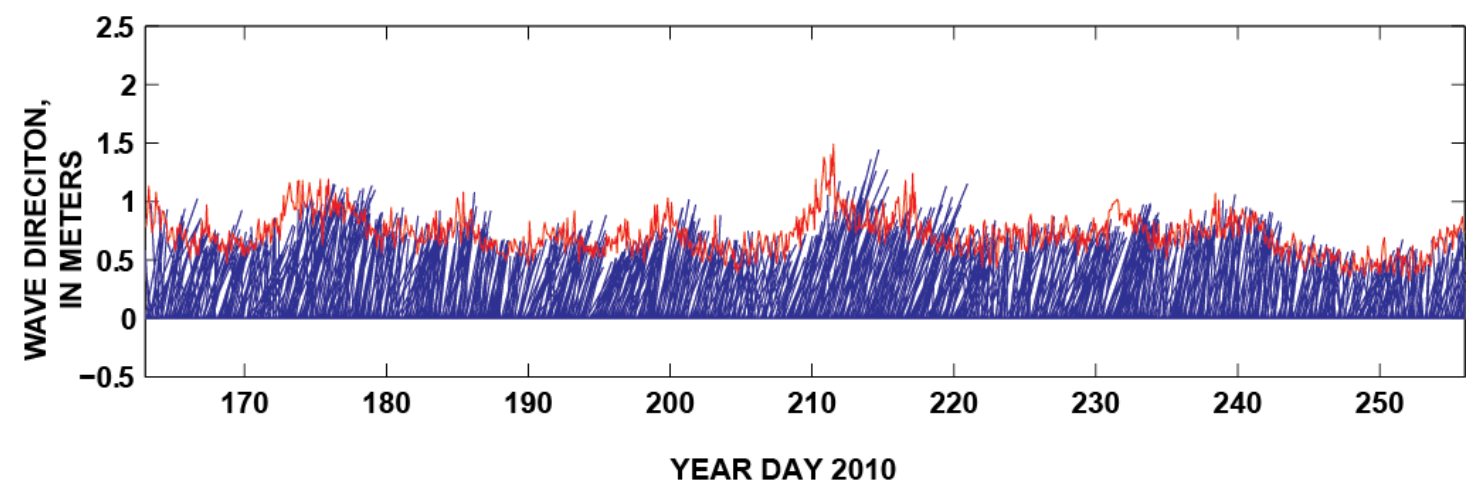


Appendix 7. Time-Series Plots of Variations In Water Level, Currents, and Temperature from Acoustic Doppler Current Profilers (ADCPs) in Maunalua Bay for 2010 Year Days 163-256 (June 12-September 13)

Appendix 7.1. Tide, current, and water temperature data from the ADCP at the Wailupe $20-\mathrm{m}$ site. $A$, Tidal height, in meters. $B$, Near-surface current speeds and directions, in meters per second from true north. $C$, Mid-depth current speeds and directions, in meters per second from true north. $D$, Near-bed current speeds and directions, in meters per second from true north. $E$, Temperature, in degrees Celsius. Because of issues with the pressure sensor, tidal data was not collected from this instrument.

Wailupe $20 \mathrm{~m}$
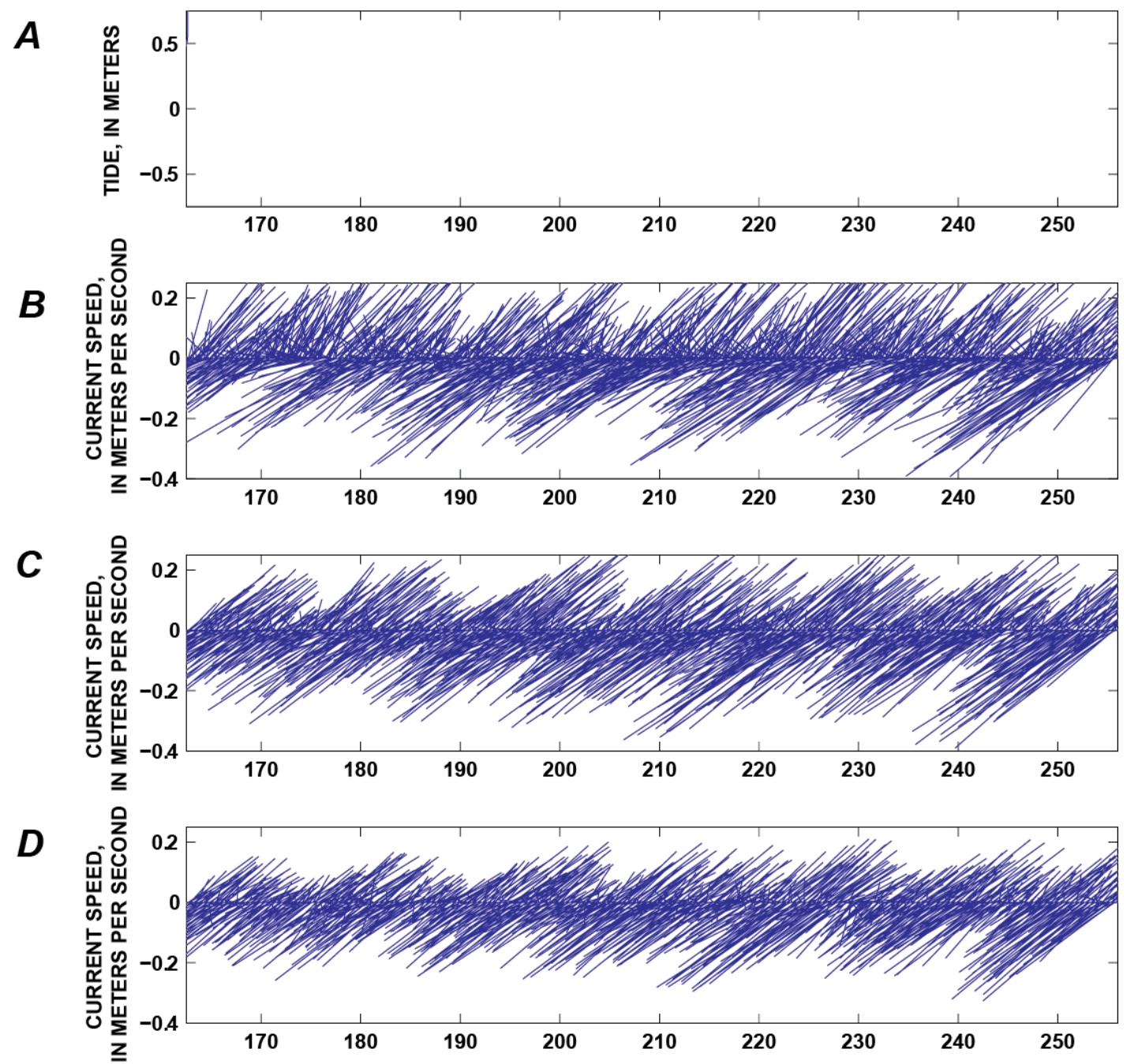

E

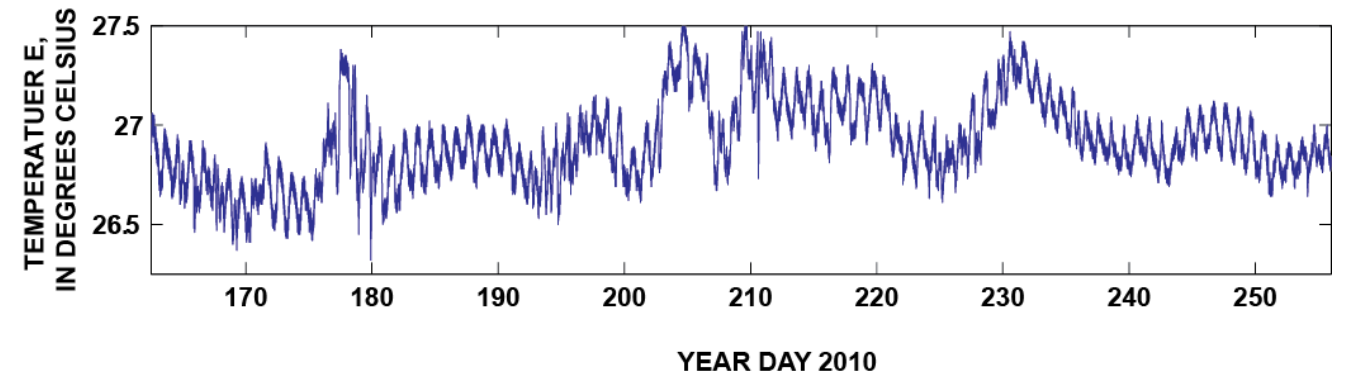


Appendix 7.2. Tide, current, and water temperature data from the ADCP at the Diamond Head 20 -m site. $A$, Tidal height, in meters. $B$, Near-surface current speeds and directions, in meters per second from true north. $C$, Mid-depth current speeds and directions, in meters per second from true north. $D$, Near-bed current speeds and directions, in meters per second from true north. $E$, Temperature, in degrees Celsius.

\section{Diamond Head $20 \mathrm{~m}$}
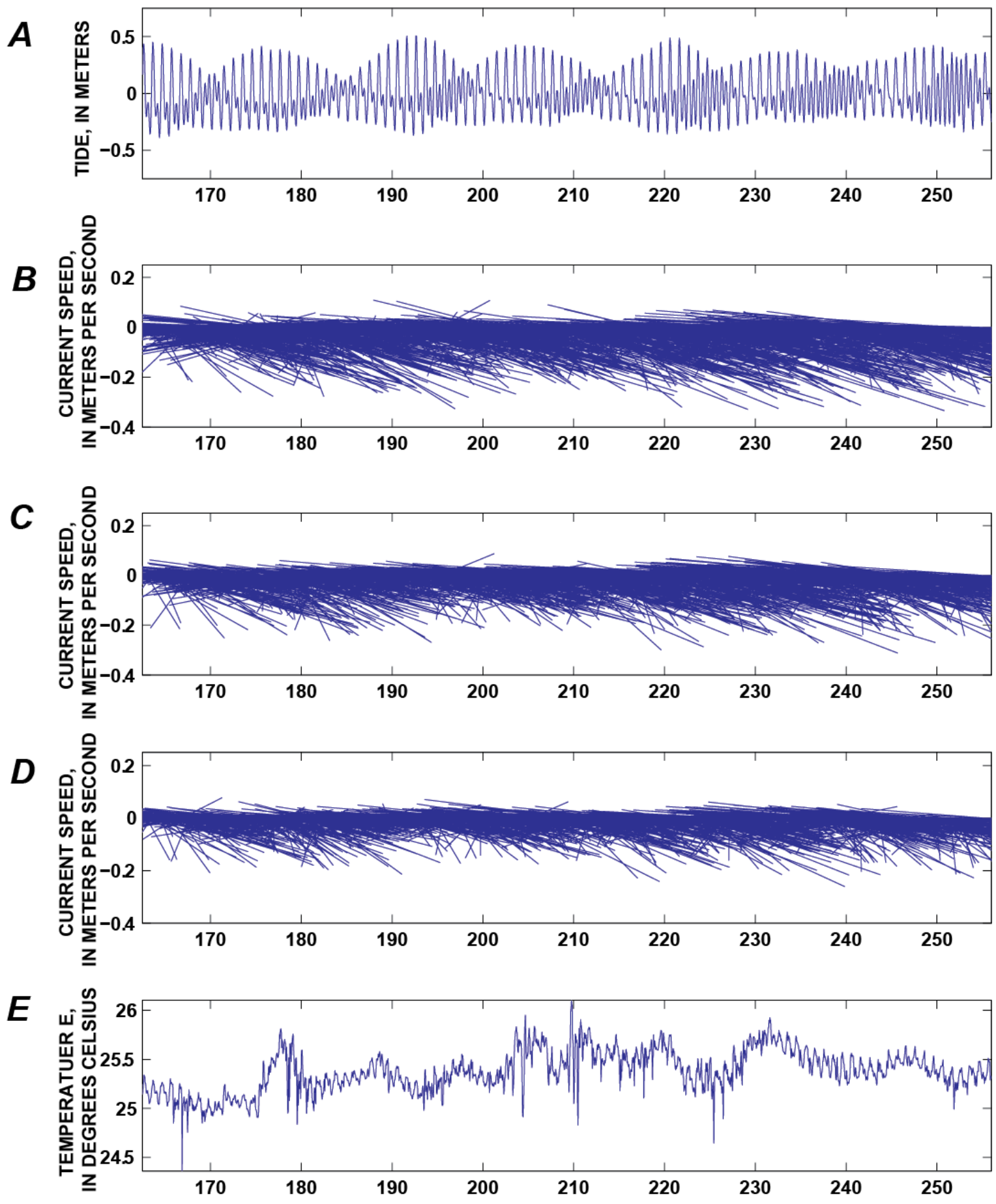

YEAR DAY 2010 
Appendix 7.3. Tide, current, and water temperature data from the ADCP at the Paikō-10 $\mathrm{m}$ site. $A$, Tidal height, in meters. $B$, Near-surface current speeds and directions, in meters per second from true north. $C$, Mid-depth current speeds and directions, in meters per second from true north. $D$, Near-bed current speeds and directions, in meters per second from true north. $E$, Water temperature, in degrees Celsius.

\section{Paikō $10 \mathrm{~m}$}
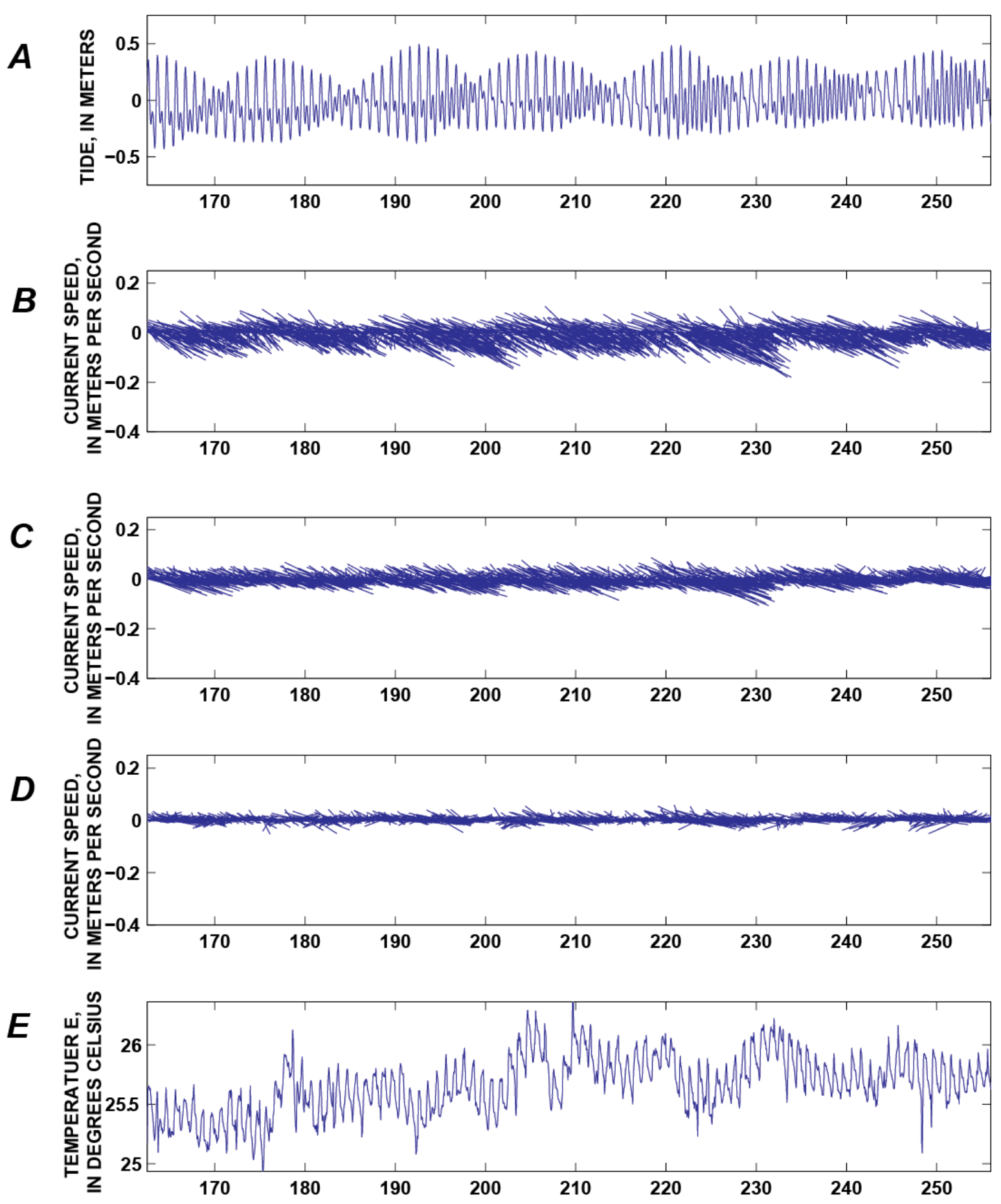

YEAR DAY 2010 
Appendix 8. Time-Series Plots of Variations in Temperature and Salinity from Conductivity/Temperature (CT) Sensors in Maunalua Bay for 2010 Year Days 163-256 (June 12-September 13)

Appendix 8.1. Temperature and salinity data from the $\mathrm{CT}$ at the Wailupe 20-m site. A, Water temperature, in degrees Celsius. B, Salinity, in Practical Salinity Units (PSU).

Wailupe $20 \mathrm{~m}$

$\boldsymbol{A}$

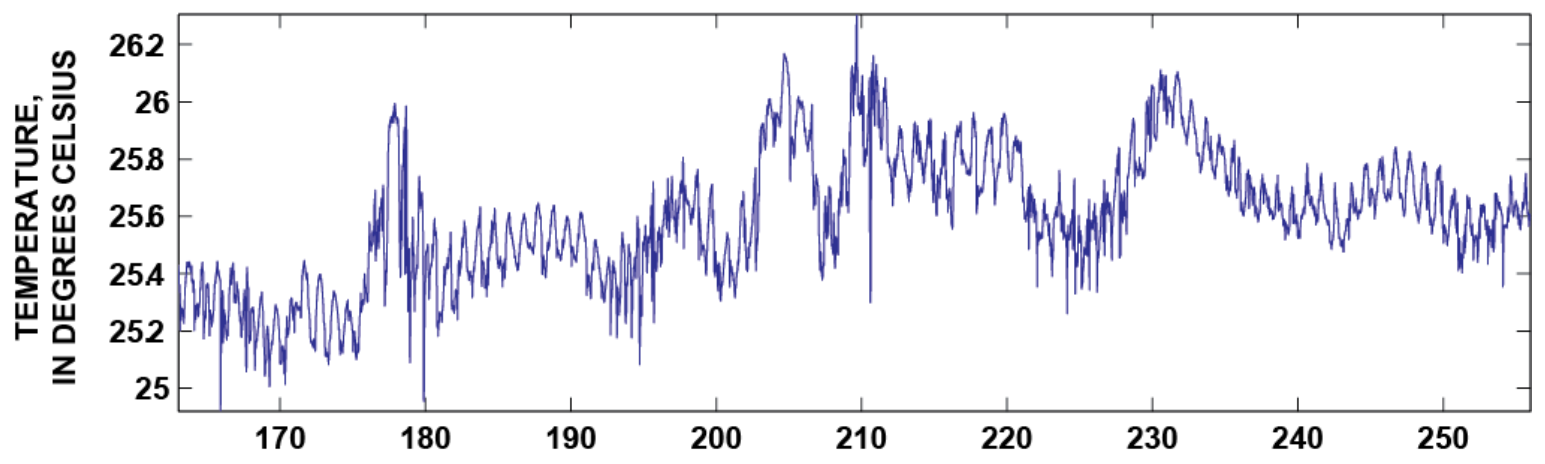

B

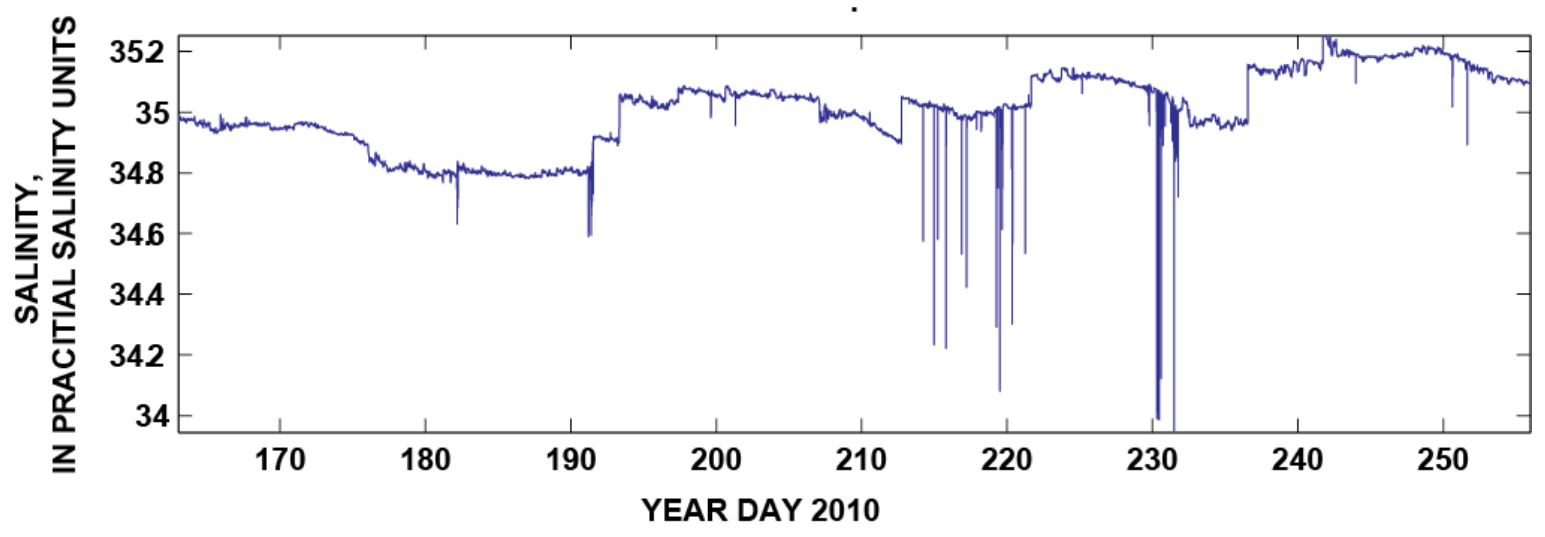


Appendix 8.2. Temperature and salinity data from the CT at the Diamond Head 20-m site. A, Water temperature, in degrees Celsius. $B$, Salinity, in Practical Salinity Units (PSU).

Diamond Head 20 m
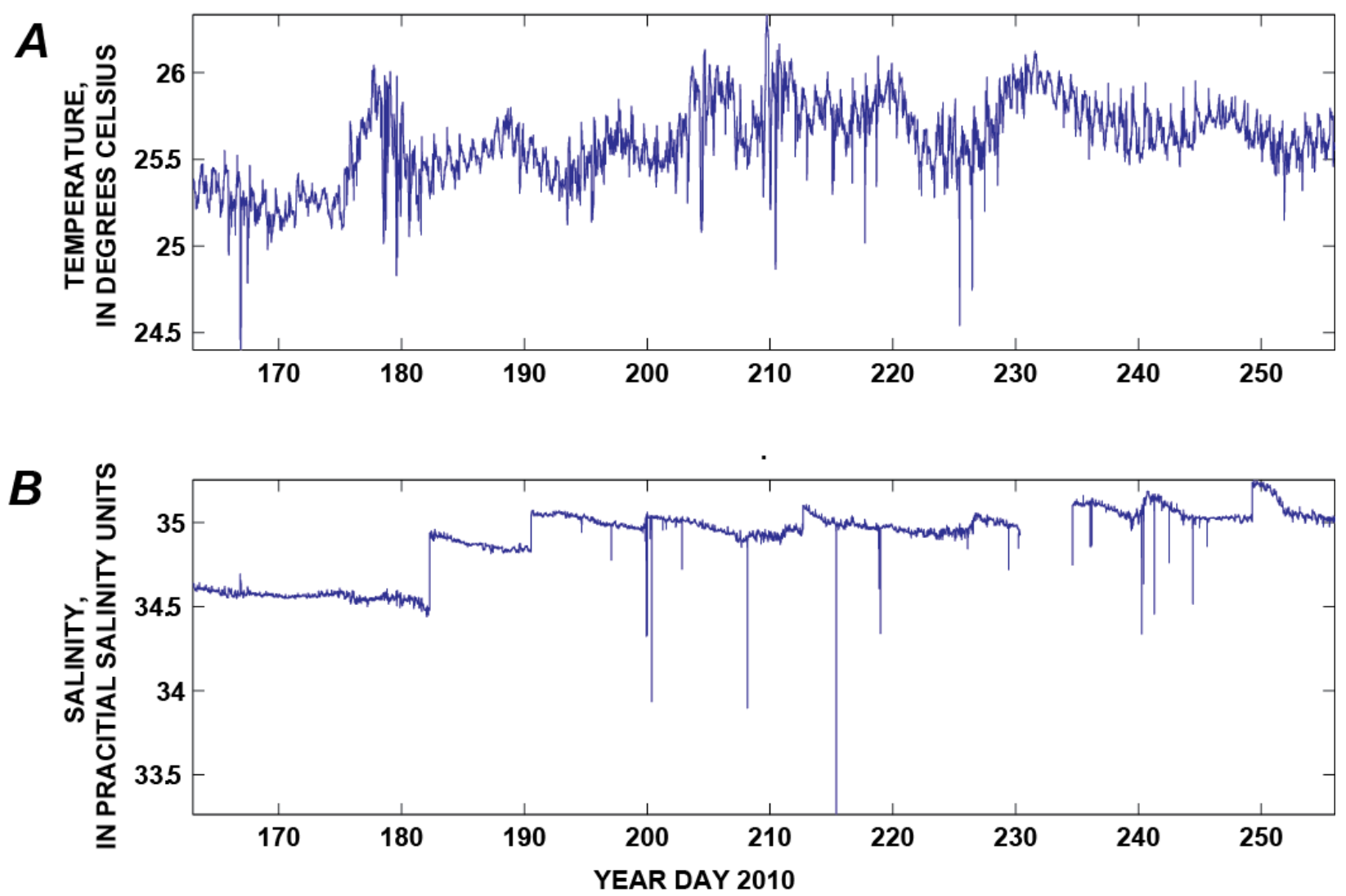
Appendix 8.3. Temperature and salinity data from the CT at the Paikō 5-m site. A, Water temperature, in degrees Celsius. B, Salinity, in Practical Salinity Units (PSU).

Paikō $5 \mathrm{~m}$

$\boldsymbol{A}$
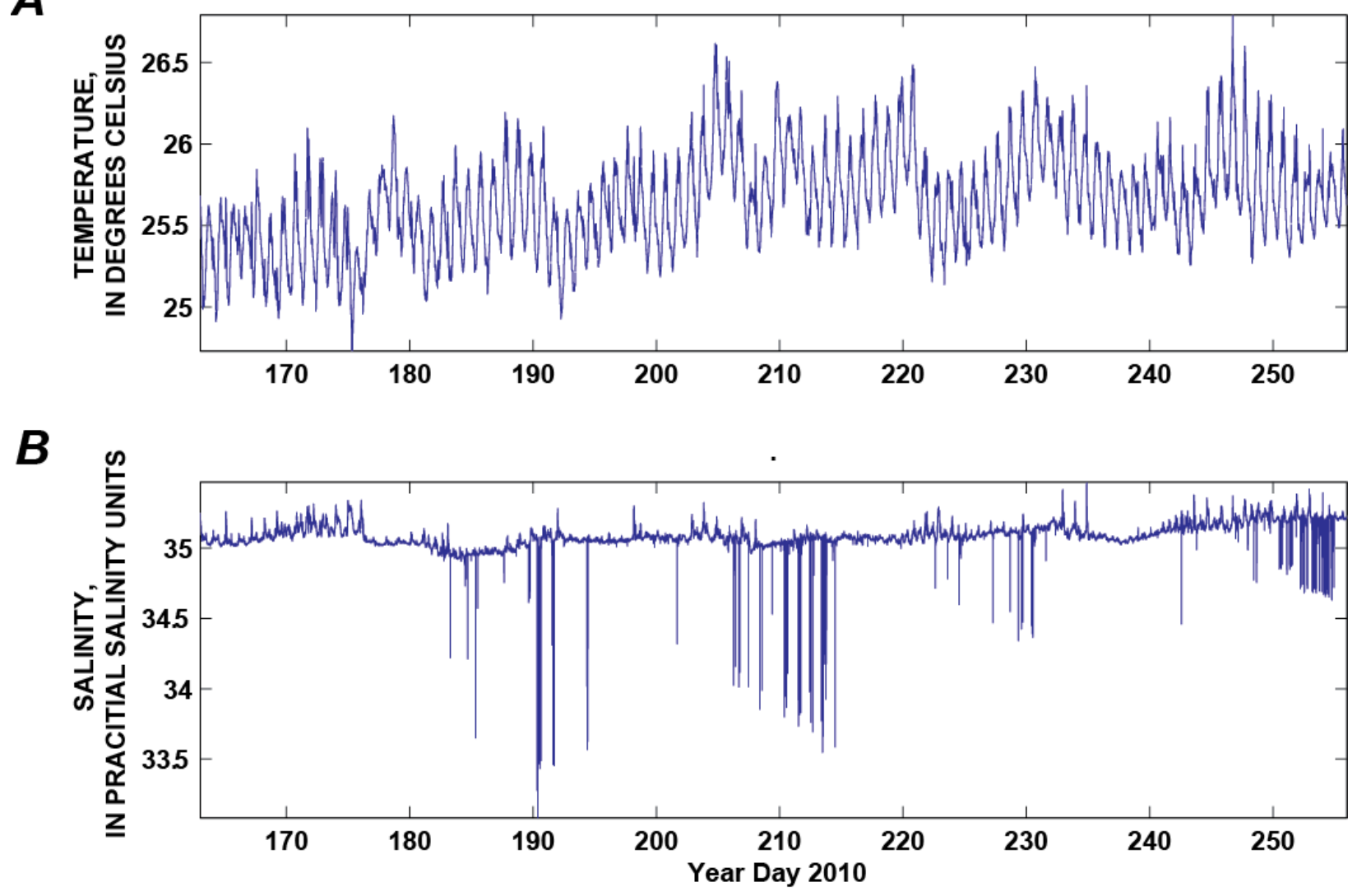
Appendix 8.4. Temperature and salinity data from the CT at the Paiko 10-m site. A, Water temperature, in degrees Celsius. B, Salinity, in Practical Salinity Units (PSU).

Paikō $10 \mathrm{~m}$
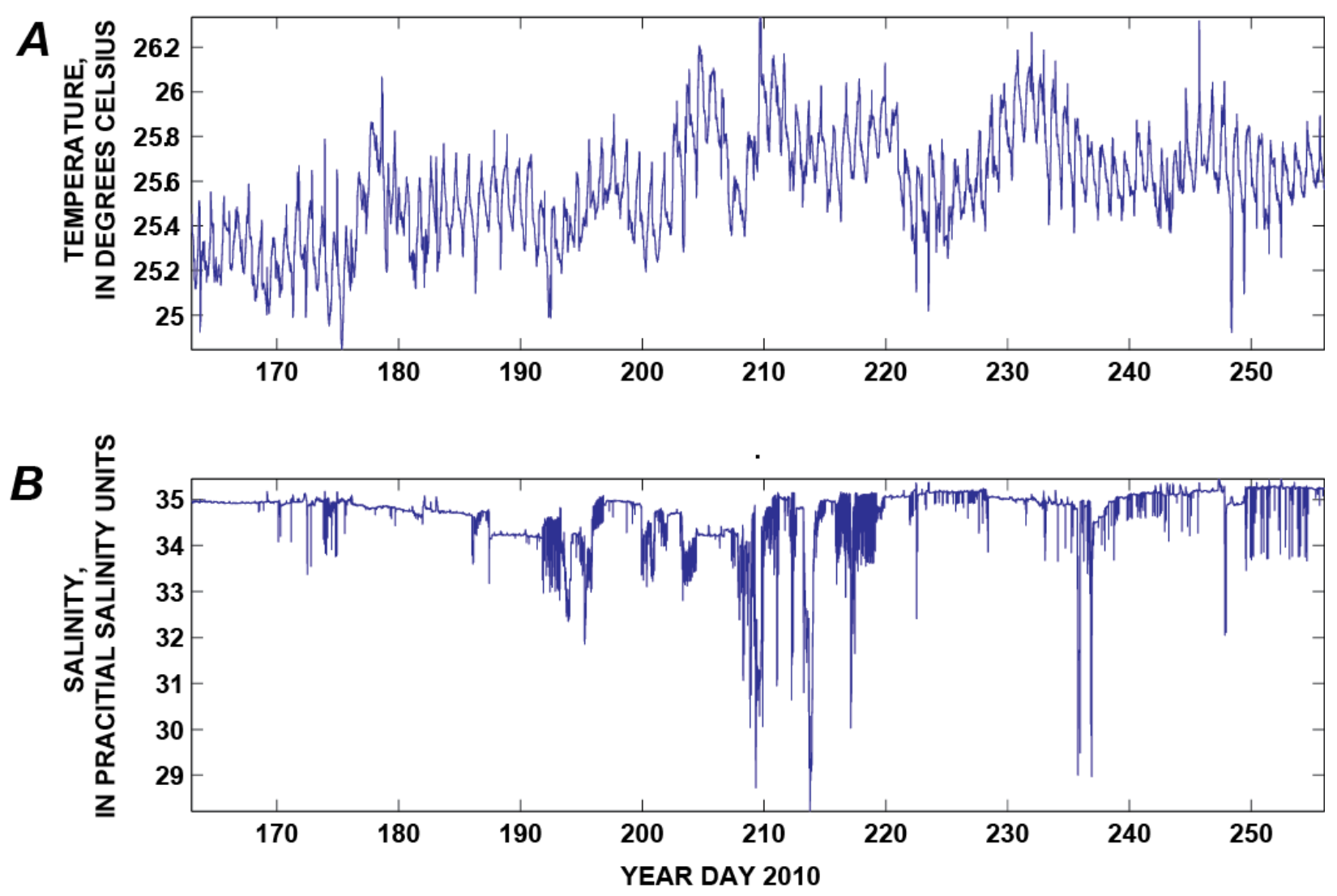
Appendix 8.5. Temperature and salinity data from the CT at the Paikō 20-m site. A, Water temperature, in degrees Celsius. B, Salinity, in Practical Salinity Units (PSU).

Paikō $20 \mathrm{~m}$

A

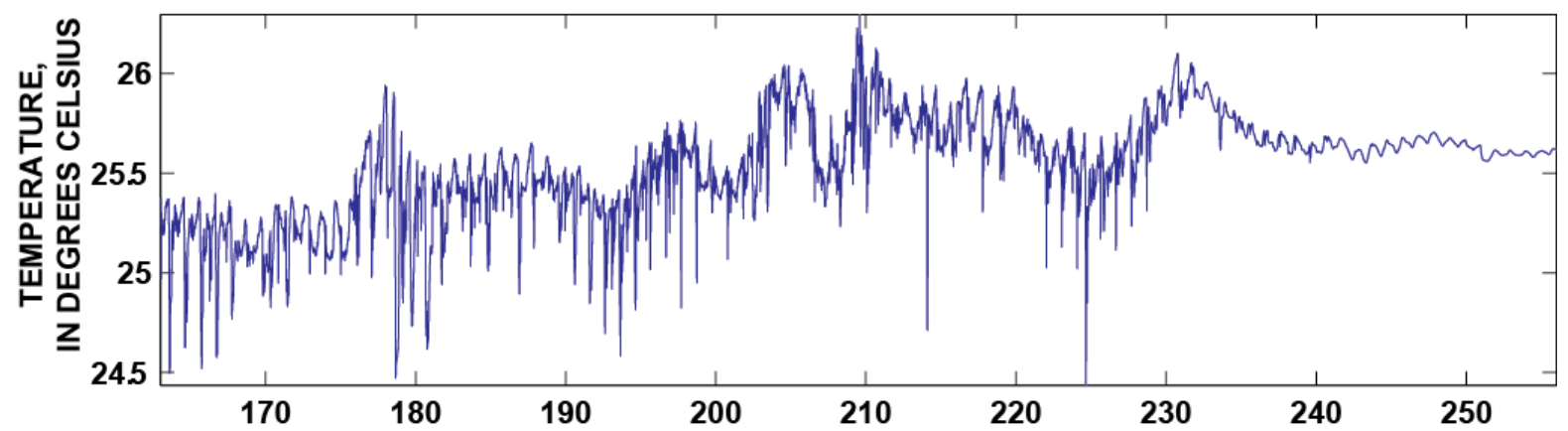

B

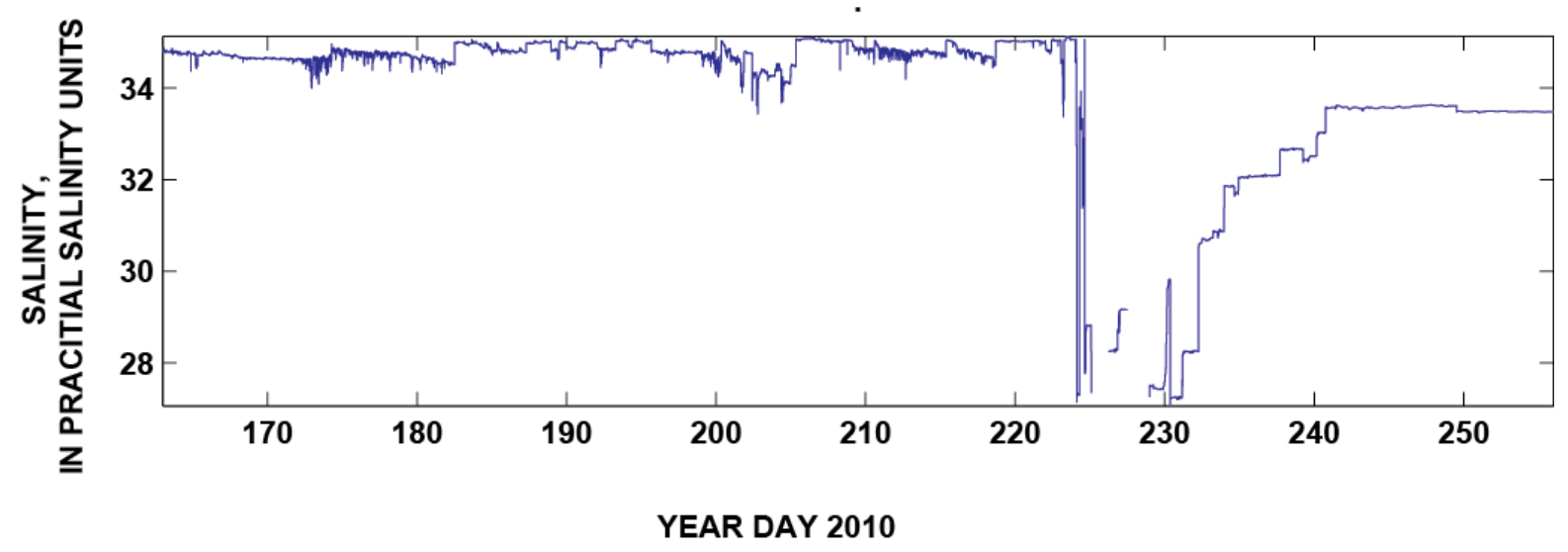


Appendix 8.6. Temperature and salinity data from the CT at the Paikō 30-m site. A, Water temperature, in degrees Celsius. B, Salinity, in Practical Salinity Units (PSU).

\section{Paikō $30 \mathrm{~m}$}
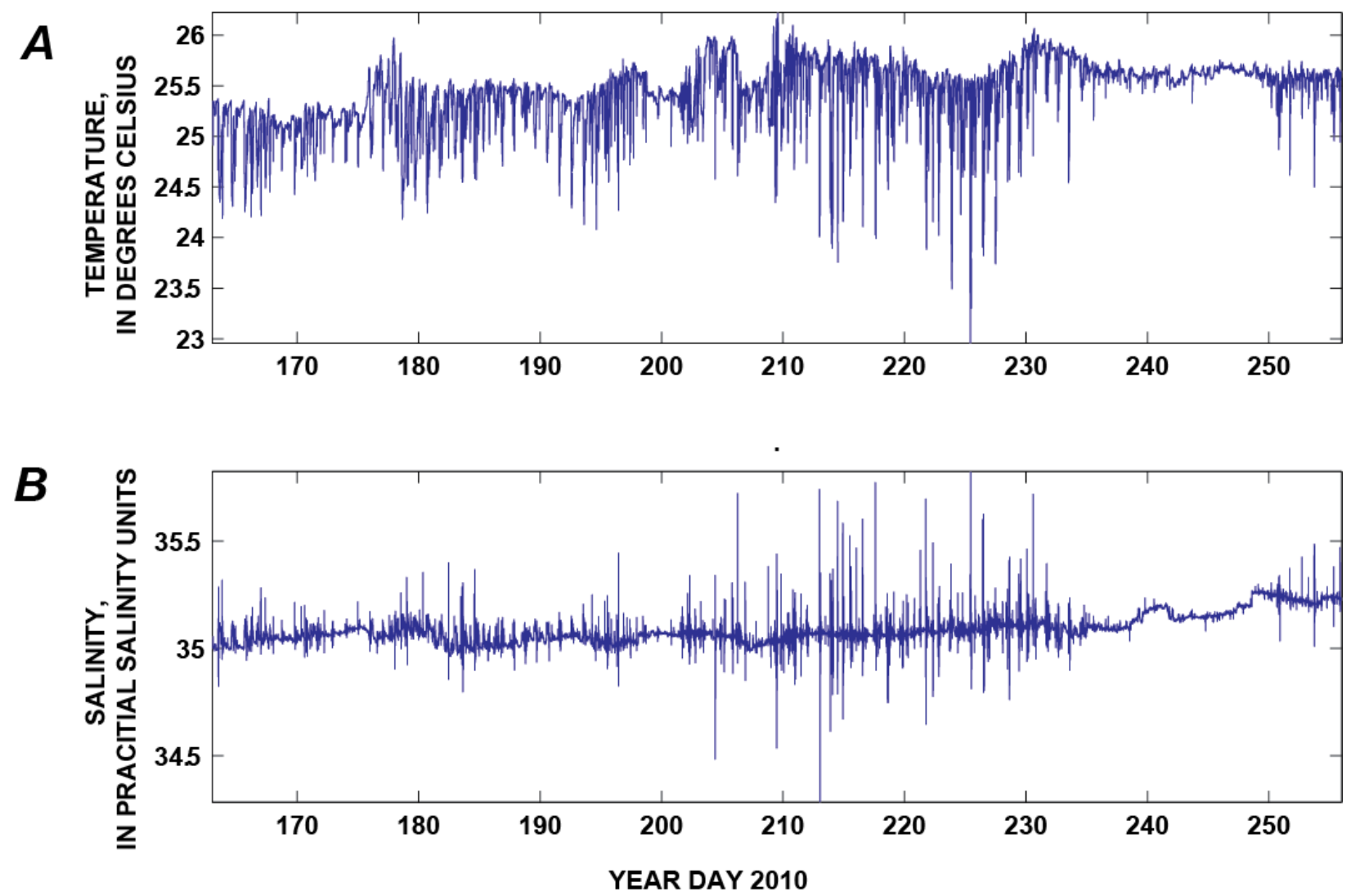


\section{Appendix 9. Maps Showing the Spatial Variability in Temperature and Salinity from Water- Column Profiler (WCP) Casts in Maunalua Bay}

Appendix 9.1. Maps showing the spatial variability in temperature, in degrees Celsius, from the WCP on 2010 Year Day 163 (June 12). A, Spatial variability of the mean temperature, in degrees Celsius, measured $1 \mathrm{~m}$ below the surface. $B$, Spatial variability of the mean temperature, in degrees Celsius, measured $1 \mathrm{~m}$ above the seabed. $C$, Spatial variability of temperature, in degrees Celsius, depth averaged for each cast, showing the mean and standard deviation.
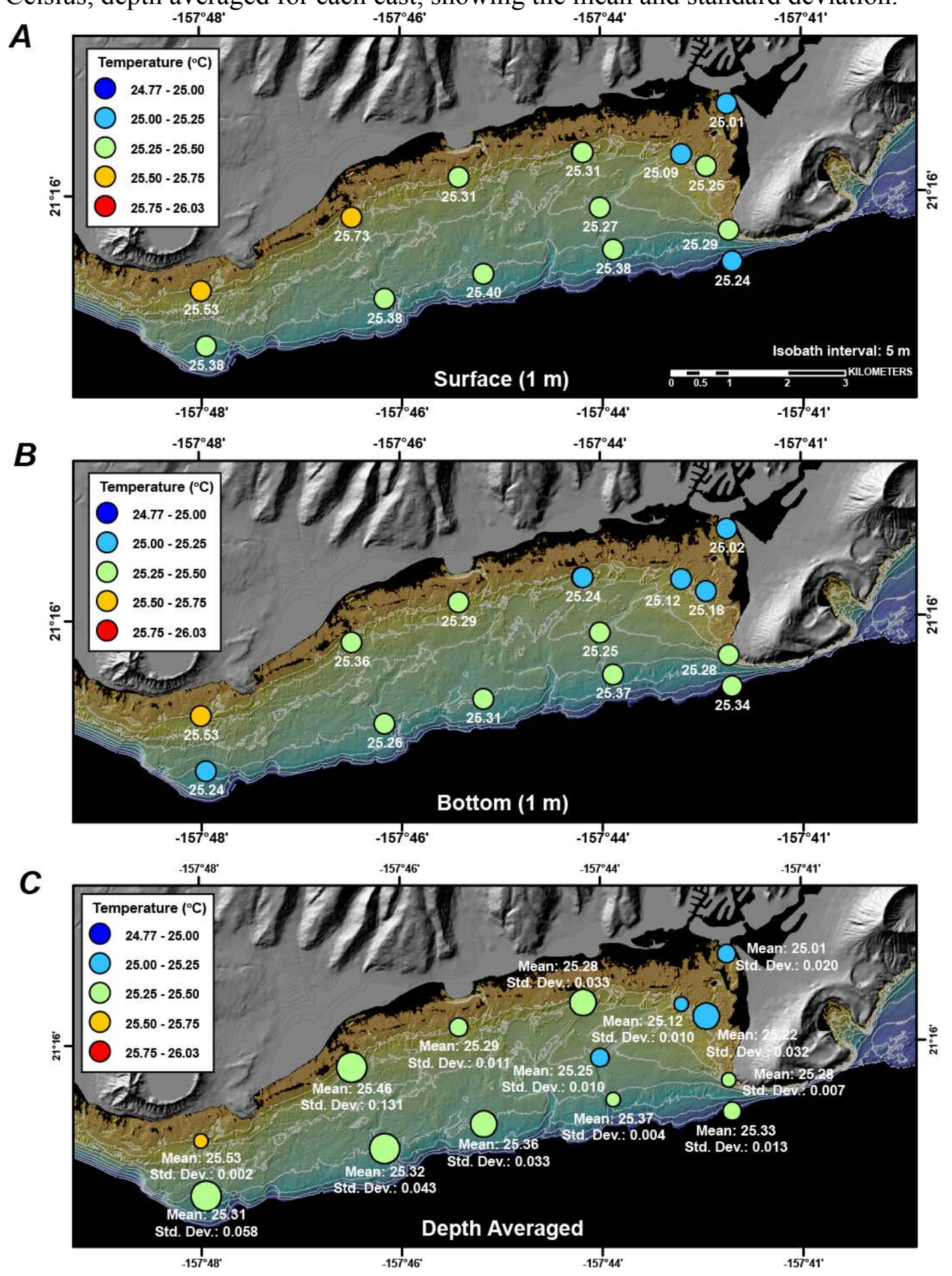
Appendix 9.2. Maps showing the spatial variability in temperature, in degrees Celsius, from the WCP on 2010 Year Day 164 (June 13). A, Mean temperature measured $1 \mathrm{~m}$ below the surface. B, Mean temperature measured $1 \mathrm{~m}$ above the seabed. $C$, Depth-averaged mean and variability in temperature.

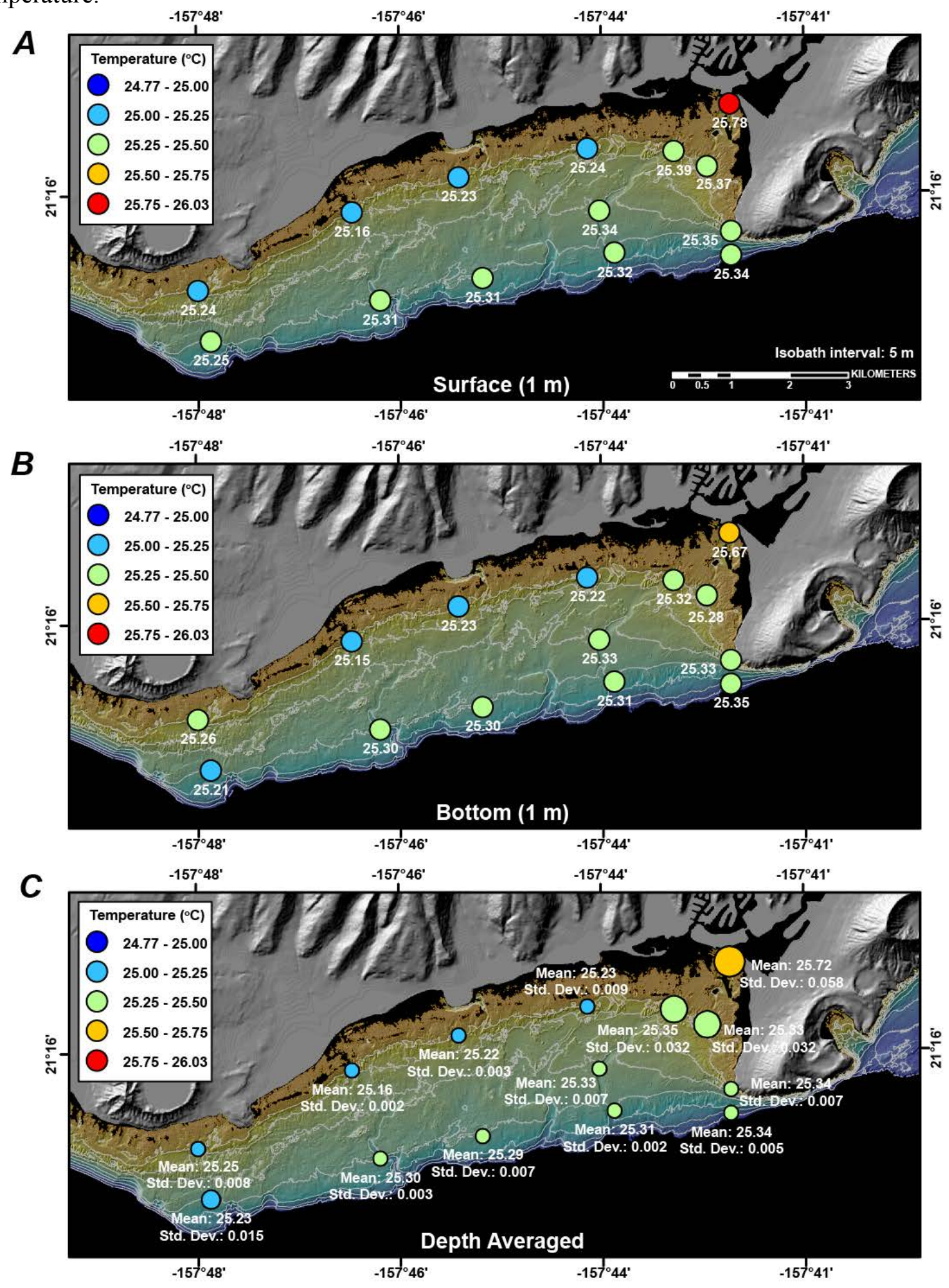


Appendix 9.3. Maps showing the spatial variability in temperature, in degrees Celsius, from the WCP on 2010 Year Day 165 (June 14). A, Mean temperature measured $1 \mathrm{~m}$ below the surface. B, Mean temperature measured $1 \mathrm{~m}$ above the seabed. $C$, Depth-averaged mean and variability in temperature.

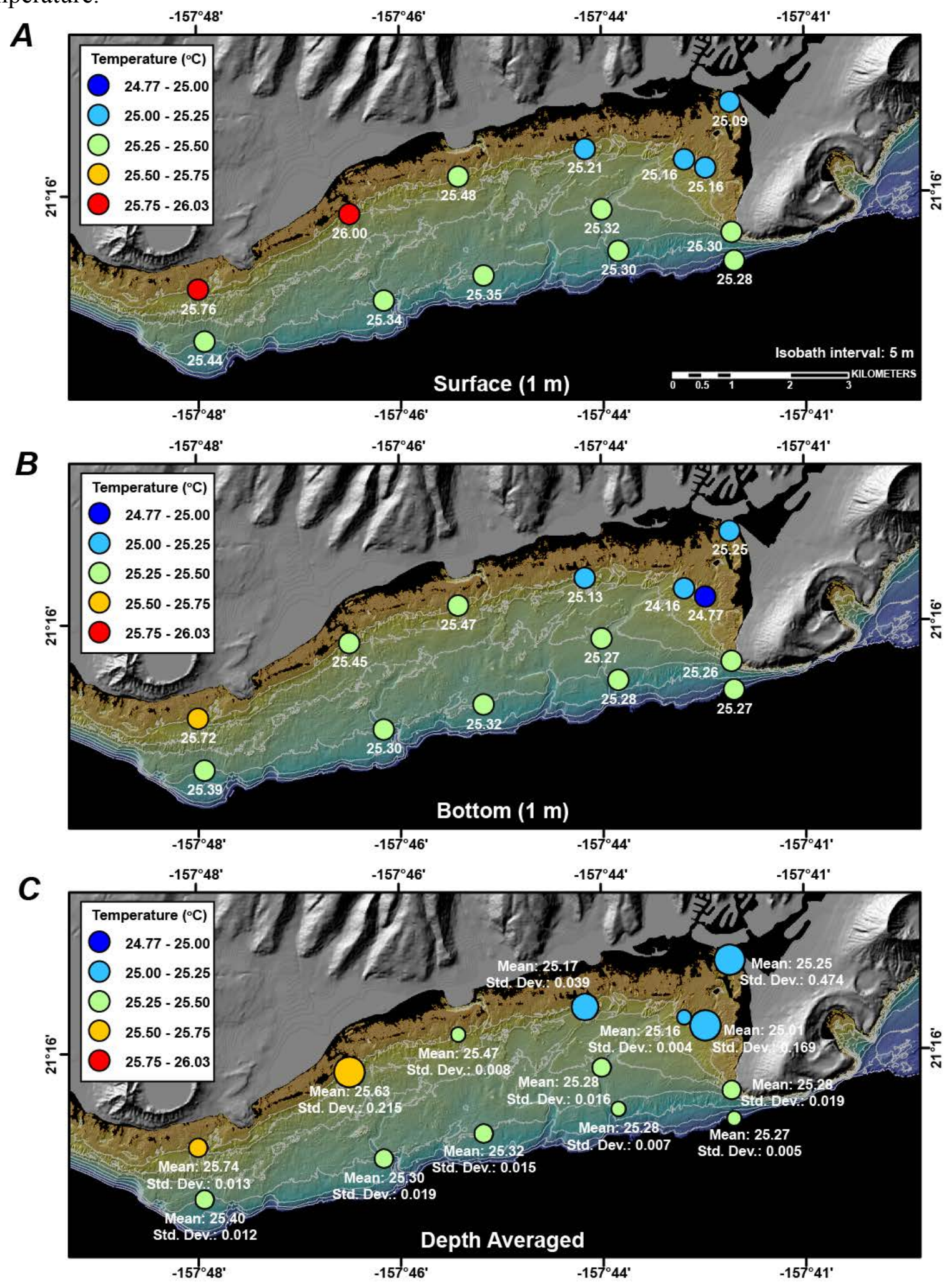


Appendix 9.4. Maps showing the spatial variability in temperature, in degrees Celsius, from the WCP on 2010 Year Day 166 (June 15). A, Mean temperature measured $1 \mathrm{~m}$ below the surface. B, Mean temperature measured $1 \mathrm{~m}$ above the seabed. $C$, Depth-averaged mean and variability in temperature.

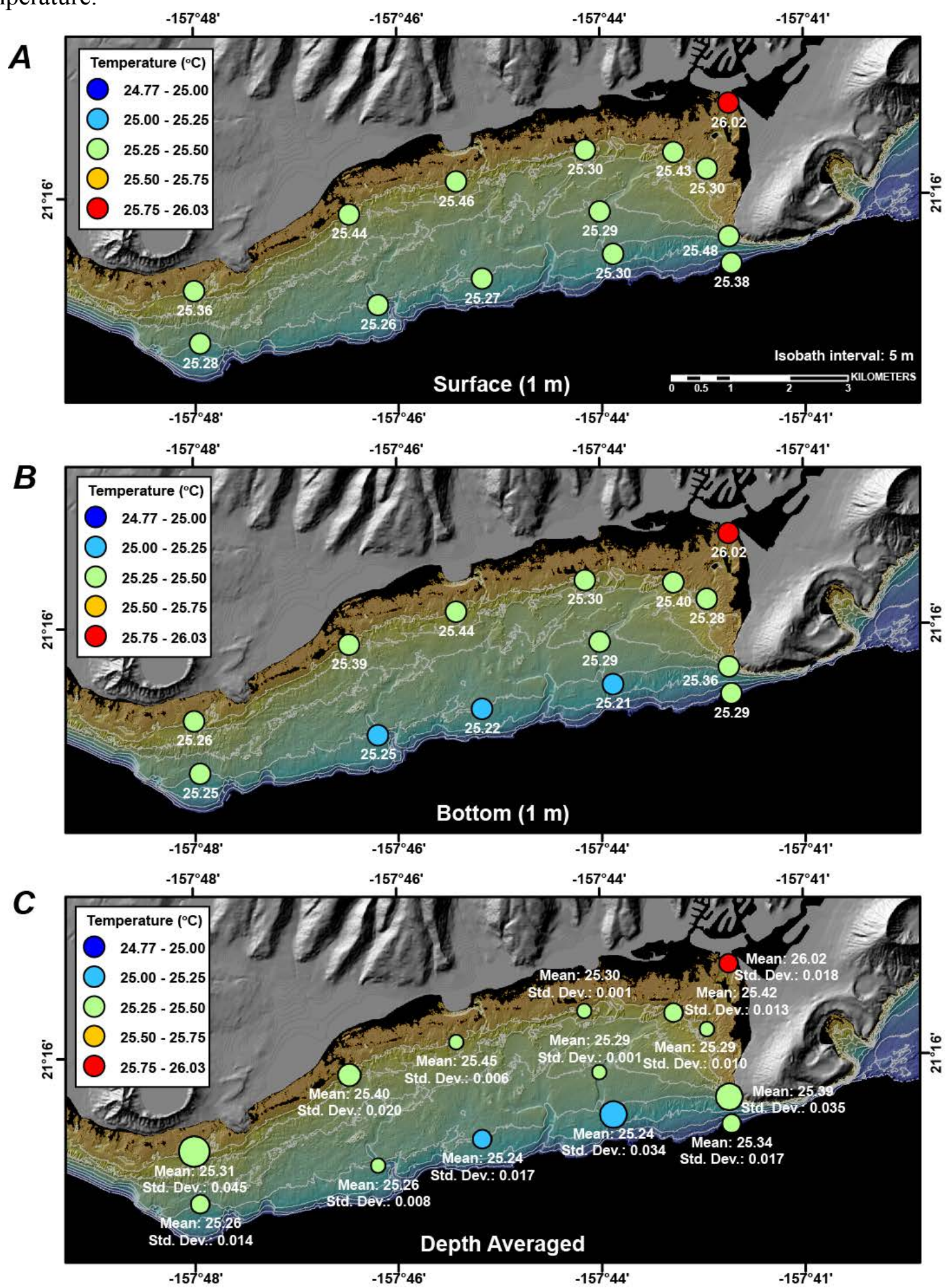


Appendix 9.5. Maps showing the spatial variability in salinity, in Pratical Salinity Units (PSU), from the WCP on 2010 Year Day 163 (June 12). A, Mean salinity measured $1 \mathrm{~m}$ below the surface. $B$, Mean salinity measured $1 \mathrm{~m}$ above the seabed. $C$, Depth-averaged mean and variability in salinity.

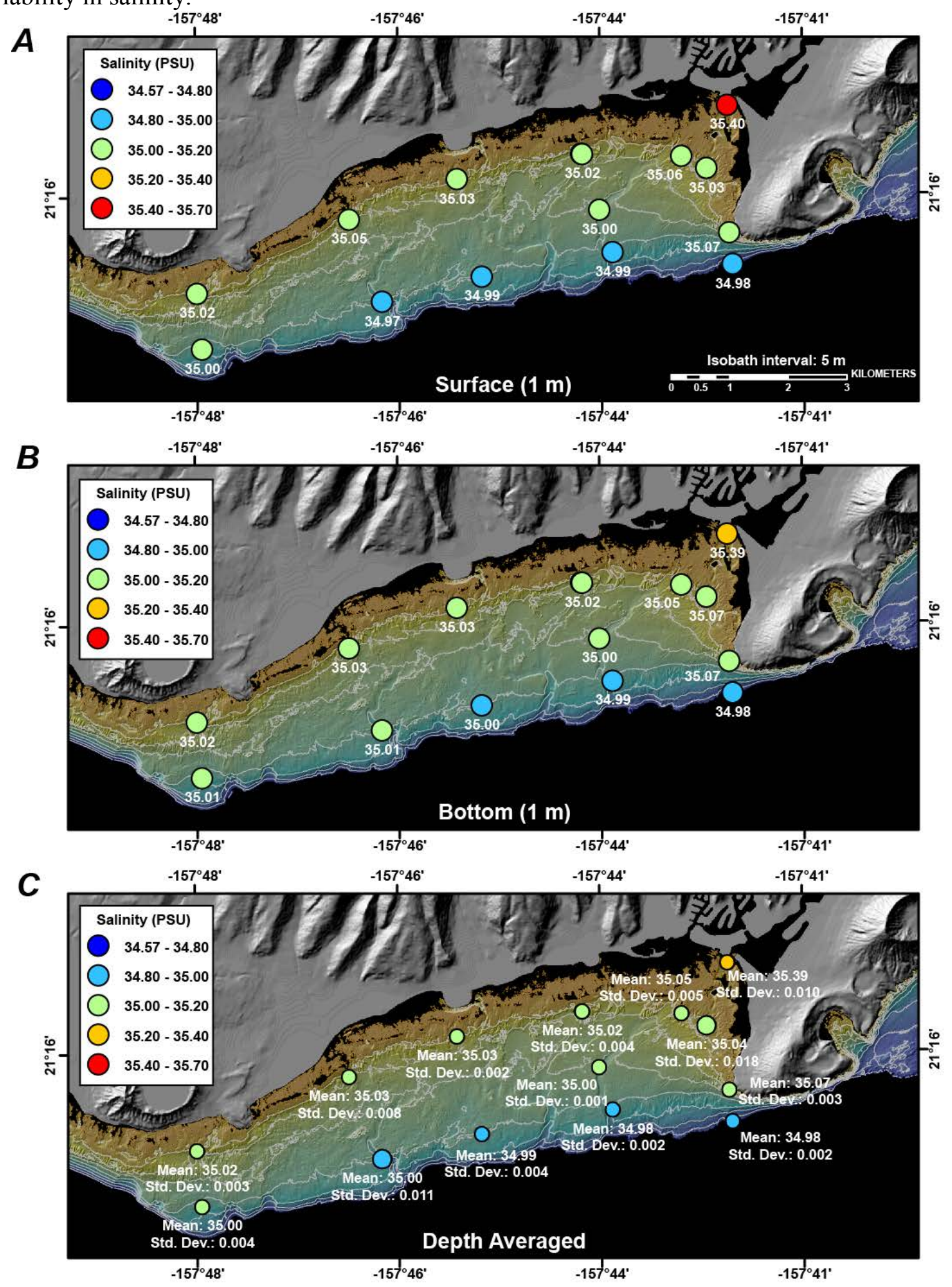


Appendix 9.6. Maps showing the spatial variability in salinity, in Pratical Salinity Units (PSU), from the WCP on 2010 Year Day 164 (June 13). A, Mean salinity measured $1 \mathrm{~m}$ below the surface. $B$, Mean salinity measured $1 \mathrm{~m}$ above the seabed. $C$, Depth-averaged mean and variability in salinity.

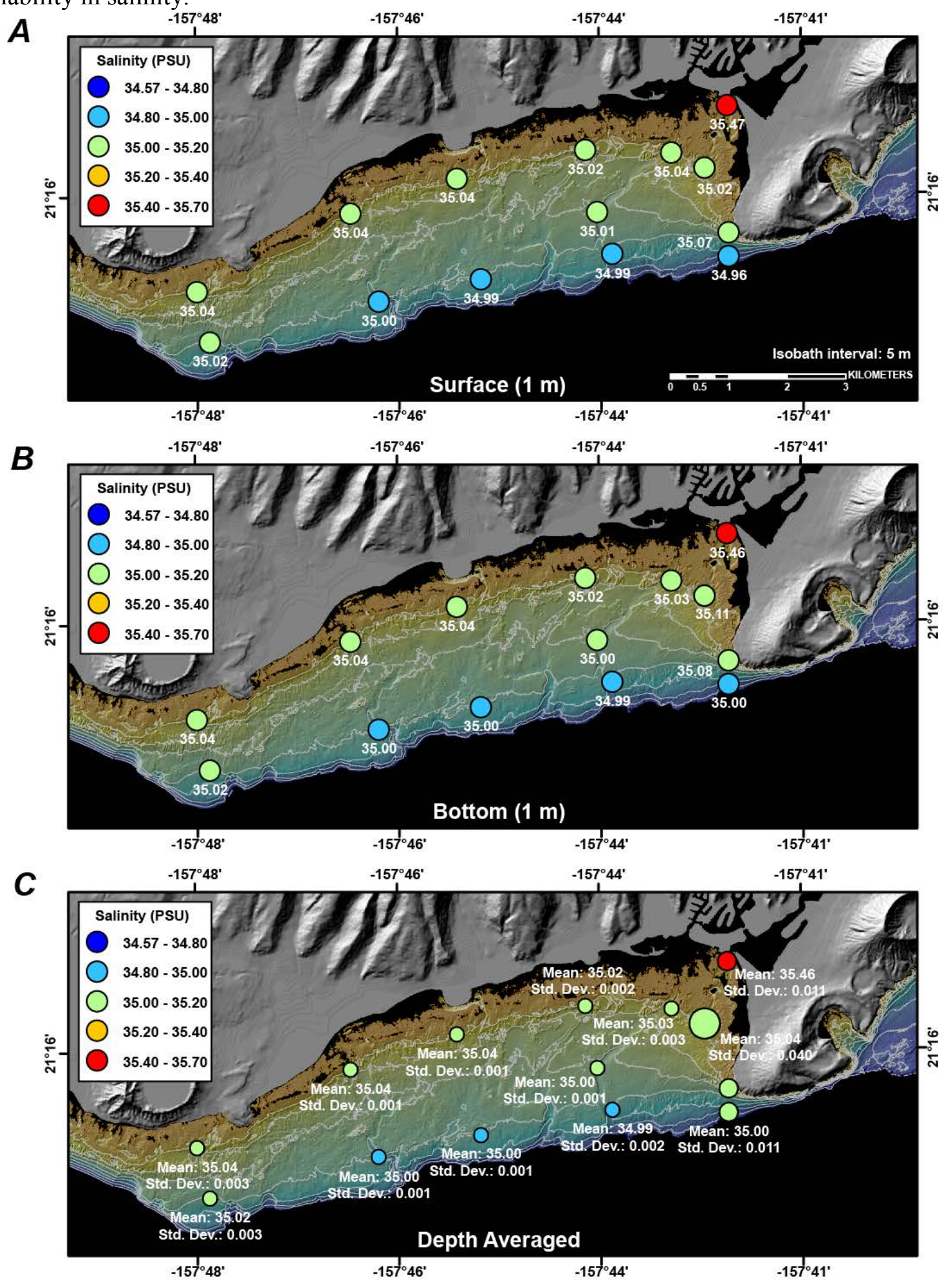


Appendix 9.7. Maps showing the spatial variability in salinity, in Pratical Salinity Units (PSU), from the WCP on 2010 Year Day 165 (June 14). A, Mean salinity measured $1 \mathrm{~m}$ below the surface. $B$, Mean salinity measured $1 \mathrm{~m}$ above the seabed. $C$, Depth-averaged mean and variability in salinity.

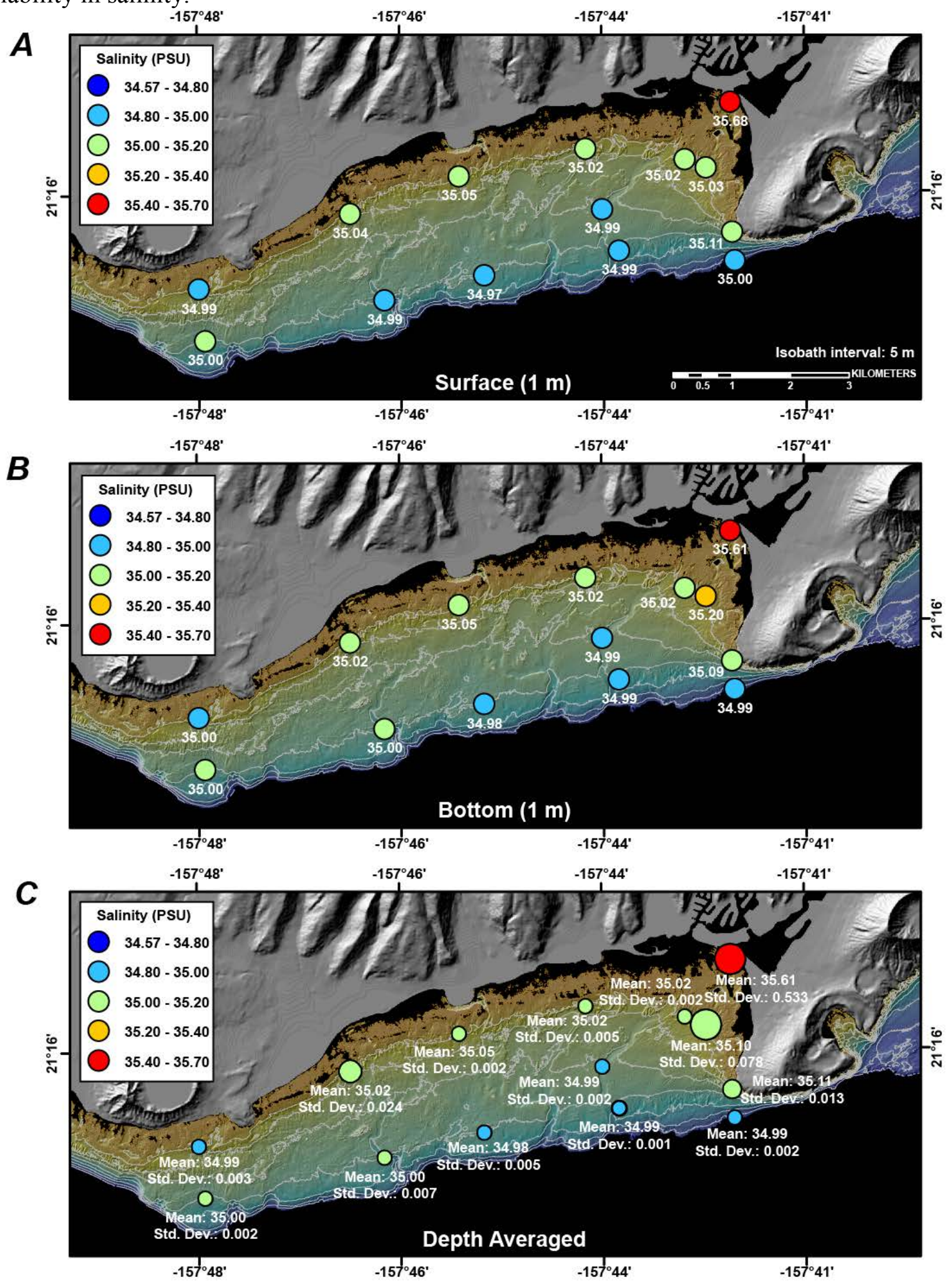


Appendix 9.8. Maps showing the spatial variability in salinity, in Pratical Salinity Units (PSU), from the WCP on 2010 Year-Day 166 (June 15). A, Mean salinity measured $1 \mathrm{~m}$ below the surface. $B$, Mean salinity measured $1 \mathrm{~m}$ above the seabed. $C$, Depth-averaged mean and variability in salinity.

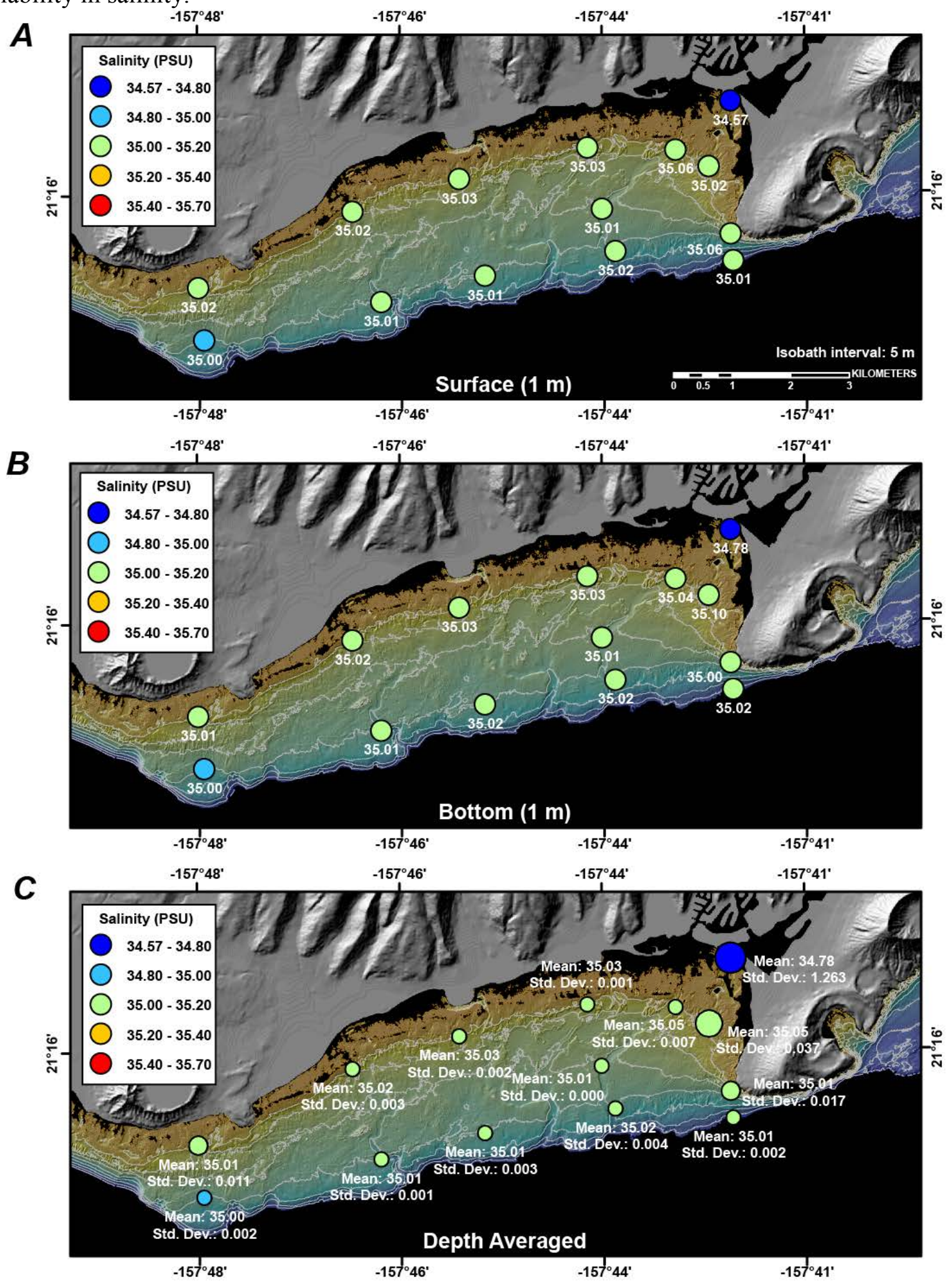


Appendix 10. Maps Showing the Spatial Variability in Near-Surface Current Speeds and Directions from Vessel-Mounted Acoustic Doppler Current Profiler (VM-ADCP) Surveys in Maunalua Bay

Appendix 10.1. Maps showing the spatial variability in near-surface current speed and direction, in meters per second from true north, from the VM-ADCP surveys. Mean and variability of current speed measured $2 \mathrm{~m}$ below the surface on 2010 Year Day 163 (June 12).

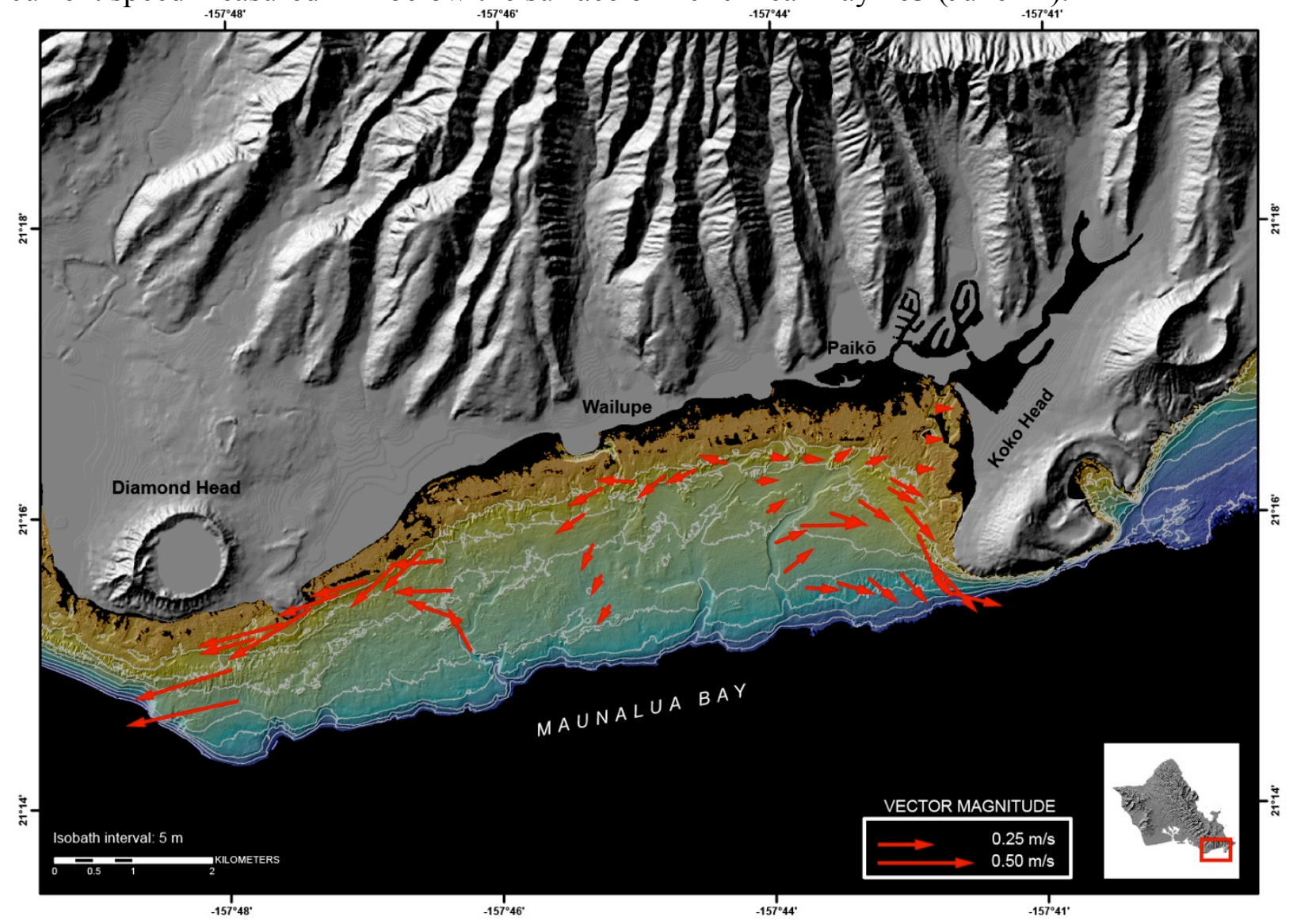


Appendix 10.2. Maps showing the spatial variability in near-surface current speed and direction, in meters per second from true north, from the VM-ADCP surveys. Mean and variability of current speed measured $2 \mathrm{~m}$ below the surface on 2010 Year Day 164 (June 13).

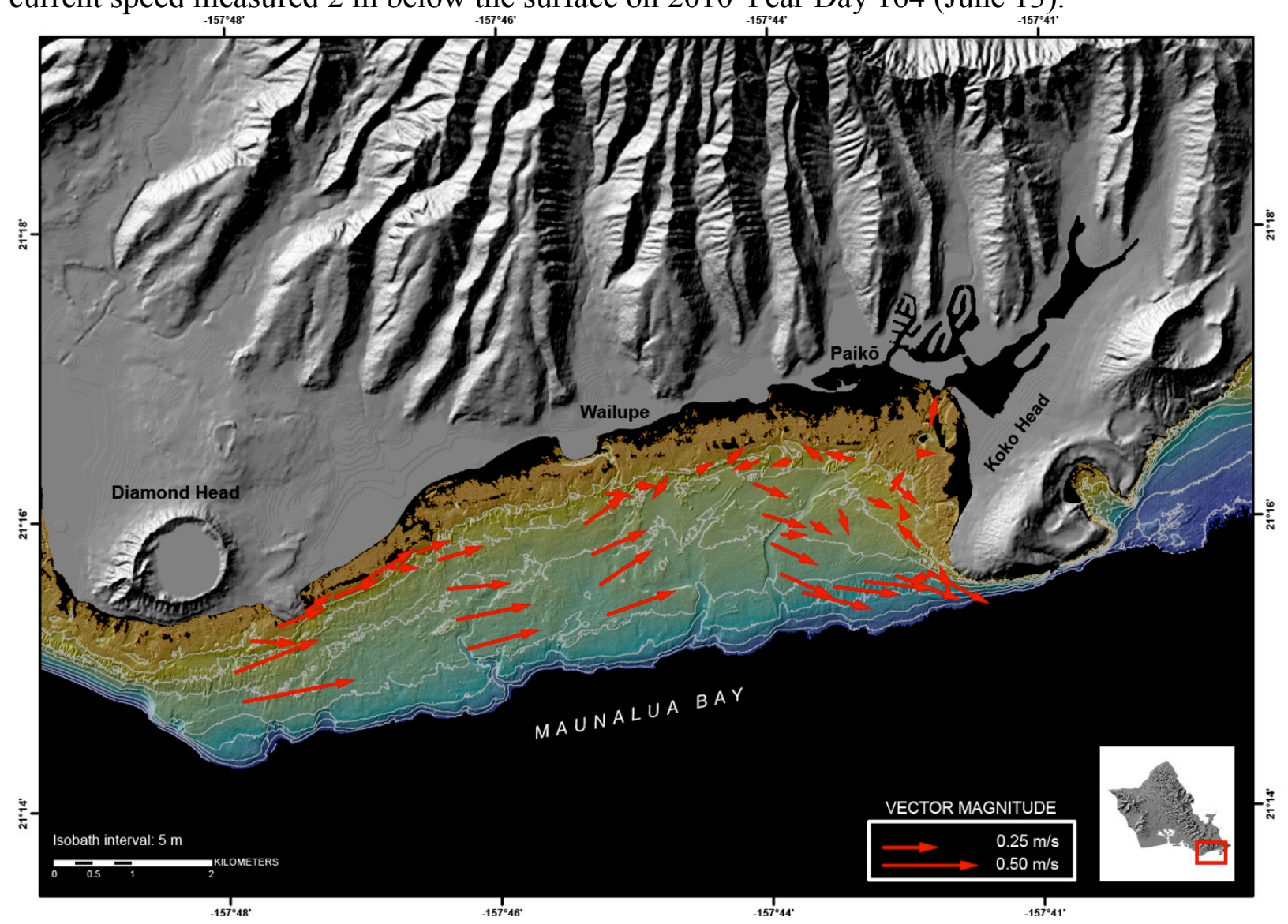


Appendix 10.3. Maps showing the spatial variability in near-surface current speed and direction, in meters per second from true north, from the VM-ADCP surveys . Mean and variability of current speed measured $2 \mathrm{~m}$ below the surface on 2010 Year Day 165 (June 14).

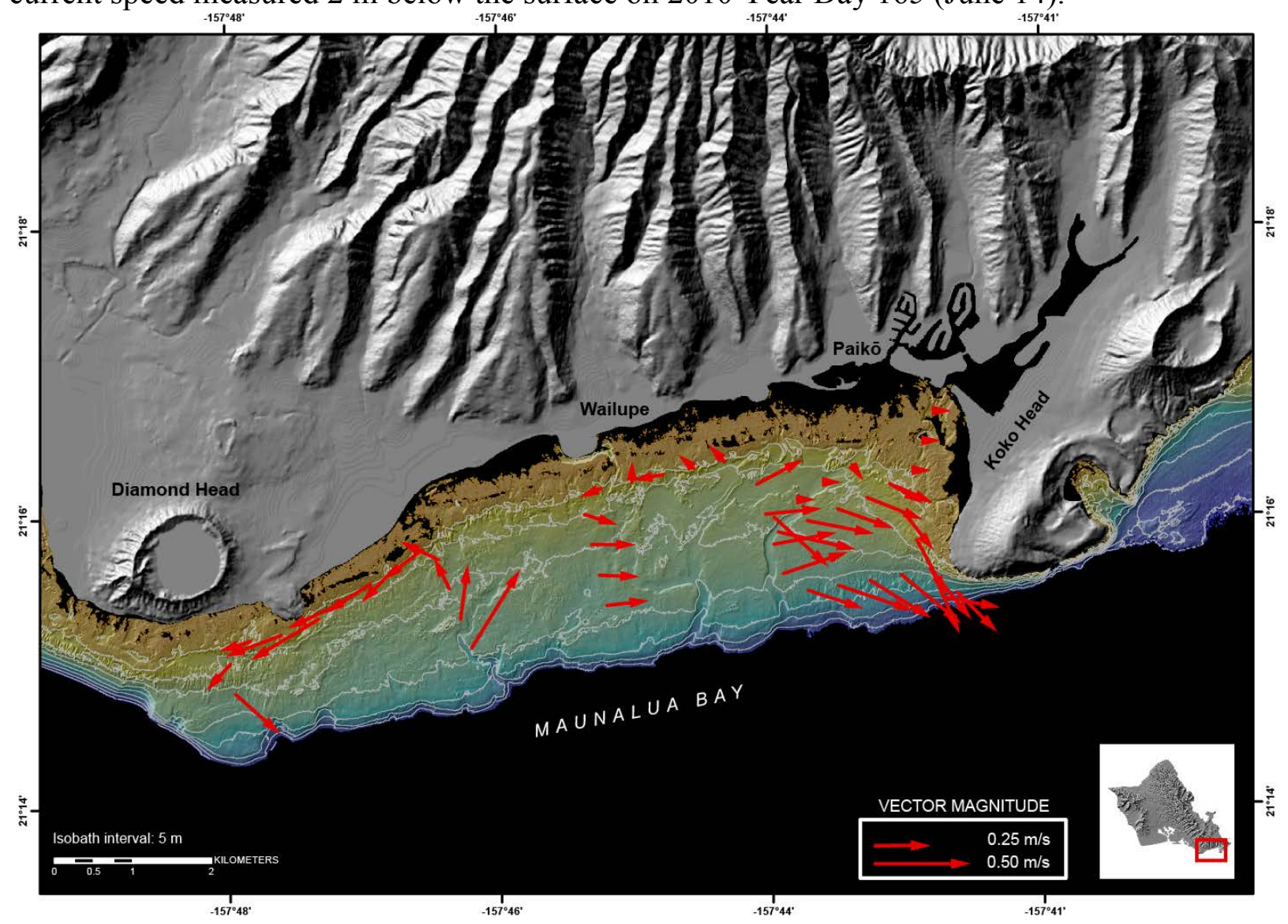


Appendix 10.4. Maps showing the spatial variability in near-surface current speed and direction, in meters per second from true north, from the VM-ADCP surveys .Mean and variability of current speed measured $2 \mathrm{~m}$ below the surface for on 2010 Year Day 166 (June 15).

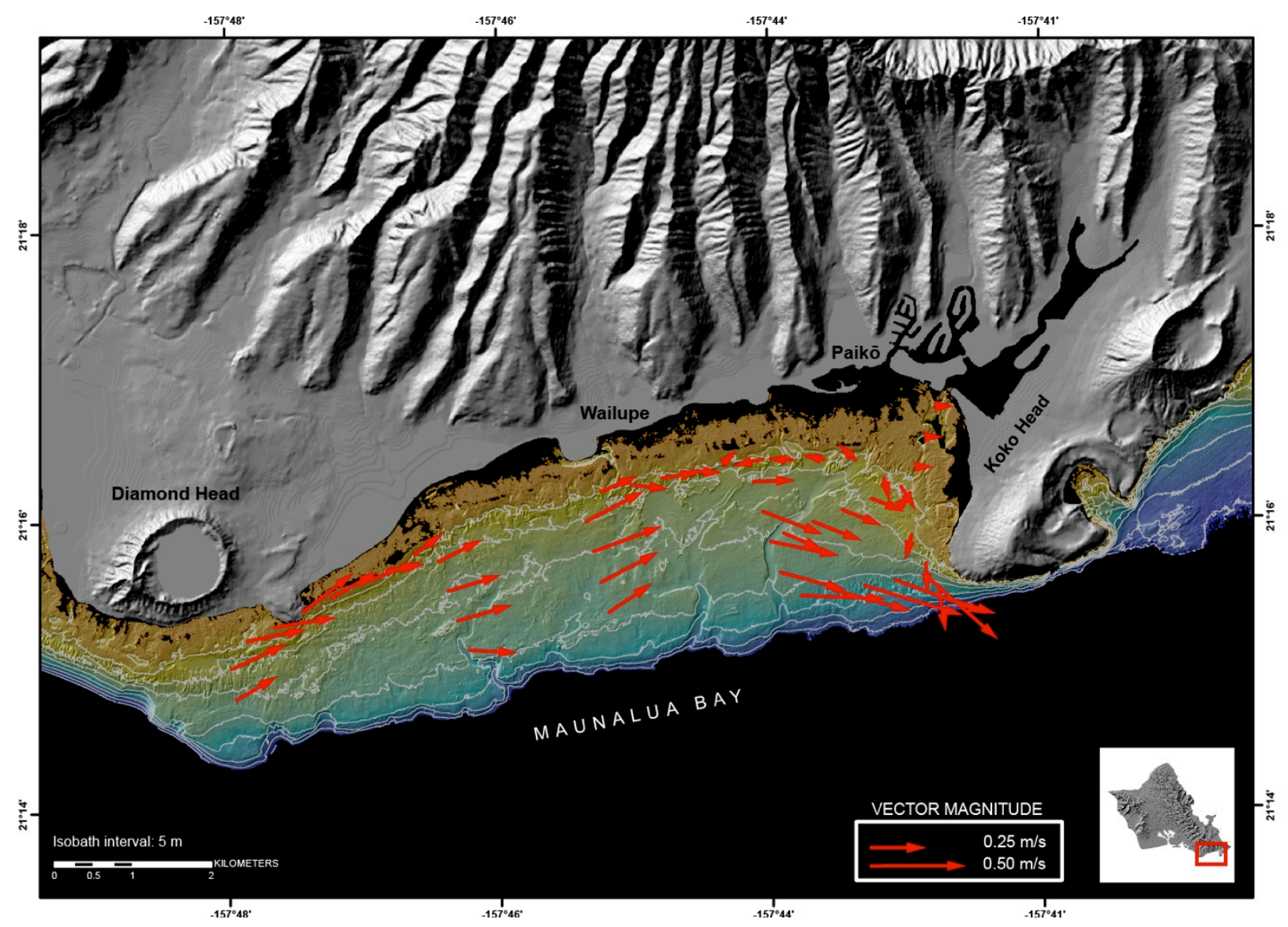




\section{Appendix 11. Maps and Time-Series Plots of Lagrangian Surface-Drifter Deployments in Maunalua Bay}

Appendix 11.1. Map of Lagrangian surface-drifter movement and time-series plot of data for a drifter released at location A on 2010 Year Day 163 (June 12) at 22:50 HST and recovered on 2010 Year Day 164 (June 13) at 13:18 HST. A, Map of drifter hourly locations and velocities, in meters per second, through time. $B$, Stick plot of drifter velocity and direction, in meters per second from true north, during the deployment. Dashed line represents drifter speeds. $C$, Stick plot of wind velocity (black), in meters per second from true north, and tidal height (blue), in meters, during the drifter deployment. Dashed line represents wind speed.
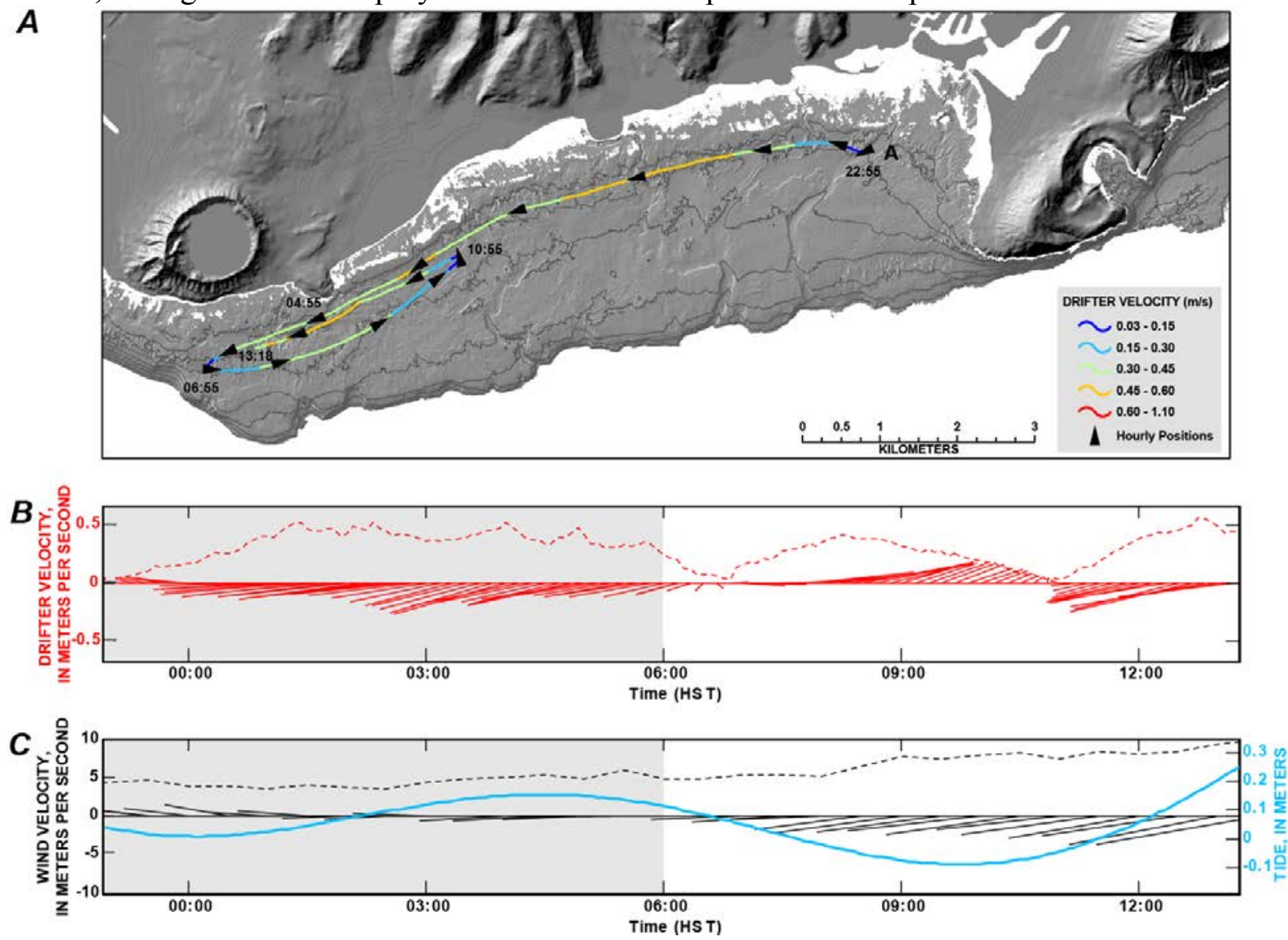
Appendix 11.2. Map of Lagrangian surface-drifter movement and time-series plot of data for a drifter released at location C on 2010 Year Day 163 (June 12) at 23:30 HST and recovered on 2010 Year Day 164 (June 13) at 07:54 HST. A, Map of drifter hourly locations and velocities, in meters per second, through time. $B$, Stick plot of drifter velocity and direction, in meters per second from true north, during the deployment. Dashed line represents drifter speeds. $C$, Stick plot of wind velocity (black), in meters per second from true north, and tidal height (blue), in meters, during the drifter deployment. Dashed line represents wind speed.
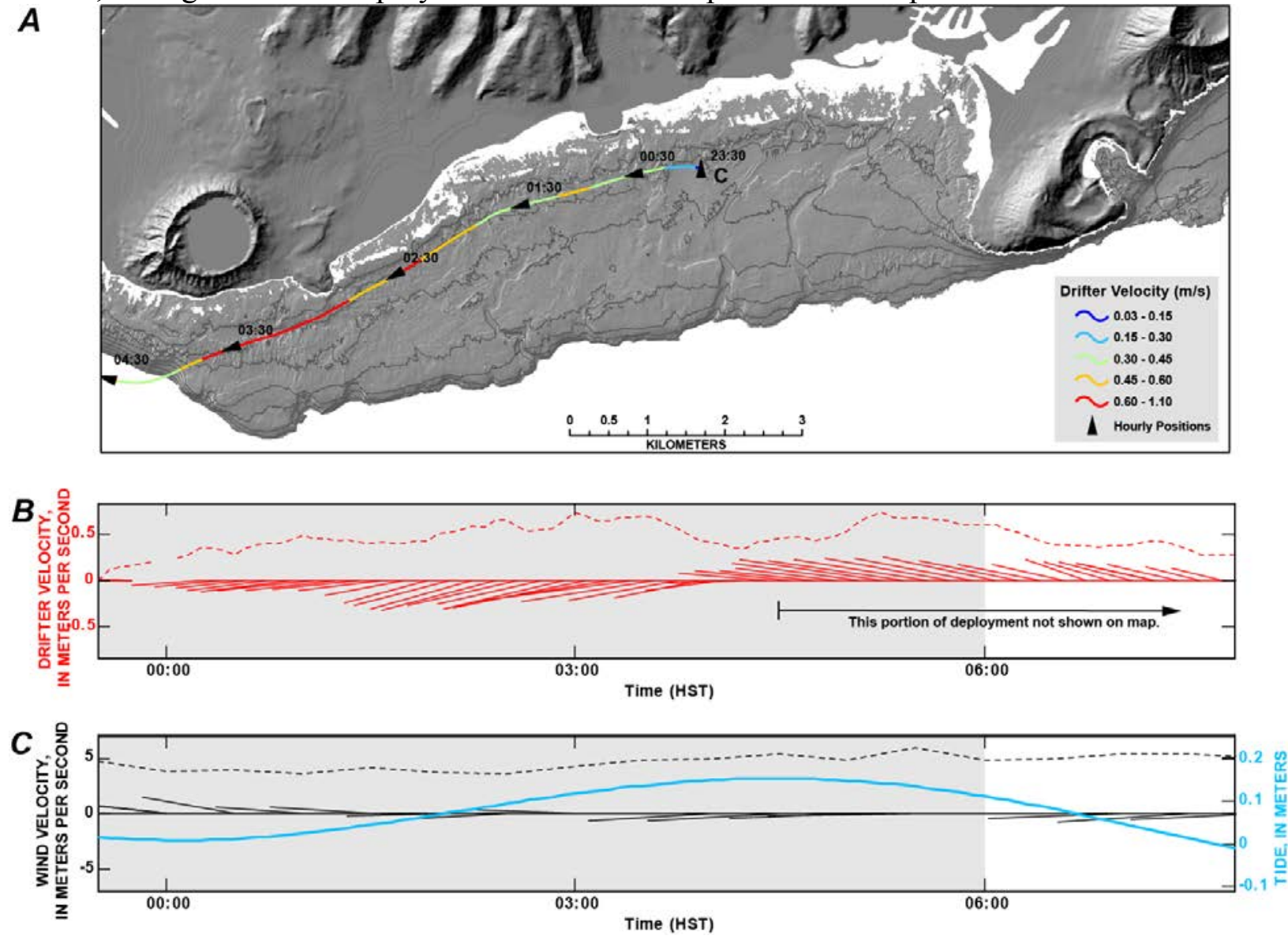
Appendix 11.3. Map of Lagrangian surface-drifter movement and time-series plot of data for a drifter released at location A on 2010 Year Day 164 (June 13) at 23:18 HST and recovered on 2010 Year Day 165 (June 14) at 13:40 HST. A, Map of drifter hourly locations and velocities, in meters per second, through time. $B$, Stick plot of drifter velocity and direction, in meters per second from true north, during the deployment. Dashed line represents drifter speeds. $C$, Stick plot of wind velocity (black), in meters per second from true north, and tidal height (blue), in meters, during the drifter deployment. Dashed line represents wind speed.
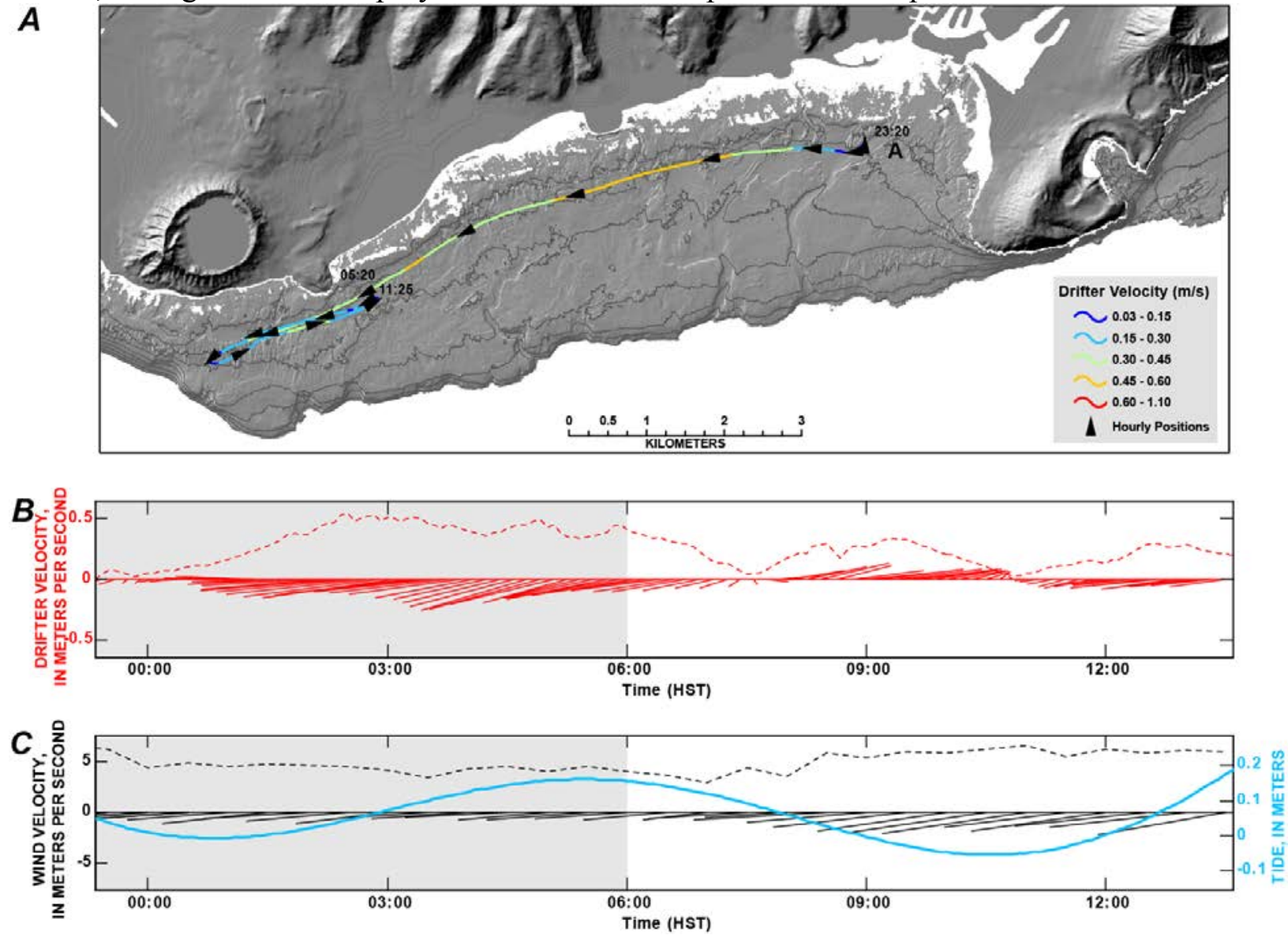
Appendix 11.4. Map of Lagrangian surface-drifter movement and time-series plot of data for a drifter released at location A on 2010 Year Day 164 (June 13) at 23:33 HST and recovered on 2010 Year Day 165 (June 14) at 19:57 HST. A, Map of drifter hourly locations and velocities, in meters per second, through time. $B$, Stick plot of drifter velocity and direction, in meters per second from true north, during the deployment. Dashed line represents drifter speeds. $C$, Stick plot of wind velocity (black), in meters per second from true north, and tidal height (blue), in meters, during the drifter deployment. Dashed line represents wind speed.
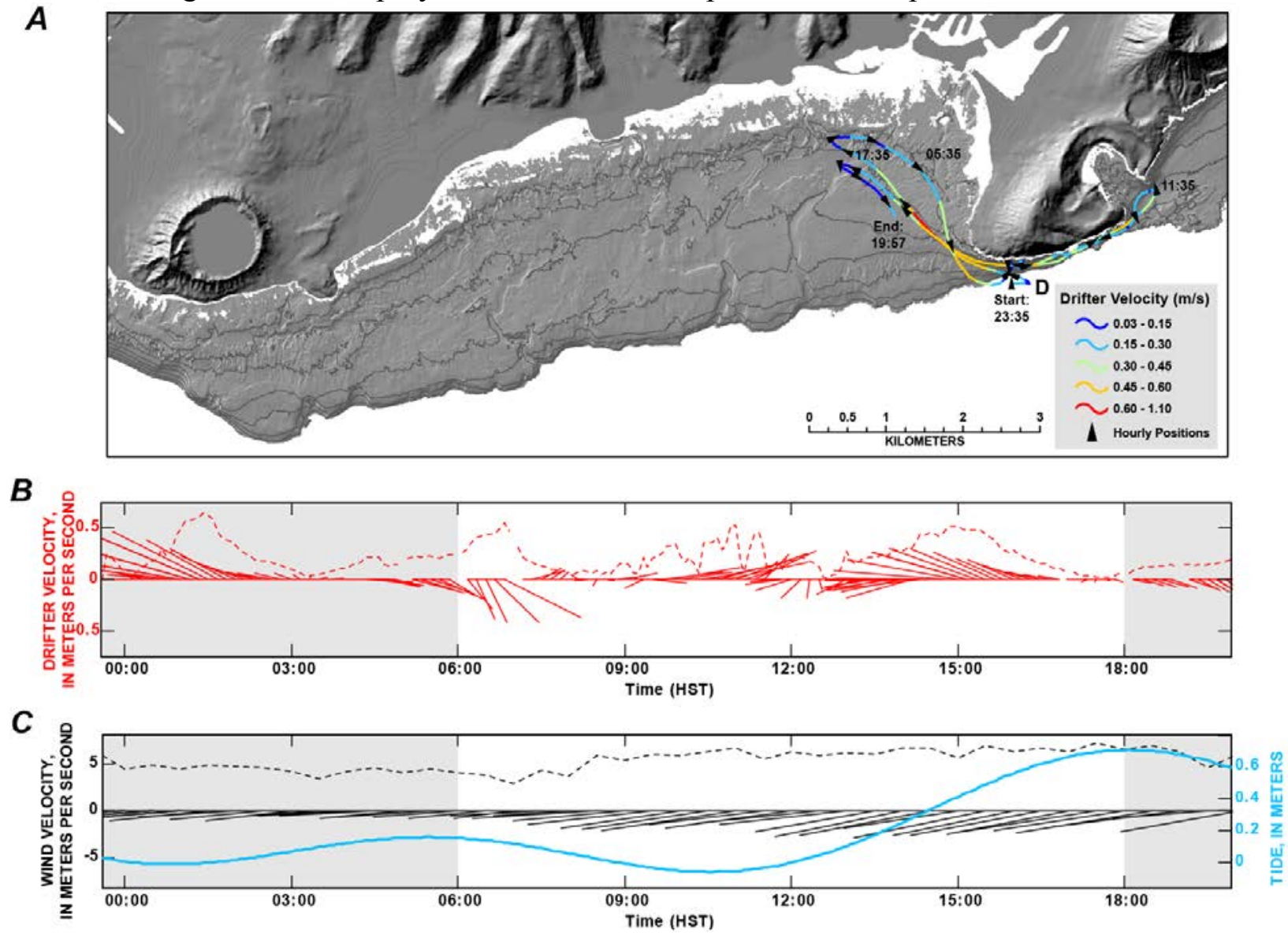
Appendix 11.5. Map of Lagrangian surface drifter movement and time-series plot of data for a drifter released at location A on 2010 Year Day 165 (June 14) at 23:11 HST and recovered on 2010 Year Day 166 (June 15) at 10:20 HST. A, Map of drifter hourly locations and velocities, in meters per second, through time. $B$, Stick plot of drifter velocity and direction, in meters per second from true north, during the deployment. Dashed line represents drifter speeds. $C$, Stick plot of wind velocity (black), in meters per second from true north, and tidal height (blue), in meters, during the drifter deployment. Dashed line represents wind speed.

$\boldsymbol{A}$

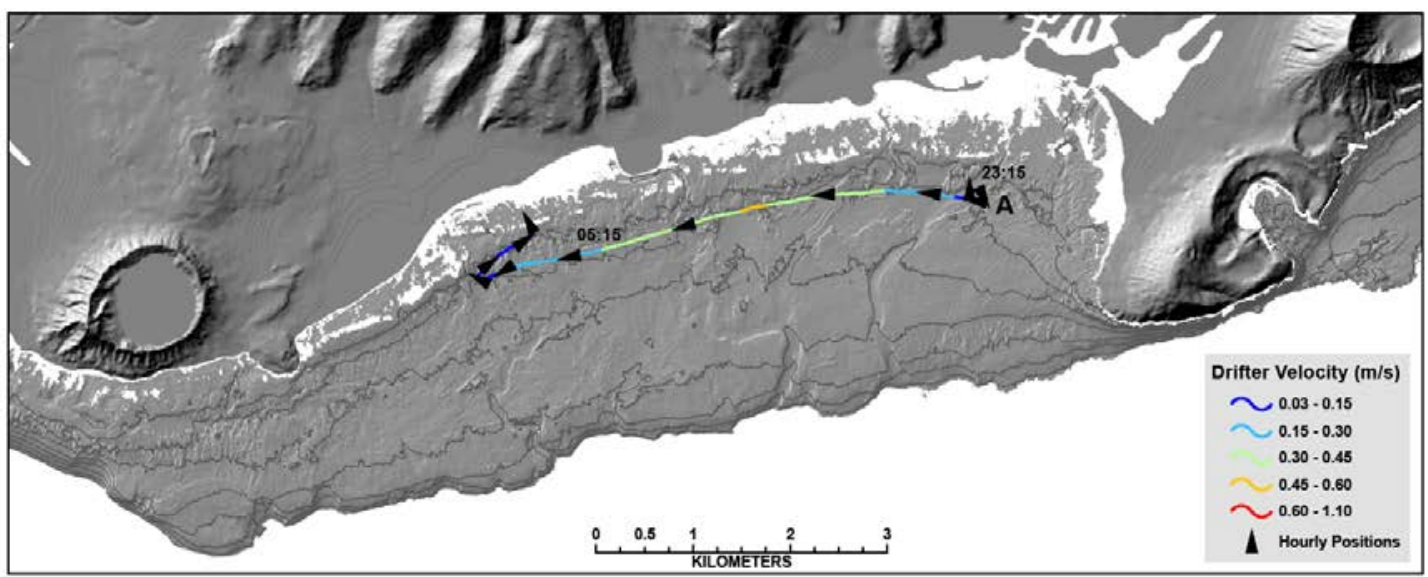

B
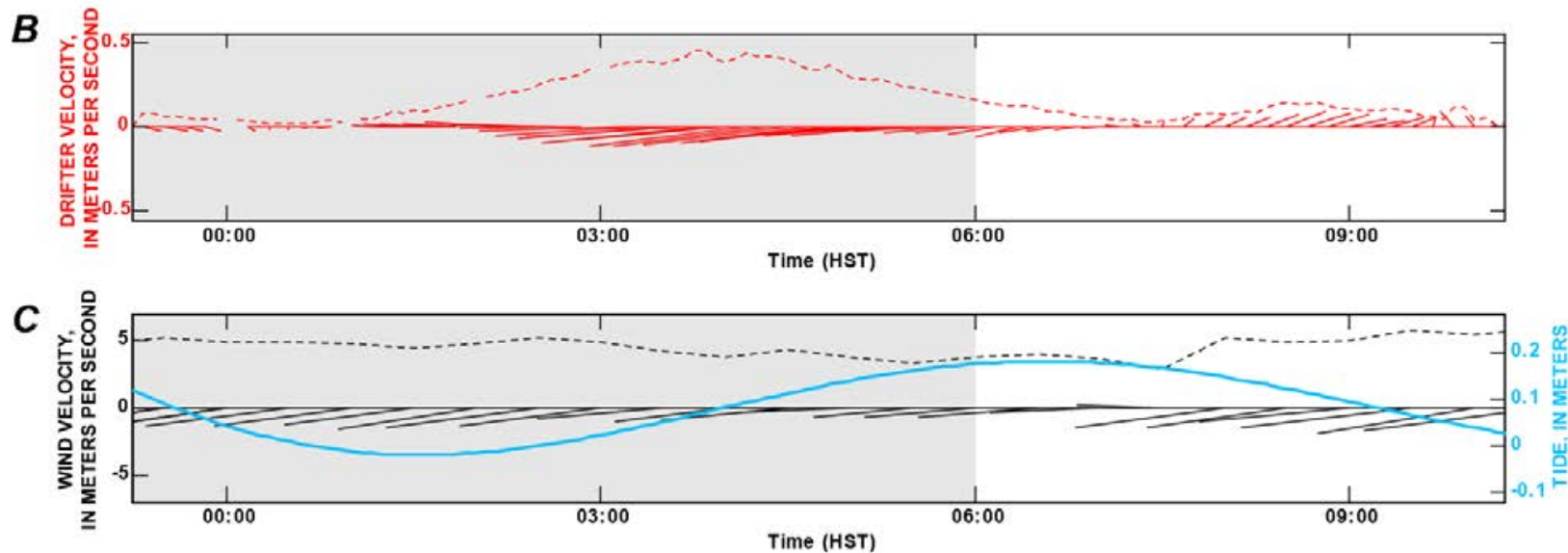
Appendix 11.6. Map of Lagrangian surface drifter movement and time-series plot of data for a drifter released at location A on 2010 Year Day 165 (June 14) at 23:38 HST and recovered on 2010 Year Day 166 (June 15) at 08:29 HST. A, Map of drifter hourly locations and velocities, in meters per second, through time. $B$, Stick plot of drifter velocity and direction, in meters per second from true north, during the deployment. Dashed line represents drifter speeds. $C$, Stick plot of wind velocity (black), in meters per second from true north, and tidal height (blue), in meters, during the drifter deployment. Dashed line represents wind speed.
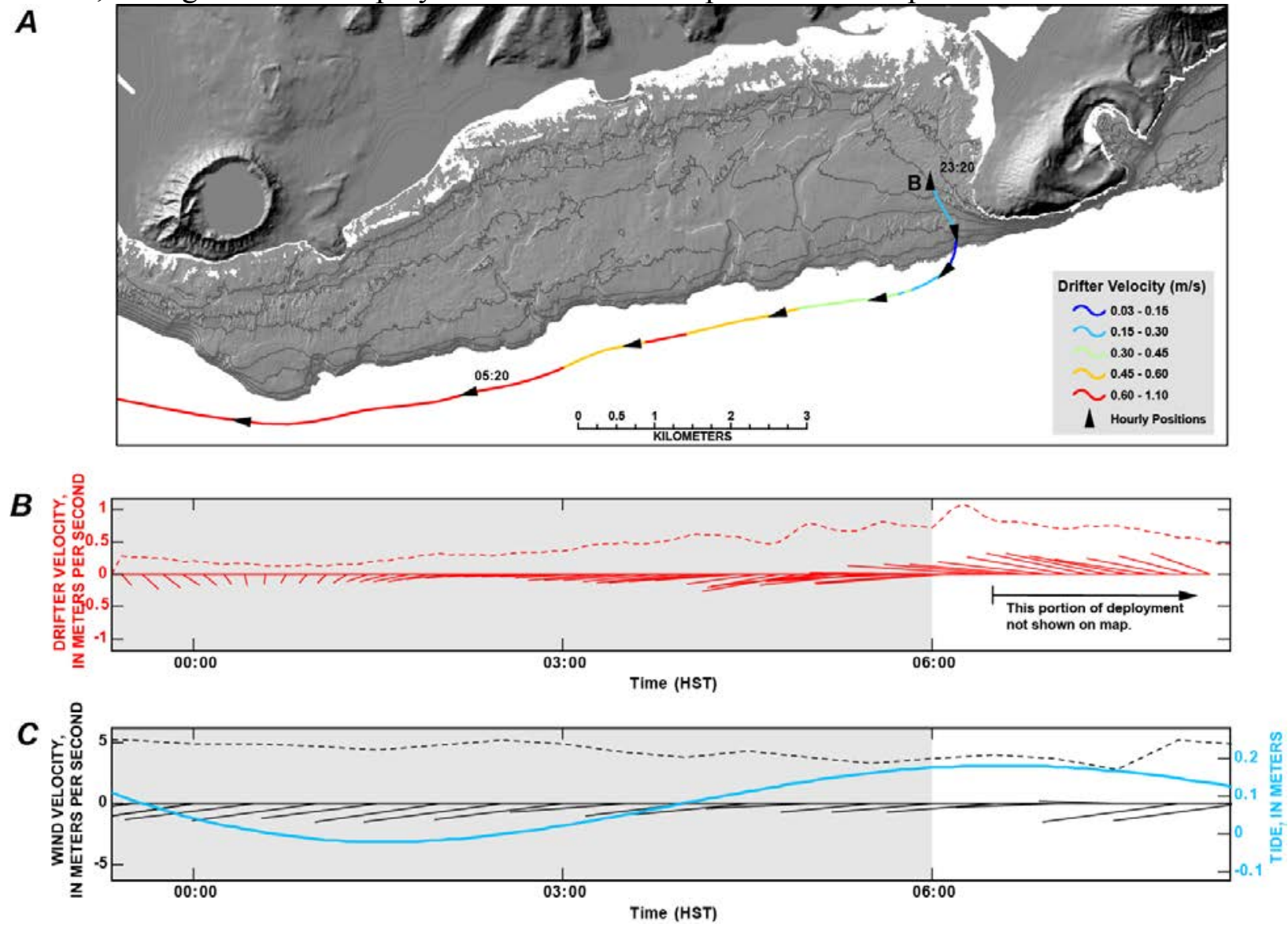